\title{
Specialty Rice Adoption, Collective Action and Marketing Channel Choice: Insights from Vietnam
}

\author{
Dissertation \\ to obtain the Ph.D. degree \\ in the International Ph. D. Program for Agricultural Sciences in Göttingen \\ (IPAG) \\ at the Faculty of Agricultural Sciences, \\ Georg-August-University Göttingen, Germany
}

\author{
presented by \\ Thai Thuy Pham \\ born in Yen Bai, Vietnam
}

Göttingen, December 2016 
D7

1. Name of supervisor: Prof. Dr. Ludwig Theuvsen

2. Name of co-supervisor: Prof. Dr. Achim Spiller

3. Name of further member of the examination committee: Prof. Dr. Oliver Mußhoff

Date of dissertation: 08. February 2017 


\section{Summary}

Trade in specialty agricultural products remains a significant foreign exchange earner for many developing countries that largely depend on the agricultural sector for their national income. With the changing consumers' tastes and preferences, production and marketing of specialty products could improve incomes of farmers particularly when such changes are accompanied by price increments for quality produce. The existing specialty varieties are bred to suit specific agro-ecological conditions and the preferences of both farmers and consumers. The cultivation of specialty varieties further appropriates the small-farm sector in most developing countries, characterized by small fragmented plots. It is therefore important to develop specialty agricultural products that are suited for small-scale agricultural production and could significantly improve the welfare of small-scale farmers.

Rice production has contributed significantly to food security and poverty reduction among rural farming households of Vietnam for the past three decades. For instance, it accounts for $30 \%$ of total value of crops, and its cultivated area has consistently increased by $1.2 \%$ annually since 1986, resulting in annual increments by 1 million tons (Appendix 5). Over the years, the Government has focused on promoting export-oriented production, resulting in substitution of hybrid varieties by indigenous and traditional varieties including specialty rice (SR). However, adverse effects of climate change, poor yields, high production costs, and rice price volatility have led to declining incomes of rice farmers. The negative effects are exacerbated by the dwindling arable land, dysfunctional marketing farmer association, and limited investment in domestic rice value chains. As a mitigation measure, the Government is promoting SR production which demand is quickly growing in Vietnam by reviving the dysfunctional farmer associations to facilitate collective action in adoption of technologies, access to markets, and marketing information.

Farmer associations play a significant role in knowledge transfer to farmers thereby facilitating adoption of SR varieties, which has been effective in minimizing pest resurgence from mixed variety cropping with variations in harvesting periods. The farmer associations also strive to overcome problems of information asymmetry thus ensuring that 
small-scale farmers fetch better prices for quality rice with brand names. With all these initiatives, several questions remain unanswered. For instance, the drivers of adoption of SR varieties and intensity of their adoption are not yet well understood. The existing literature focused on the role of collective action in facilitating adoption of hybrid and SR varieties although in most cases only qualitatively. None of the studies analyzed the effects quantitatively as we do in our study. Further, the effectiveness of such initiatives depends on farmers' preferences for marketing channels, an aspect that has not been fully studied before, at least in the SR context.

From a New Institutional Economics perspective, market imperfections result in information asymmetries that also hinder technology transfer to farmers and access to input and output markets. This is also relevant in our study particularly in the three topics related to adoption of SR, collective action and choice of marketing channels. In spite of the increasing demand for SR varieties along with other value-added products which has been highlighted in recent studies, small-scale rice farmers still lack knowledge and marketing information in order to access such high-value markets. Besides, specialty crops contribute to biodiversity and improvement of local livelihoods. Therefore, more attention should be paid to the relation between specialty variety adoption and increasing production efficiency. This dissertation combines three essays on the adoption of SR, effects of collective action on technical efficiency (TE) and farmers' choice of marketing channels. We address these topics by using cross-section data collected from 336 rice farmers in the Red River Delta (RRD) region who were interviewed between October and December 2014. The RRD is one of the major rice producing regions of Vietnam, supplying specialty and high-value rice varieties to the domestic markets including Hanoi and other cities. The question whether smallholder farmers in developing countries can be integrated successfully into high-value supply chains by adopting specialty varieties remains unanswered. Also, and particularly for SR, the drivers of adoption and intensity of SR varieties and the subsequent choice of marketing channels are not clear yet.

In the first essay, we follow the adoption behavior model based on the utility maximization criterion and adopt a two-step approach, starting with a Probit model for determinants of 
SR adoption then analyzing the intensity of adoption using a Tobit model. In general, the case of SR adoption in the RRD region contributes new insights into our understanding of the adoption decisions, especially with regard to the role of social networks and farmer group membership in rural areas. Social networks have a positive influence on SR adoption through knowledge exchange and collective decision-making in the groups. Based on the findings, we recommend strengthening farmers' networks to enhance SR production.

The second essay provides an overview of current literature on collective action and its effects on rice production efficiency in developing countries. We analyze the effects of collective action (via SR farmer associations) on TE by using a Translog stochastic model. In the first part of our results, factors such as expenditure on labor and expenditure on other costs have a statistically significant impact on the SR yield. The results show a small variation in production efficiency among the households sampled. The average TE score of SR farmers in the RRD region is $77.1 \%$. In this regard, farmers need to increase their productivity and efficiency as well as produce more SR varieties to increase their incomes from rice production.

In the third essay, we finally examine the existing rice marketing channels and farmers' choice of these channels using a multi-specification model from 280 farmers growing SR varieties. We employed a Multinomial logit model to examine the drivers of farmers' choice of marketing channels. The results reveal that even though local collectors and wholesalers dominate the rice value chain in rural areas, farmers still prefer modern marketing channels (via collective marketing channels) because of higher price and reduction in transaction costs. This has been augmented by the expansion of information sources available to farmers. 


\section{Acknowledgements}

I would like to thank my first supervisor, Prof. Dr. Ludwig Theuvsen, the advisor, Dr. Verena Otter, supportive colleagues from the GlobalFood Research Training Group (RTG 1666), the Chair of "Management in Agribusiness", and the Center for Management in International Agribusiness (CMIA) for their support and motivation during my doctoral studies. I am indebted to my thesis committee members, Prof. Dr. Achim Spiller and Prof. Dr. Oliver Mußhoff for their inputs in the review process.

I also acknowledge the financial support from the Vietnamese Government (Steering Committee of Program 165), German Research Foundation (DFG), Göttingen Graduate School of Social Sciences (GGG), and the Stiftung Fiat Panis. Without the support, I could not pursue my doctoral studies in Germany.

My fieldwork in the Red River Delta region would not have been possible without the assistance from the teams at the Hung Vuong University (HVU), Center for Agrarian Systems Research and Development (CASRAD/FCRI), and the Rural Development Center (RUDEC/IPSARD) in Vietnam. Special thanks go to Assoc. Prof. Dr. Van Cao, Dr. Thi Thanh Thuy Le, Dr. Nhat Dang Nguyen, M.A Ngoc Son Do, Dr. The Anh Dao, M.A Cong Nghiep Pham, Dr. Trong Binh Vu, Dr. Vu Quang Hoang, M.A Duc Huan Dao, M.A Sy Dat Ngo, M.A Duc Chien Dang, and the team of enumerators.

I appreciate my mother Thi Tieu Bui, my lovely wife Thi Lan Anh Nguyen, and my daughter Thu An Pham and my little son Viet Phu Pham for their full support during in entire period of my study. Thank you for showing your love and encouraging me to this point.

Special thanks go to my international and Vietnamese friends, especially HVU's team who are a part of my meaningful life in Germany.

Last but not least, I would like to thank all the survey respondents in RRD region who made this work successfully. Thank you all for your kind cooperation and time. 


\section{List of Abbreviations}

$\begin{array}{ll}\text { ASEAN } & \text { Association of Southeast Asian Nations } \\ \text { FAO } & \text { Food and Agriculture Organization of the United Nations } \\ \text { GDP } & \text { Gross Domestic Product } \\ \text { GSO } & \text { General Statistics Office (Viet Nam) } \\ \text { ha } & \text { Hectare } \\ \text { HYV } & \text { High-yielding Varieties } \\ \text { IRRI } & \text { The International Rice Research Institute } \\ \text { kg } & \text { Kilogram } \\ \text { MRD } & \text { Mekong River Delta } \\ \text { RRD } & \text { Red River Delta } \\ \text { SR } & \text { Specialty Rice } \\ \text { TE } & \text { Technical Efficiency } \\ \text { VND } & \text { Vietnamese Dong }\end{array}$




\section{List of tables}

Table 2.1. Sample Procedure by SR Adoption ................................................................... 20

Table 2.2. Descriptive statistics by SR adoption .................................................................. 23

Table 2.3. Determinants of SR adoption in the RRD region (Probit model)........................ 24

Table 2.4. Intensity of SR production in the RRD region (Tobit model) ............................. 26

Table 3.1. Yield of paddy by different regions in Vietnam (ton per ha) .............................. 35

Table 3.2. Description of selected variables ......................................................................... 40

Table 3.3. Mean estimates of variables used in the stochastic translog model...................... 41

Table 3.4. Estimates of variables used in the stochastic translog by SR farmer association

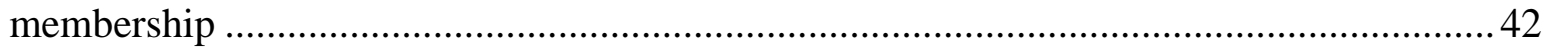

Table 3.5. Parameter estimates for the stochastic translog model for SR............................. 44

Table 3.6. Parameter estimates for the inefficiency model for SR (full sample).................. 46

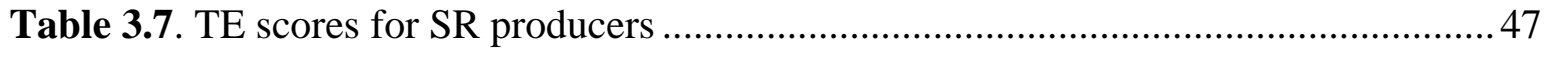

Table 4.1. Household characteristics by choice of marketing channels ...............................64

Table 4.2. Access to marketing information and the importance of marketing sources...... 65

Table 4.3. Distribution of SR output, by membership........................................................66

Table 4.4. Determinants of SR marketing channels in RRD region (Multinomial logit)....67

Table 4.5. Marketing chain performance (OLS regression) .................................................69 


\section{List of figures}

Figure 2.1. Harvested rice area, yield, production, and export quantity........................... 11

Figure 2.2. Map of the research area including Quang Ninh and Hai Duong province ...... 12

Figure 2.3. Conceptual Framework of SR Adoption................................................ 16

Figure 3.1. Paddy yield (hg per ha) in South-Eastern Asia ............................................ 34

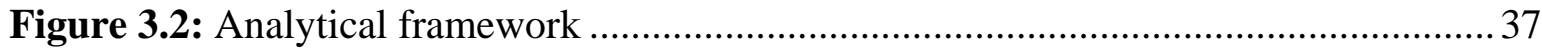

Figure 4.1. Rice marketing channel system in the Red River Delta................................ 55

Figure 4.2. Conceptual framework of farmers’ choices of marketing channels................. 60 


\title{
Definitions of Key Terminologies
}

\author{
Smallholders
}

"In favorable areas with high population densities they often cultivate less than one ha of land,” (FAO, 2004)

Specialty Rice Farmer Associations

They perform specific economic and commercial functions such as marketing strategy, the supply of inputs (upgraded seeds, organic fertilizers), training activities, technical advices, access to market information, and internal control management. All the activities are involved with specialty rice varieties in specific regions.

Collective Action

“as voluntary action taken by a group to achieve common interests”. Member can act directly on their own or through an organization (Meinzen-Dick and Di Gregorio, 2004, p.1)

Specialty Rice Varieties:

In this dissertation, the term refers to glutinous "a specialty rice, also called waxy or sweet rice. Completely breaks down during cooking” in Rice types of Southeast Asia, (USDA, 2012).

Glutinous rice plays an important role in some cultures. It is considered to be the staple food, a sweetened form for snacks, desserts, special foods or breakfast cereal (Maclean, 2002, p.8).

Specialty rice varieties are those having a good quality and regions' specific characteristics [Tran et al., 2013, page 348-356]. They include aroma rice, sticky rice, and several japonica varieties growing in some different ecological regions.

Other terms used: traditional local specialty varieties, traditional varieties, special rice varieties, indigenous varieties.

Southeast Asia

refers to Brunei, Burma, Cambodia, Indonesia, Laos, Malaysia, the Philippines, Singapore, Thailand, East Timor, and Vietnam. 


\section{Table of Contents}

Specialty Rice Adoption, Collective Action and Marketing Channel Choice: Insights from

Vietnam . $\mathrm{i}$

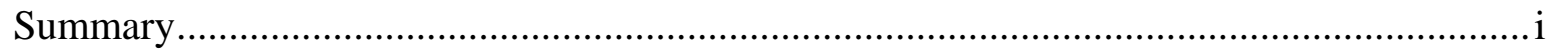

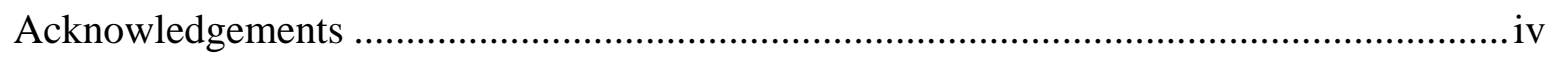

List of Abbreviations ................................................................................................. V

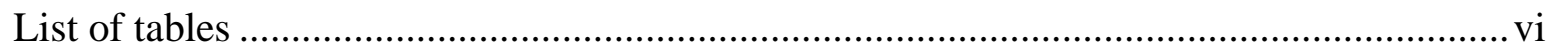

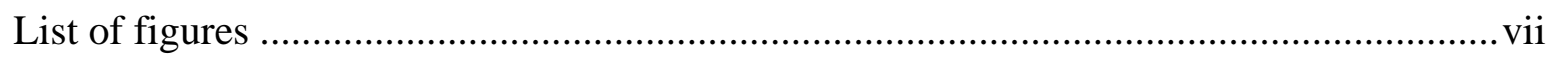

Definitions of Key Terminologies............................................................................ii

Table of Contents ...........................................................................................................

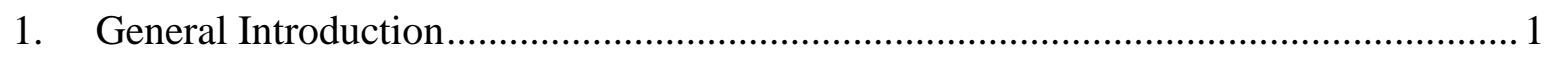

1.1. Background ....................................................................................................

1.2. Research Objectives and Dissertation Outline..................................................... 4

2. Determinant of Specialty Rice Adoption by Smallholder Farmers in the Red River

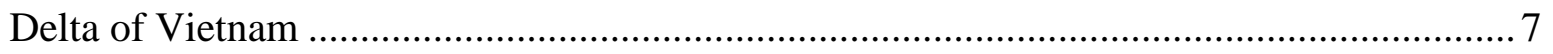

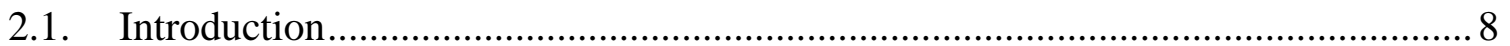

2.2. Specialty Rice Production in the Red River Delta................................................... 9

2.3. Conceptual Framework and Methodology …………………………………....... 13

2.3.1. Conceptual framework …………………….............................................. 13

2.3.2. Methodology and Estimation Strategy …………........................................... 18

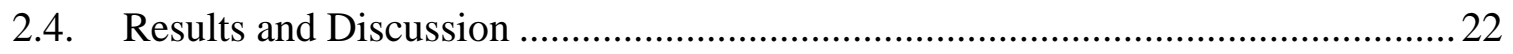

2.5. Conclusion and Policy Implication .................................................................... 27

3. Collective Action Effects on Technical Efficiency of Specialty Rice Producers in

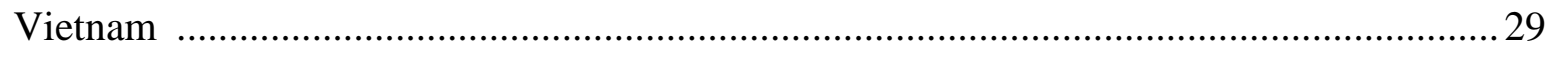

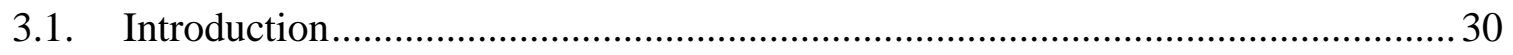

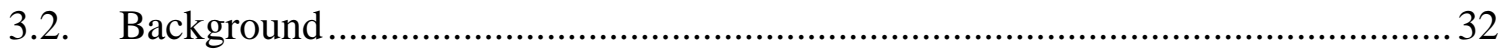

3.2.1. The Development of Collective Action within the Vietnamese Rice Sector . 32

3.2.2. Economical Characteristics of the Vietnamese rice sector.............................. 34

3.3. Data and Methodology ……………………….................................................... 36 
3.3.1. Study design and data collection .................................................................. 36

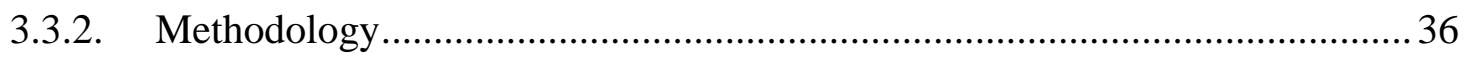

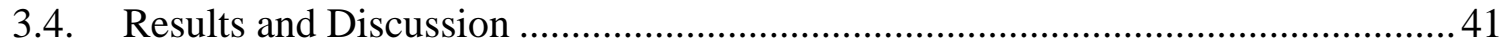

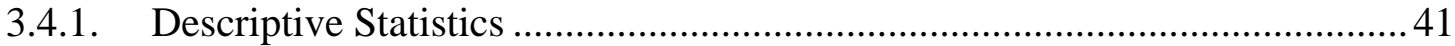

3.4.2. Parameter Estimates ..................................................................................... 43

3.5. Concluding Remarks and Policy Implications.......................................................4 47

4. Determinant of Smallholder Farmers' Choice of Marketing Channels: Evidence from

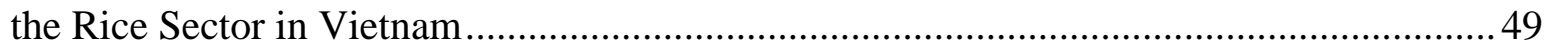

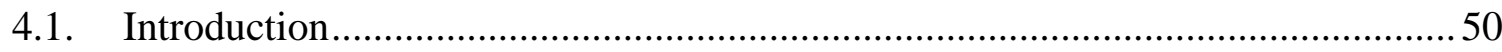

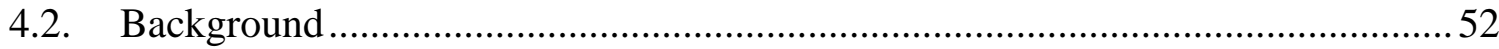

4.2.1. Complex Vietnamese Marketing Channels of Rice and their characteristics 52

4.2.2. Linking smallholder farmers to international SR rice markets.......................... 55

4.2.3. Smallholder Farmers and Collective Action …………....................................5 57

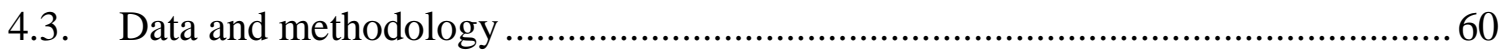

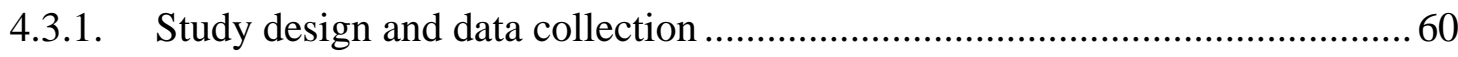

4.3.2. Methodology ............................................................................................. 61

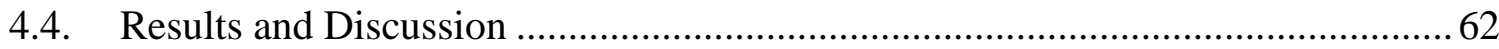

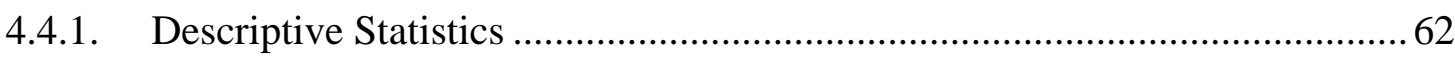

4.4.2. Determinants of Marketing Channel Choice ....................................................... 66

4.4.3. Influence of Collective Marketing on Farmers' performance ........................... 68

4.5. Concluding remarks and policy recommendations.................................................. 70

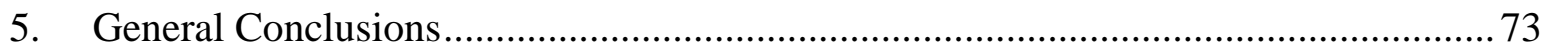

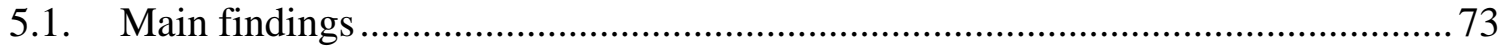

5.2. Policy Implications and Further Research …………………………………...... 75

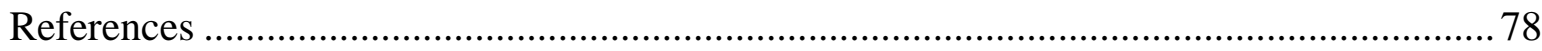

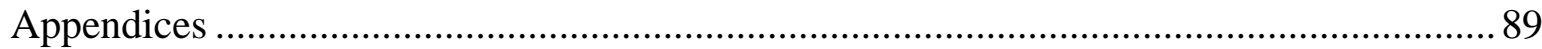

Appendix 1. The development of SR farmer association in Kinh Mon ............................. 89

Appendix 2. The development of SR farmer association in Dong Trieu ............................ 89

Appendix 3. Specialty rice harvested areas in Kinh Mon district ......................................90 
Appendix 4. Average growth rate of rice yield in Vietnam, 1976-2014 ........................90

Appendix 5. Milled rice production and consumption in Vietnam, 1986-2013..............91

Appendix 6. List of certified rice varieties in Vietnam (up to date 31.05.2013) ............91

Appendix 7. Distribution of share of SR area adopted in total cultivated rice area .........92

Appendix 8. Type of collective actions in SR production......................................... 93

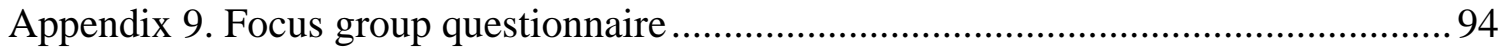

Appendix 10. Household questionnaire 2014 .......................................................... 96

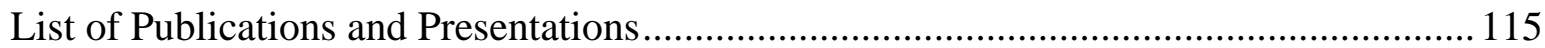

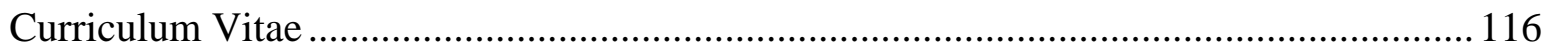




\section{General Introduction}

\subsection{Background}

It is estimated that approximately half of world population relies on rice as staple food while the share is even higher in Asia (Adjao and Staatz, 2015; FAO, 2006; Hoang and Meyers, 2015; Maclean, 2002; Yamano et al., 2016). The United Nations (2011) forecasts that by the year 2050, the global population will count over 9 billion people. Consequently the demand for rice in terms of quantity and quality is therefore expected to grow. Thus, rice production could significantly contribute to global food security by improving livelihoods of rural farming households in most developing countries in terms of income and employment (Gedara et al., 2012; Nguyen and Ferrero, 2006). In this context, changes either in prices, production, or marketing strategies of rice could have significant influences on household welfare.

Rice is the dominant crop in Vietnam, covering $87 \%$ of cultivated land, accounting for about $90 \%$ of the national cereals production (GSO, 2015) and 35\% of aggregated agricultural production value (OECD, 2015). Vietnam has been one of the major rice exporting countries for the last three decades, accounting for $6 \%$ of the world rice production. The 6 million tons exported annually from Vietnam represent 18\% of aggregate rice trade flows globally (FAO, 2006). The revolution in Vietnam in 1986 led to a shift from a centralized to a market-oriented economy, accompanied by policy reforms that have improved the agricultural sector. In 2015, the sector contributed 17\% of Gross Domestic Product (GDP) and over \$US30 billion in export value (GSO, 2015). Adjustments to policies with a focus on the rice sector are important to not only promote rice exports but also to meet the growing demand for specialty and high-quality rice occasioned by the growing Vietnamese population that currently counts for approximately 92 million people, (GSO, 2015). It is therefore important to strengthen the Vietnamese rice value chain by producing high-quality rice varieties, enhancing vertical coordination, building brand 
names, and adapting certifications to ensure its role in the agricultural sector and in the economy.

Like in other Asian countries, rice production in Vietnam faces various challenges that have led to farmers' loss of interest in its production (Maclean, 2002). For example, increased land fragmentation in the rice producing areas such as the Red River Delta (RRD) region where 90\% of farms own less than 1 ha (Maclean, 2002; OECD, 2015). Other challenges such as overuse of inputs (Yamano et al., 2016), decline in yields (Appendix 4), loss of genetic diversity, soil quality degradation, pests and diseases, water shortages and flooding (ADB, 2012), limited access to marketing information, and price volatility (ADB, 2012) should be paid more attention. Global demand for rice is increasingly shifting from low to high-quality varieties (ADB, 2012; Minot and Goletti, 2000). Especially, the demand for traditional rice varieties (with special flavors and high quality) is also increasing due to income growth and changes in tastes and preferences of the growing population particularly in Southeast Asia, and Europe according to Chaudhary (2003) and the FAO (2006).

To address the challenges of rice production globally, interventions aimed at preserving and expanding production of traditional rice varieties could facilitate adoption of SR and highquality rice farming and marketing. This is augmented by public awareness of the importance of rice for food security and livelihood improvement as seen in the development of geographical indication (GI) and collective mark for specialty products. Such certified traditional rice brands are more beneficial to farmers due to lower production costs, higher price premiums, better adaptation to ecological conditions compared to high yielding varieties (Chaudhary, 2003). Furthermore, modern rice variety such as golden rice has been recently adopted in Philippines could be a good way to reduce of vitamin A deficiency in many other rice countries (Dawe et al., 2002).

Agricultural sector reforms in many countries developed and strengthened farmers organizations and cooperatives (collective action) to improve agricultural production and marketing through knowledge transfer, adoption of technologies, input purchases that lower transaction costs, and higher prices from collective bargaining (Barham and Chitemi, 2009; 
Fischer and Qaim, 2012, 2014; Latynskiy and Berger, 2016; Markelova et al., 2009; Moustier et al., 2010; Shiferaw et al., 2011). Also in Vietnam, collective action helps rice farmers to actively participate in the SR value chain using their own brand names (Moustier et al., 2010) and simultaneously helps to preserve the country's cultural heritage by respecting the region specificity of particular agricultural products.

Vietnam has been in the top five largest exporters of rice in the world after of the economic policy reforms since 1986. Most of Vietnamese rice exported is low and medium quality targeting markets in Africa, Indonesia, China and the Philippines. Due to the low quality level it receives lower prices than the rice of similar varieties stemming from the main competitor Thailand (Maclean, 2002). Nielsen (2003) suggests improving quality of rice and promoting SR production to access niche markets in the European Union, Japan and the United States. In addition, the Vietnamese domestic rice market needs to be strengthened and upgraded through development of regional and local rice brand names to meet the growing domestic and niche markets. Thus, the promotion of these rice varieties for sustainability of Vietnamese rice sector seems crucial (Rutsaert and Demont, 2015).

During the last three decades, many political regulations have been introduced in order to support the rice sector in Vietnam. The regulations include for instance: price support measures targeting a profit of 30\% for rice farmers, payment based on paddy area in 2012, participation of the private sector in export rice industry, upgrading rice varieties, constructing irrigation systems (OECD, 2015; Tran and Dinh, 2015; Tran and Vu, 2016). The two most important policies are to maintain 3.8 million ha of paddy land through monetary direct support (the Decree No. 42/2012/ND-CP dated May 11, 2012) in order to target food security (Resolution 63/NQ-CP dated December 23, 2009). They are recognized as crucial for the sustainable development of the rice sector in Vietnam (The Vietnamese Government, 2009, 2012).

Currently, the Vietnamese rice brands include; “Certificated Marks” from the Government, “GIs”, “Collective Marks”, among other provincial and local brand names (Appendix 6). 
The branding policies are expected to overcome the marketing and production challenges as well as facilitate access to high-value markets (The Vietnamese Government, 2015), with a target of $20 \%$ of the rice export volume under the Vietnamese rice brands by 2020 , and $50 \%$ by 2030 of which 30\% are supposed to be of high quality, aroma rice and SR varieties (The Vietnamese Government, 2015). Developing the whole rice value chain, building the production areas, applying appropriate technologies related to seeds, processing, storage, packaging, distribution, and marketing are considered as main solutions to reach these targets.

Overall, this dissertation contributes to the international scientific literature based on three aspects: Firstly, understanding the role of social networks in exploring the drivers and intensity of SR adoption; secondly, conducting a study based on quantitative methods following on early production stages to marketing processes of smallholder farmers; thirdly, exploring how marketing information and collective action affect smallholder farmers' choice of non-traditional marketing channels. These issues are very relevant to developing countries context for the long-term development of SR varieties as well as other specialty products (Chaudhary, 2003; Dawe et al., 2002).

\subsection{Research Objectives and Dissertation Outline}

Demand for specialty and high-quality rice varieties is growing in Vietnam but also in international markets. In Vietnam, these varieties are now considered cash crops mainly targeting high-value markets just as the case of Basmati rice in India or Jasmine rice in Thailand. Hence, an ambitious intellectual property program has been developed to promote local and under-utilized specialty products with brand names and also to enhance biodiversity. This plan is augmented by investments in rural infrastructure including irrigation and transportation which are important pillars to link farmers to markets.

Despite the importance of SR and the investments in its production, SR varieties have not been widely adopted yet (Dao and Pham, 2013). Furthermore, there are limited empirical studies on the drivers and intensity of SR adoption, and the role of collective action in 
enhancing its production. Further, it is not clear what influences farmers' choice of marketing channels for these varieties. Existing studies are mainly qualitative in nature (Bui et al., 2009; Dao and Pham, 2013; Le, 2009; Moustier et al., 2010) which do not answer such empirical questions. The lack of marketing information, weak social networks, land use limitation, and unstable productivities might be possible reasons for the existence of SR adoption gap. In many rural areas, smallholder farmers are often less powerful when bargaining with their trading partners in SR rice value chain, and they even do not know the consumers' preference about SR products' characteristics.

This dissertation focuses on the linkages between three topics: SR adoption, collective action (via SR farmer associations), and choice of marketing channels. These combined topics are relatively unexplored in current literature, especially in the Vietnamese context in the light of aforementioned bottlenecks in rice production, particularly SR varieties.

This dissertation addresses these gaps by answering the following three main questions:

1. What are the drivers and intensity of SR adoption in Vietnam?

2. To what extent does collective action influence TE of rice farmers?

3. What are the determinants of farmers' choice of marketing channels for SR varieties?

For analyzing, we use cross-section data collected in 2014 from 336 farmers in the RRD region of Vietnam using a structured questionnaire and also use semi-structured questionnaire for focus group discussions with farmers (Appendices 9 and 10).

Several New Institutional Economics concepts unravel in our study, particularly associated with development, governance, and growth of agricultural markets in developing countries. They include: property rights in terms of access to arable land, GIs and collective marks certificated marks or other certifications (e.g., GlobalGAP, organic) to reinforce fair pricing for quality products; collective action and social capital ingrained in the SR farmers associations to reduce transaction costs thereby influencing farmers' choice of marketing channels, and improve farm performance. For instance, Kersting and Wollni (2012) found 
the establishment of new institutional arrangements between smallholder farmers and other stakeholders has been encouraged by the adoption of GlobalGAP group certification in the fruit and vegetable in Thailand. In case of Basmati rice in Northern India, Jena and Grote (2012) recommended that the establishment of producer organizations could promote the production and export of Basmati rice with GIs. This certification will protect producers with a premium price and ensure the certified quality products to end consumers.

Several variables were used to capture these aspects in the various regression specifications (e.g., Probit, Tobit, Multinomial logit, OLS) as shown in the essays. The role of collective action via SR farmer association is underscored in the adoption of SR varieties and determination of marketing channel choice among rural farmers of Vietnam. With growing populations, it is one of the promising pathways to enhancing SR production, productivity of fragmented lands, and improving rural livelihoods in many developing countries, particularly in Vietnam.

In addition to the introductory chapter, the rest of the dissertation is organized as follows:

Chapter 2 presents the first essay entitled "Determinant of Specialty Rice Adoption by Smallholder Farmers in the Red River Delta of Vietnam”. In this chapter, we used a Probit model to analyze the drivers of SR adoption and a Tobit model to determine the intensity of adoption.

Chapter 3 presents the second essay entitled "Collective Action Effects on Technical Efficiency of Specialty Rice Producers in Vietnam". We analyze the effects of collective action on TE of SR farmers using a Stochastic frontier analysis.

Chapter 4 entails the third essay namely "Determinant of Smallholder Farmers' Marketing Choice: Evidence from the Rice Sector in Vietnam”. The determinants of farmers' choice of marketing channels were examined using a Multinomial logit model whereas linear regression is used to examine the effect of collective marketing on farmers’ performance.

The last chapter concludes by summarizing our main findings, study implications, limitations, and suggestions for further research. 


\title{
2. Determinant of Specialty Rice Adoption by Smallholder Farmers in the Red River Delta of Vietnam ${ }^{1}$
}

\begin{abstract}
Vietnam is one of the major rice exporters experiencing growing increase in domestic and international demands for SR. Still, SR production can be difficult with lack of a trademark, asset investment, and collective action. Empirical enquiry into this situation remains limited. We address this gap by analyzing determinants and intensity of SR adoption in Vietnam by using a sample of 336 farmers from RRD region who were interviewed between October and December 2014. We follow the adoption behavior model based on the utility maximization criterion and adopt a two-step approach, starting with a Probit model for determinants of SR adoption before analyzing the intensity of adoption using a Tobit model. The selected independent variables included: households’ sociodemographic and economic characteristics. Probit model estimates indicate that for every additional "sao" (equals to $360 \mathrm{~m}^{2}$ ) and network size the probability of SR adoption increases by $5 \%$ (p-value<0.01). Distance to the nearest market and number of laborers are however significant and negatively effecting the probability of SR adoption. Overall, 50\% of the probability of SR adoption is explained by the selected independent variables. Tobit model estimates show that group membership (such as in agricultural cooperatives, farmer's union, women's union, etc.) and possession of a cart increase the share of land allocation to SR production by $3.4 \%$ and $7.8 \%$ respectively. The model explains $14.8 \%$ of the variation of the share of SR planted area and the LR test equals to 44.4 (p-value $<0.01$ ) rejecting the null-hypothesis at least one of the predictors' regression coefficients is not equal to zero. Policy adjustments towards improving infrastructure, building social networks, promoting farmer groups, and land reforms would accelerate SR adoption and, thus, the rural economy in Vietnam.
\end{abstract}

\footnotetext{
${ }^{1}$ This paper is a joint work with Dr. The Anh Dao at the Center for Agrarian systems research and development (CASRAD), Field Crops Research Institute (FCRI) and Prof. Dr. Ludwig Theuvsen at the Department of Agricultural Economics and Rural Development, University of Goettingen.
} 


\subsection{Introduction}

Rice production plays a key role in the agricultural development of many developing countries, especially in the rice economies of the Association of Southeast Asian Nations (ASEAN) (ADB, 2012; IRRI, 2003). Billions of people around the world rely on rice as a staple food (Coxhead et al., 2012; Giraud, 2013; Muthayya et al., 2014); as a result, focusing on rice production helps to improve food security issues and stabilize economies (Minot and Goletti, 2000). Furthermore, rice production is a crucial source of export earnings for rice economies like Thailand and Vietnam. Due to increasing consumer wealth coupled with economic growth, demands for rice in terms of food quality and safety is now a global issue (Chaudhary, 2003; Giraud, 2013). Smallholder farmers could raise their incomes by producing SR varieties that are unique in terms of quality and increase their potential for selling to high-value markets. Globally, aromatic rice- one of the most important SR varieties which accounts for $10-15 \%$ of world trade, sells at $50 \%$ higher price than common rice (Chaudhary, 2003). Producing SR varieties, thus, might be a good tool for reducing poverty and improving livelihoods, and has indeed made great contributions to these ends in many developing countries, such as India, Pakistan, Thailand, the Philippines, and Vietnam (Chaudhary, 2003; Giraud, 2013; Moustier et al., 2010). In addition, there are increasing opportunities for local varieties to reach specialized and high-value markets. As a result, more attention should be paid to the adoption of SR varieties.

The growth of high-value agricultural and specialty markets presents both opportunities and challenges for smallholder farmers in many developing countries (Gulati et al., 2005). On one hand, this trend creates opportunities for small farmers to raise their income. Wollni and Zeller (2007), for example, find that farmers who participate in specialty coffee markets achieve higher prices than farmers delivering to traditional markets. On the other hand, such markets are often associated with higher costs of participation and stricter requirements concerning food safety and quality control than are traditional ones. In many cases, high-value markets do not necessarily refer to international or export markets, as domestic or regional markets still offer potential for specialty agricultural products. 
With a significant increase in GDP per capita by an annual $12.73 \%^{2}$ from $2010-2013$, the demand for SR varieties in Vietnam has risen over time. In accordance, the Government has implemented ambitious programs to protect and develop the many kinds of specialty agricultural products with intellectual property rights such as geographical indication (GI) label and collective mark. SR is, thus, a relevant case study for adoption of high-quality agricultural products in developing countries. Moustier et al. (2010) find that there is a raising demand for SR within specialized marketing channels in Vietnam. This is a positive development, as a good way to stabilize the country's SR market.

We fill this gap by introducing a conceptual framework and an ongoing empirical research on the adoption of innovation in agricultural production related to social networks (Bandiera and Rasul, 2006, Hoang et al., 2006; Matuschke and Qaim, 2009; Moser and Barrett, 2006). We hypothesize that farmers are more likely to adopt SR when other farmers in their network have adopted SR through sharing experiences and knowledge. To estimate the effect of social networks on individual adoption decision of SR production we use the network size as the main measurement at the village level (Wellman, 1979). Network size is measured by: how many close farmers a household can rely upon should it face financial problems or other hardship. The aim of this paper is to analyze determinants and intensity of SR adoption in Vietnam. For this study, any farmer that does not cultivate SR seed variety was not considered an adopter of SR production.

\subsection{Specialty Rice Production in the Red River Delta}

The term "specialty rice" in the international market is currently used to refer to Jasmine rice from Thailand and Basmati rice from either India or Pakistan. Chaudhary (2003) defines varieties of SR as: “... those which are not common”. SR is unique in terms of aroma, kernel color, or chemical composition, of which aroma is the most important criterion in classing rice grain quality. Jamora and Cramon-Taubadel (2012) categorize

\footnotetext{
${ }^{2}$ Calculation from the World Bank data (http://data.worldbank.org/indicator/NY.GDP.PCAP.CD).
} 
aromatic and glutinous rice as specialty items in particular regions (India and Pakistan, ASEAN). The higher SR price is another indicator which used to compare it with normal rice (Moustier et al., 2010; Ngokkuen and Grote, 2012).

Following Chaudhary (2003), the major groups of SR varieties worldwide are: aromatic rice, color rice, red rice, black rice, soft rice, glutinous or waxy rice, nutritional quality rice, and organic rice. Glutinous rice is defined by the International Organization of Standardization as special varieties of rice (Oryza sativa L. glutinosa) the kernels of which have a white and opaque appearance. The starch of glutinous rice consists almost entirely of amylopectin. It has a tendency to stick together after cooking (ISO, 2011).

In our paper, we use the term "specialty rice” to refer to glutinous varieties, sometimes also called "sticky," “sweet," or "waxy” rice (Chaudhary, 2003), which grow mainly in Southeast and East Asia, e.g., in Laos, Thailand, and Vietnam. In our study, SR primarily focuses on national and regional markets in order to meet local consumers' demands and preferences. In essence, glutinous rice is a traditional variety that has been upgraded in terms of seed quality due to development programs in recent years (Jaenicke et al., 2010). For this study, any farmer that does not cultivate SR seed variety was not considered an adopter of SR production.

Vietnam is the second largest rice exporting country in the world behind Thailand (FAO, 2006). The vast majority of rice exported is low and medium quality, making the Vietnamese rice cheaper than that of rivals (Jamora and Cramon-Taubadel, 2012; Nguyen and Baldeo, 2006; Nielsen, 2003). The percentage of glutinous rice in total export volume in 2011 was approximately 3\% (Giraud, 2013); to be competitive in the rice market, the country must focus on the development of high-quality and SR varieties (Nguyen and Baldeo, 2006).

The harvested rice area, production, export volume, and yield per ha in Vietnam (19862013) are shown in Figure 2.1. The harvested area and rice yield had increased gradually during the period of 1986-2013. This is also due to the process of renovation or "Doi moi" that was implemented in the late 1980s. In 2013, 7.9 million ha were harvested with an average yield of 5.57 tons per ha, producing approximately 44 million tons of rice 
(FAOSTAT, 2015; GSO, 2014). Export volume was around 6.5 million tons per year by 2015.

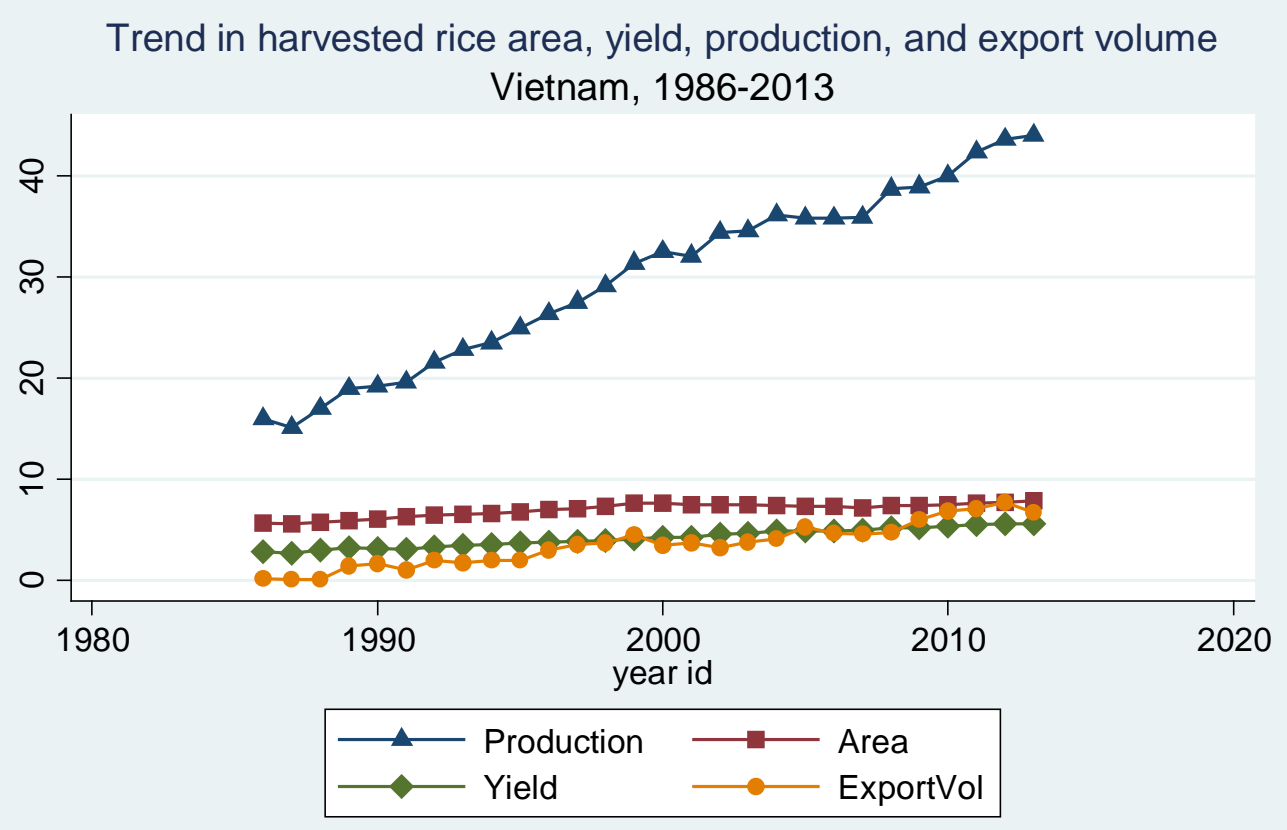

Source: FAOSTAT, last accessed May 2015 \& FAO rice market monitor volume XVII issue No.1 Harvested area in mil.ha, yield in tons/ha, production in mil.tons, and export volume in mil.tons

Figure 2.1. Harvested rice area, yield, production, and export quantity

Source: (FAOSTAT, 2015; GSO, 2014)

To foster high-quality rice varieties and commercialize SR production for domestic and export markets, several policies have already been implemented in support of small farmers, such as the branding of Vietnamese rice, the reduction of pre- and post-harvest losses, the attention to climate change (e.g. climate change adaptation and low carbon emission measures in rice production), and improvement of soil fertility (Nielsen, 2003).

Income growth, urbanization, and other socioeconomic transformations have affected the consumption of and preferences for foodstuffs, including rice. Overall, rice consumption per capita in Vietnam has been on a downward trend since 2000. Consumers are buying less of it while simultaneously demanding higher quality products. This trend leads farmers to produce more high-quality rice for urban consumers. Indeed, the majority of Vietnamese people do not use glutinous rice as a main staple food, but they often use it for special 
occasions, such as making cakes or ceremonial dishes, or as a valuable gift that farmers give to their relatives. SR has thus essentially become a very important source of cash income for rice farmers.

The RRD has a long history of rice production, and, as one of two main rice production regions in Vietnam, most of its agricultural land is allocated to rice cultivation. The region has numerous rice varieties, many of which are protected by the Vietnamese Government under a collective mark, certified mark, and or a geographical indication (Appendix 6). Among the SR varieties, Hoa Vang glutinous rice is the most popular for its quality. Grown mainly in Northern Vietnam (e.g., Hai Duong, Quang Ninh, Thai Binh, and Bac Ninh provinces), it is a long-term variety with a growing time of around 145-150 days. Farmers sell the majority of their surplus rice to the domestic traditional markets in Hanoi, Hai Phong, and Quang Ninh, the RRD’s three largest cities. In this study, Quang Ninh and Hai Duong province were purposely selected as research areas (See Figure 2.2).

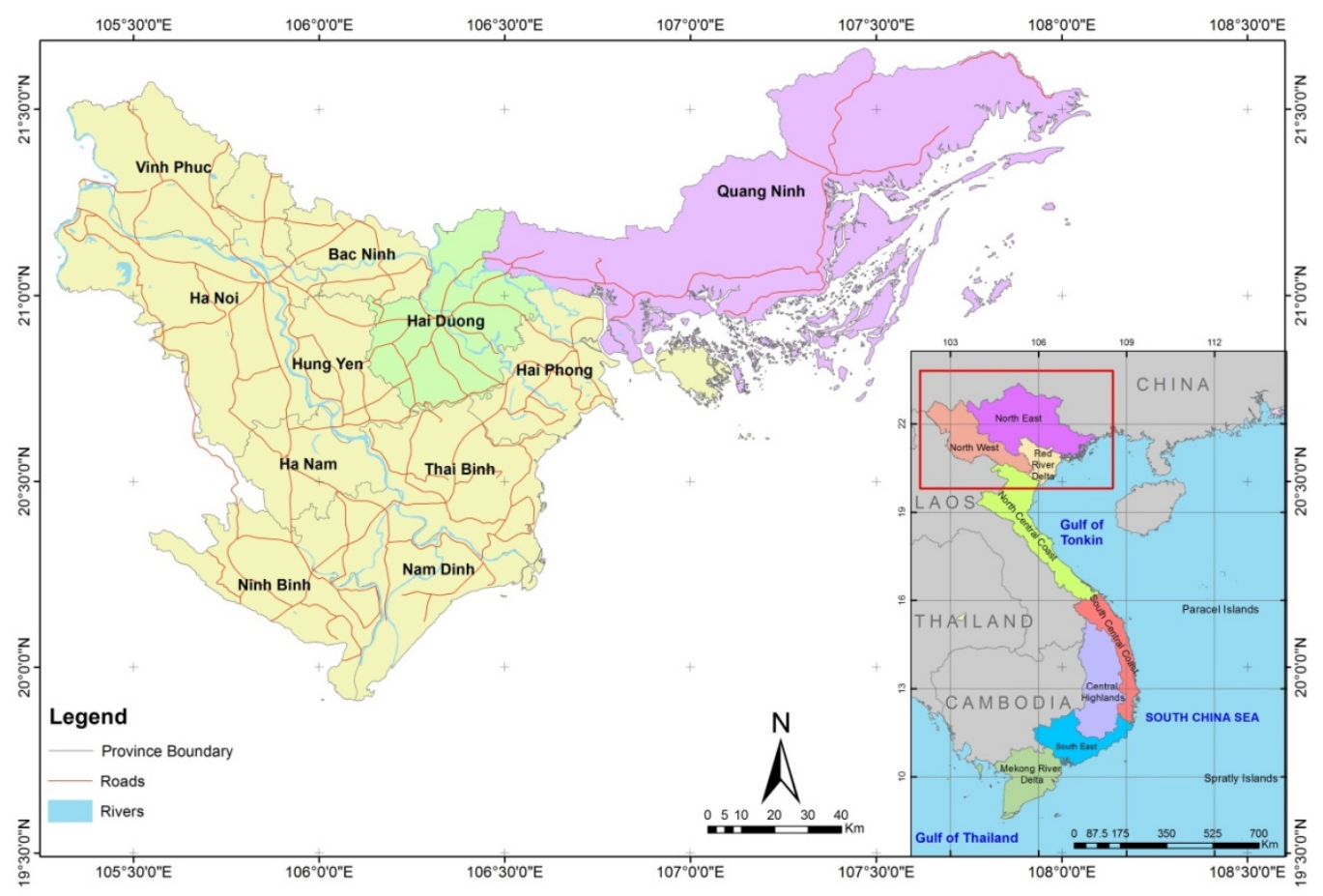

Figure 2.2. Map of the research area including Quang Ninh and Hai Duong province Source: http://www.arcgis.com/features/index.html 
Some previous research (Jaenicke et al., 2010; Moustier et al., 2010) has noted the area of SR production has decreased in recent years due to the impacts of industrialization and urbanization. The "Hoa Vang” glutinous rice in particular must compete with ordinary varieties in the region. Jaenicke et al. (2010) find that the area of SR before 1986 was much higher than at present. To meet the consumers' current demands, the Government has tried to expand the SR area by investing more in infrastructure, improvement of traditional seeds, and new cultivation practices.

\subsection{Conceptual Framework and Methodology}

\subsubsection{Conceptual framework}

In the conceptual framework, we follow the model of adoption behavior put forth by Rahm and Huffman (1984). In their model, farmers' adoption decisions are assumed to be based on the objective of utility maximization. In our case, the decision by small farmers to adopt SR is covered by the household adoption model; their goal is to maximize the utility (U), which is obtained from the SR adoption but depends on both vector $\mathrm{R}_{\mathrm{i}}$ of farm and farmer characteristics, and vector $A_{i}$ of the attributes associated with SR adoption. The utility function will be described in the following section.

This conceptual framework is well-known in the existing literature (Feder et al., 1982) and has been applied in recent adoption studies (Adedeji et al., 2013; Kijima and Sserunkuuma, 2013; Ngokkuen and Grote, 2012; Wollni and Zeller, 2007). For instance, Adedeji et al. (2013) and Kijima et al. (2008) look at the adoption of new rice varieties in Nigeria and Uganda, respectively. In addition, the conceptual framework refers to the diversification strategy of small farms in developing countries where, due to land constraints, farmers attempt to diversify their activities in order to improve their standard of living.

In previous studies, the adoption of rice varieties has been analyzed via a focus on highyielding varieties (HYV) and new technologies in rice sector. In recent decades, many kinds of traditional varieties have been replaced by HYVs in order to ensure food security and caloric intake (IRRI, 2003; Mottaleb et al., 2015; Nguyen and Baldeo, 2006). Lin (1991) found that education has a positive effect on the F1 hybrid rice varieties in China. In the 
case of Bangladesh, Mottaleb et al. (2015) noted that a number of factors (e.g., loan facilities, road access, irrigation facilities, and seed dealers) have significant influence on the adoption of hybrid varieties.

The conceptual framework and literature review suggest that a number of institutional and circumstantial factors significantly influence the adoption process, including farm experience (Kijima and Sserunkuuma, 2013), access to extension services (Moser and Barrett, 2006; Ngokkuen and Grote, 2012), capital resources (Feder et al., 1982), and the social network (Matuschke and Qaim, 2009; Moser and Barrett, 2006).

For our study, we divided the analysis of SR adoption into two separate parts. The first part is the decision to adopt SR, which may be influenced by individual or household specific factors such as risks, profitability, social networks, and farmer/farm characteristics (see Figure 2.3). In the second part, rice farmers decide how much cultivated land they allocate to SR production, a decision that also depends on their attitude towards their diversification strategy and those factors mentioned above.

In addition, individual factors that influence SR production are divided into two main groups. Following these chosen variables, we analyze those factors with a positive and negative impact on the participation of small farmers in the SR production.

SR may have dramatically higher price and returns but may also be more sensitive to flooding and diseases. Market price fluctuation is another common source of uncertainty, though the relationship between domestic price and farm gate price. Many rice farmers prefer approaches with lower average returns but more reliability to approaches with higher returns, and more risks. Adoption of SR varieties may be seen as risky, as they are longterm varieties. In RRD region, SR is considered a cash crop, so in this case farm gate price in the long-term can be one factor that influences SR adoption.

Adoption of any agricultural innovation such as technology adoption or improved varieties adoption depends on the profitability. Profitability of SR production is influenced by economic and social factors, for instance farm gate price, production costs, productivity, farm characteristics, social network, and farm characteristics. Previous studies highlights 
the profitability of any production systems is much more a function of farm management skills than lower input costs (Batie and Taylor, 1989).

\section{Measuring Network Size}

An analysis of social network and social capital has been widely applied in agricultural innovation studies (Hoang et al., 2006; Maertens and Barrett, 2013; Marsden, 1990; Matuschke and Qaim, 2009; Wossen et al., 2015). Smallholder farmers often use social networks to obtain information, solve problems, exchange knowledge, and gain social support. Matuschke and Qaim (2009) found that social networks play a crucial role in the decision to adopt innovation as well as the adoption intensity of hybrid seed in India. Recently, Wossen et al. (2015) highlighted that social capital significantly influences technology adoption.

There are many aspects with which to measure social networks, including network size, network density, centrality and centralization, tie strength, and network range (Marsden, 1990). In this paper, we use "network size" as the primary measurement of a social network and as such assume that farmers rely on their network to exchange social and economic information. Social interaction may influence rice farmers' decision to produce SR, as Moser and Barrett (2006) found that learning in social networks significantly influences the system of rice intensification adoption in Madagascar. In the same vein, Hoang et al. (2006) found that neighborhood networks significantly influenced the adoption of innovation in Northern Vietnam.

We applied the following method in order to analyze network size (Wellman, 1979): first, respondents were asked about the number of close farmers in the village they regularly talk to and share information with about SR production. Second, we asked two hypothetical questions regarding financial and social support in the case of a lack of money or a suddenly occurring hardship in order to clarify how many people in their network. For each question, we asked respondents how many close farmers in the village are willing to support them or offer immediate help. Those questions helped to determine the network 
size of the small rice farmers' interviewed. We assume that the larger network a rice farmer has, the higher the probability of SR adoption.

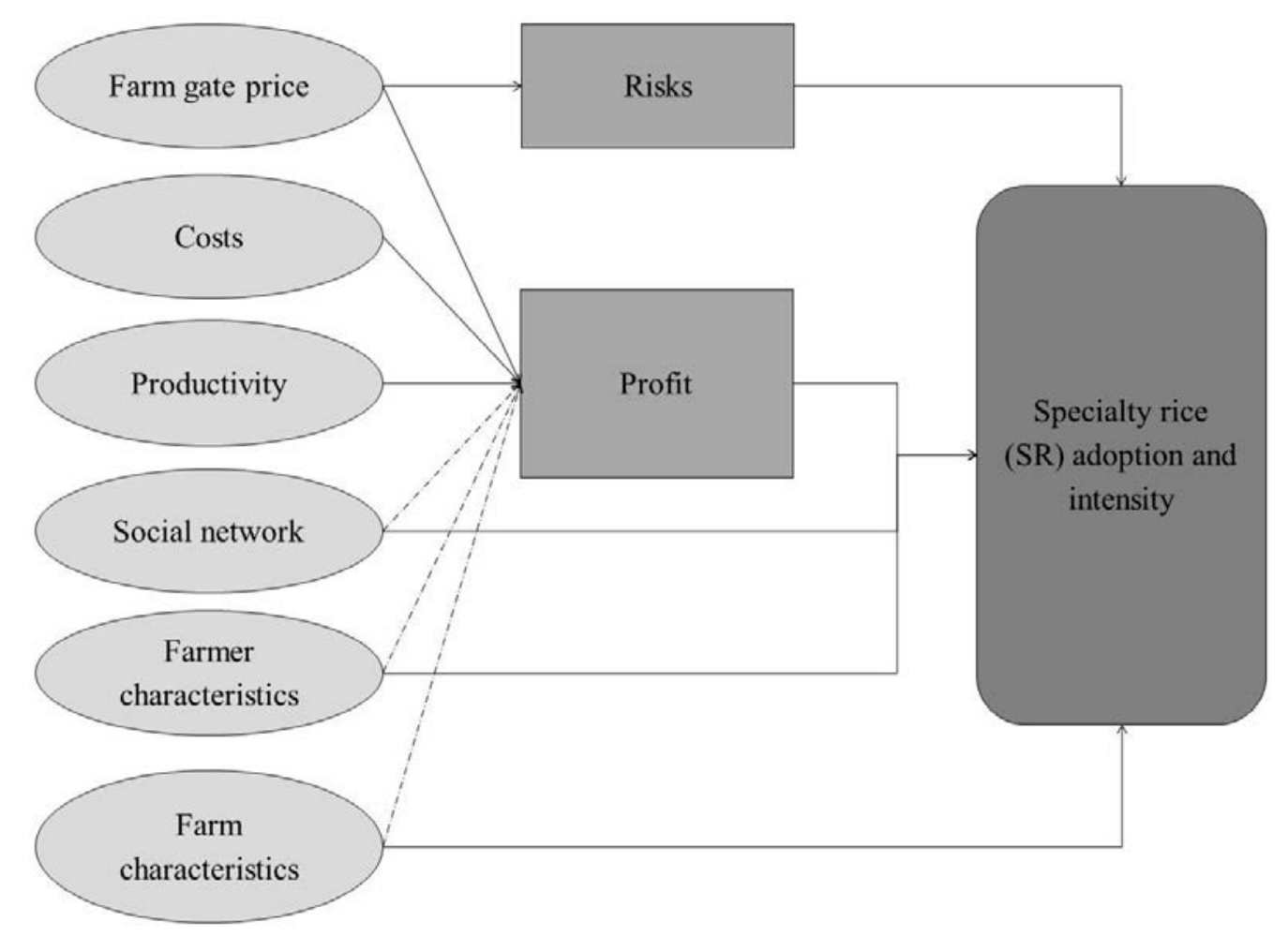

Figure 2.3. Conceptual Framework of SR Adoption

Source: Authors’ illustration

\section{Demographic characteristics:}

The age of the household head may have an impact on farmers' decision to produce SR. Adedeji et al. (2013) found that in Nigeria, a younger male household head is more likely to adopt an improved rice variety than an older one. Older farmers, however, have a higher probability of continuing to produce SR, as their particular variety is related to traditional techniques since they have more experience in growing rice than younger farmers do.

Gender of the household head is included as a dummy variable to account for possible gender effects on SR adoption. Ngokkuen and Grote (2012) find that male farmers are more likely to adopt GI certification than females in Thailand. Males are expected to be more 
likely to adopt and expand their share of SR compared to female headed households; presumably, they have a better understanding of how to produce SR relative to females or they have less risk aversion.

The number of individuals aged 16 to 60 in the household plays an important role in the decision to adopt SR, as the higher the number of productive laborers, the more likely they are to adopt SR (Kijima et al., 2008; Kijima and Sserunkuuma, 2013). However, households with many members may prefer diversifying non-farm activities in order to generate higher incomes and grow other rice varieties or crops.

Off-farm: This variable explains whether the head of the household worked outside agriculture. On the one hand, doing so helps the household by providing additional source of income that can be used to invest in SR production; on the other hand, it might increase the opportunity cost of family labor, especially during the harvesting season (as we observed, SR production is more labor-intensive than are ordinary varieties).

Cultivated land represents the total agricultural land cultivated in one year period as measured by various formal or informal land transactions. Farmers who have more land are more likely to adopt improved varieties than are small-scale rice farmers. A growing body of literature on the impact land size has on improved technology has found significant positive correlation between land and the decision to adopt (Adedeji et al., 2013; Moser and Barrett, 2006; Ngokkuen and Grote, 2012).

Owned land is a continuous variable used as a proxy to indicate a household's wealth. Feder et al. (1982) found that larger and wealthier farmers are more likely to adopt innovation and do so earlier than others.

Participation in groups/organizations is measured by how many farmer groups/organization at the commune level that household participated in (e.g., agricultural cooperative, farmer union, women union, youth union, etc.). Being a member in farmer groups is expected to have a positive influence on SR production as such farmers raise their awareness of SR and come into contact with other group members knowledgeable of SR. By participating, farmers can easily gain access to extension or credit services and can adopt improved 
technology; Ngokkuen and Grote (2012), for example, found that being a cooperative member had a significant positive impact on GI adoption in the case of Jasmine rice in Thailand. We assume the more groups/organizations farmers are involved in the more likely they are to adopt SR.

Other factors: The distance to the nearest local market may be one factor that has a negative impact on SR adoption. It is assumed that the further the household's proximity to the market, the higher are transportation costs and the lower is access to market information (Kijima and Sserunkuuma, 2013), and so less likely to adopt.

Another factor that may have an impact on farmers' decision is the occurrence of external catastrophes such as disasters, floods, storms, and droughts, as SR production always takes on some external environment-based risk (Feder et al., 1982). Because SR is a long-term variety, there are often more risks in production in comparison with ordinary or normal rice varieties in the same region.

\subsubsection{Methodology and Estimation Strategy}

\section{A. Household survey}

This survey was conducted in Hai Duong and Quang Ninh provinces, a famous area in the RRD region for SR production (see map). In Hai Duong, the proportion of the population living in rural areas was $77.90 \%$ in 2013; the proportion of the labor force aged 15 or older in the rural area was $79.20 \%, 39.5 \%$ of which were involved in agriculture. The gross domestic product per capita ${ }^{3}$ was 34,560,000VND (US\$1,645). For this study, we selected Kinh Mon district, since it is famous for Hoa Vang glutinous rice production (Appendix 3). Generally, the district only accounts for $10 \%$ of total planted area of paddy in Hai Duong province (HSO, 2013), but has the largest SR area in Hai Duong province. The improved seeds were first time introduced in 2006 under the Government's support.

\footnotetext{
${ }^{3}$ Vietnam currency, at current prices in 2013; and exchange rate: US\$1 $=21,009$ VND
} 
In Quang Ninh, the proportion of the population living in rural areas was $38.30 \%$ in 2013, while the proportion of the labor force aged 15 or older accounted for $76.90 \%$ of the total rural population. The gross domestic product per capita was 58,674,000VND (US\$2,789). We selected Dong Trieu district for this study, as it is the second largest district in terms of planted paddy area with the highest paddy productivity (approximately 5.8 ton per ha) from 2005-2013 (QSO, 2013). We found it is interesting to focus on these two provinces in terms of difference in their rural populations' structure $(77.90 \%$ and $38.30 \%$ in Hai Duong and Quang Ninh respectively). Furthermore, the two provinces are different in term of potential urban markets.

From the two selected districts, we randomly chose four communes in each, then selected two villages in each commune, including SR and non-SR production. There were totally 16 villages in our sample. All data were achieved during the 2013/2014 cropping season which included the winter of 2013 and the summer of 2014. Our survey was conducted between October and December 2014; here, we randomly chose rice farmers on the village level who do and do not produce SR based on the list of villagers received from the local authorities.

We carried out the survey by using a structured questionnaire, including different modules (e.g., on household characteristics, tenure and farm production, non-farm income, social networks, consumption and expenditure) and conducted direct interviews with individual farmers. The total number of observations is 336 households. Consequently, we used all interviewed households in the analysis and classification of their characteristics in order to determine the factors influencing their decision to adopt SR production.

The sample is divided into two categories: farmers who produce SR $(\mathrm{N} 1=276)$ as treatment group and farmers who do not produce SR (N2=60) as control group. In both groups, male head household dominated (more than 60\%). Since we particularly focused on SR production, the treatment group is over represented. 
Table 2.1. Sample Procedure by SR Adoption

\begin{tabular}{ccccc}
\hline & & Total & \multicolumn{2}{c}{ By gender of the household head } \\
Male & Female \\
\hline \multirow{2}{*}{ SR adoption } & Yes & 276 & 183 & 93 \\
& No & 60 & 42 & 18 \\
\hline
\end{tabular}

Source: Household survey data, 2014

\section{B. Focus Group Discussion}

Focus group is now applied widely to identify farmers' preferences and needs that will assist in the long-term development in the rural areas. Ideally, the focus group method is based on participants' opinion expression (Brent et al., 1991; Johnston et al., 1995). The method was used as an explanatory tool to discover farmers' opinion about SR varieties and main reasons to non-adopter SR.

Focus group discussion was applied shortly after the household survey. We invited a small number of 15 participants from the non-adopter group. The selection of group participants was typically purposive based more on convenience. Data were collected from the interaction between members of the group using a focus group questionnaire (Appendix 9). They discussed main reasons to not produce SR in the villages and ranked the reasons in order of importance. This method traced more carefully the cognitive and social processes that influenced respondents' comprehension of survey questions and their subsequent responses. Each participant freely gave his or her opinion and exchanged the information with other participants. All in all, the method helped to illustrate survey findings and clarify survey results.

\section{Estimation Strategy}

Random sampling procedure was used to sample 336 farmers from the RRD region who were interviewed using a structured questionnaire. We follow the adoption behavior model put forth by Rahm and Huffman (1984) that based on the utility maximization 
criterion and adopt a two-step approach, starting with a Probit model for determinants of SR adoption before analyzing the intensity of adoption using a Tobit model.

Rice farmer's utility function $(U)$ :

$$
U_{j i}=\alpha_{j} F_{i}\left(R_{i}, A_{i}\right)+\varepsilon_{j i} \text {, where } j=0,1 \text { and } 1 ; i=1,2, \ldots, n
$$

Rice farmers are assumed to choose rice variety that gives them the largest utility; in other words, $\mathrm{U}_{1 \mathrm{i}}$ must be greater than $\mathrm{U}_{\mathrm{oi}}$ when the $\mathrm{i}^{\text {th }}$ farmer chooses to adopt an SR variety over ordinary one.

$$
D_{i}=\left\{\begin{array}{l}
1 \text { if } U_{1 i}>U_{0 i} S R \text { variety is adopted } \\
0 \text { if } U_{1 i}<U_{0 i} \text { normal rice is adopted and replaces } S R \text { variety }
\end{array}\right.
$$

\section{Modelling SR adoption}

Firstly, rice farmers decided whether or not to produce SR. Using a simple Probit model (equation 2.3), we divided the sample into two groups (those that do produce SR and do not), based on the assumption that other conditions remain the same. Secondly, we examined the intensity of use (i.e., how much cultivated land is planted for SR) based on a Tobit model (equation 2.4 and 2.5).

Probit model: decision to produce SR (adoption decision)

$$
y_{1 i}^{*}=X_{1 i}^{\prime} \beta_{1}+\beta_{2} * \text { network size }+v_{i}
$$

Tobit model: how much land is planted for SR (intensity of use)

$$
\begin{gathered}
y_{2 i}^{*}=X_{2 i}^{\prime} \beta_{2}+\mu_{i} \\
y_{2 i}=\left\{\begin{array}{l}
y_{2 i}^{*}, \text { if } X_{2 i}^{\prime} \beta_{2}+\mu_{i}>0 \\
0, \text { other wise }
\end{array}\right.
\end{gathered}
$$

Where the SR adopter is a dummy variable indicating whether the farmer adopted SR, and $X_{i}$ is a vector of explanatory variables expected to affect the adoption decision. In the Tobit model, we used both outcome variables $\left(y_{2 i}^{*}\right)$, that is, the share of the SR area adopted in the total cultivated rice area (\%) and the total planted SR area $\left(\mathrm{m}^{2}\right)$ during the winter season of 2013. $\mathrm{X}_{1 \mathrm{i}}$ is the vector of explanatory variables for the adoption of SR; while 
$\mathrm{X}_{2 \mathrm{i}}$ is the vector of illustrative variables for the level of SR adoption in the RRD region. The two error terms $\mathrm{v}_{\mathrm{i}}$ and $\mu_{\mathrm{i}}$ are expected independent and normally distributed with $\mathrm{v}_{\mathrm{i}} \approx$ $\mathrm{N}(0,1) ; \mu_{\mathrm{i}} \approx \mathrm{N}\left(0, \sigma^{2}\right)$.

\subsection{Results and Discussion}

We divided the sample into two groups, 276 adopters who had at least one plot growing SR and 60 non-adopters of SR production. In terms of gender of the household head, 70\% were male and 30\% were female. The main characteristics of rice households are given in Table 2.2. Overall, SR adopters had higher gross income and per capita incomes than nonadopters.

SR adopters tended to have older household heads; in our study, the SR farmers were on average 53 years old and had extensive experience in growing rice. On average, their mean years of growing rice amount to 29.5 as compared to 8.4 years in the non-adopter group. However, SR farmers are significantly less educated as their counterparts. For instance, about $30 \%$ of household heads of adopter group had a high school degree as opposed to 43.3\% of non-adopter farmers. Farmers who adopted SR had better access to extension (73.2\%) in comparison with farmers producing ordinary rice varieties (56.7\%). Another significant difference relates to access to credit. Among adopter group, about $44 \%$ of households obtained financial services as compared to roughly $62 \%$ in non-adopter group.

Regarding the agricultural area, the first important finding is that the farm size of farmhousehold in our sample is dominated by small farms. More than $90 \%$ of the respondents cultivate rice on 0.5 ha or less. There is a difference in average owned land and cultivated land between the two groups. SR adopters also had more land area and a higher number of plots than did non-adopters. As we observed, rice farmers preferred to diversify of varieties in order to produce for many purposes (e.g. own consumption, providing for their relatives in urban areas, or earning cash). The descriptive results from Table 1 show that SR farmers have a larger network size (about 7.4) than do other rice farmers (3.0). The number of farmers who are able to provide financial and social support is significantly different. 
Table 2.2. Descriptive statistics by SR adoption

\begin{tabular}{|c|c|c|c|}
\hline Variable description & $\begin{array}{l}\text { Adopters } \\
\left(N_{1}=276\right)\end{array}$ & $\begin{array}{l}\text { non-Adopters } \\
\left(N_{2}=60\right)\end{array}$ & Differences \\
\hline \multicolumn{4}{|l|}{ Household characteristics } \\
\hline Age of household head (in years) & 53.192 & 47.083 & $6.109^{* * *}$ \\
\hline Age of household head squared & 2,921.141 & 2,294.983 & $626.158^{* * *}$ \\
\hline High school degree (dummy) & 0.304 & 0.433 & $-0.129^{*}$ \\
\hline \multicolumn{4}{|l|}{ Social capital \& network size } \\
\hline Access to extension (dummy) & 0.732 & 0.567 & $0.165^{* *}$ \\
\hline Access to credit (dummy) & 0.438 & 0.617 & $-0.178^{* *}$ \\
\hline Experience in growing rice (in years) & 29.507 & 8.367 & $21.141^{* * *}$ \\
\hline Network size (number) & 7.391 & 3.067 & $4.325^{* * *}$ \\
\hline Number of local organizations involved & 3.014 & 2.583 & $0.431^{* *}$ \\
\hline \multicolumn{4}{|l|}{ Farm characteristics } \\
\hline Number of plots & 5.580 & 4.050 & $1.530^{* * *}$ \\
\hline Owned land $\left(\mathrm{m}^{2}\right)$ & $2,255.830$ & $1,626.060$ & $629.770^{* * *}$ \\
\hline Owned land 5 years ago $\left(\mathrm{m}^{2}\right)$ & $2,411.452$ & $1,831.740$ & $579.712^{* * *}$ \\
\hline Cultivated land 2013-2014 $\left(\mathrm{m}^{2}\right)$ & $2,952.404$ & $1,730.460$ & $1,221.944^{* * *}$ \\
\hline Total planted SR $\left(\mathrm{m}^{2}\right)$ & $1,202.622$ & 0.000 & $1,202.622^{* * *}$ \\
\hline \multicolumn{4}{|l|}{ Farm wealth } \\
\hline Owns cart (dummy) & 0.572 & 0.400 & $0.172^{* *}$ \\
\hline \multicolumn{4}{|l|}{ Farm performance } \\
\hline Total paddy (kg) & $2,617.496$ & $1,595.550$ & $1,021.946^{* * *}$ \\
\hline Gross household income ('000VND) & $119,655.850$ & $88,059.916$ & $31,595.935^{* * *}$ \\
\hline $\begin{array}{l}\text { Gross household income per capita } \\
\text { ('000VND) }\end{array}$ & $31,752.864$ & $22,686.987$ & $9,065.877^{* * *}$ \\
\hline Food expenditure per month ('000VND) & $2,897.053$ & $2,582.557$ & $314.496^{* *}$ \\
\hline
\end{tabular}

Significant at ${ }^{*} p<0.10,{ }^{* *} p<0.05,{ }^{* * *} p<0.01$;

Productive labors were calculated as household members who are over 16 and less than 60 years old.

Source: Authors' calculations

The empirical results of SR adoption are presented in table 2.3. Model 1 gives the outcomes of a probit model that we estimated without including network size which is the main variable of interest in our study. There are several explanatory variables that are expected to have an effect on rice farmers' decisions for or against to SR adoption. We also calculated 
the average marginal effects (AME) of each model that may help to understand the magnitude of the effects of each explanatory variable on the probability of SR adoption.

Some of the explanatory variables are statistically significant. The regression results show that cultivated land, experience of growing rice, and possession of a two-wheel tractor have a significant positive influence on SR adoption. However, the number of productive laborers and the distance to the nearest local market has significant negative effects on SR adoption. Other factors such as age and gender of household head, access to credit are insignificant, and groups' participation is contrary to our expectations.

Table 2.3. Determinants of SR adoption in the RRD region (Probit model)

\begin{tabular}{lllll}
\hline & Model 1 & & Model 2 & \\
\hline Variables & Coef & AME & Coef & AME \\
\hline Productive laborers (number) & $-0.20249^{* *}$ & $-.0388212^{* *}$ & $-0.23646^{*}$ & $-.0323541^{*}$ \\
& $(0.09357)$ & $(.0174539)$ & $(0.13438)$ & $(.0165626)$ \\
Experience in growing rice (years) & $0.02808^{*}$ & $.0053836^{*}$ & $0.03652^{*}$ & $.0049974^{*}$ \\
& $(0.01677)$ & $(.0031386)$ & $(0.02202)$ & $(.0027884)$ \\
Cultivated land $\left(\mathrm{m}^{2}\right)$ & $0.00072^{* * *}$ & $.0001377^{* * *}$ & $0.00066^{* * *}$ & $.0000901^{* * *}$ \\
& $(0.00015)$ & $(.0000261)$ & $(0.00023)$ & $(.0000255)$ \\
Network size & - & - & $0.38516^{* * *}$ & $.0526995^{* * *}$ \\
& - & - & $(0.07204)$ & $(.0054914)$ \\
Distance to the nearest market & $-0.28306^{* * *}$ & - & $-0.24043^{*}$ & $-.0328968^{*}$ \\
(km) & & $.0542681^{* * *}$ & & \\
& $(0.10471)$ & $(.0192525)$ & $(0.13916)$ & $(.0177005)$ \\
Owns cart (dummy) & $0.40289^{* *}$ & $.0772418^{* *}$ & 0.24571 & .0328968 \\
& $(0.19035)$ & $(.0347947)$ & $(0.22449)$ & $(.0290792)$ \\
Constant & $-1.16474^{*}$ & & $-2.58229^{* * *}$ & \\
& $(0.70618)$ & & $(0.82337)$ & \\
Observations & 336 & & 336 & \\
Wald statistic & 51.87 & & 67.40 & \\
Prob $>$ chi2 & 0.0000 & & 0.0000 & \\
Pseudo R-squared & 0.2659 & & 0.4909 & \\
\hline
\end{tabular}

Notes: Robust standard errors in parentheses; ${ }^{* * *} \mathrm{p}<0.01,{ }^{* *} \mathrm{p}<0.05,{ }^{*} \mathrm{p}<0.1$

Source: Authors' calculations 
Cultivated land has a significant and positive influence on the likelihood of producing SR at a $1 \%$ significance level. Due to urbanization trend in the two provinces, more young farmers get out of agriculture to create their own businesses or work in the industry sector, leaving their land to relatives or neighbors for cultivation. On average, if the cultivated land increases by $1 \mathrm{~m}^{2}$, the probability of the household's adoption of SR increases by $0.014 \%$ equivalent to a $5 \%$ rise in probability per additional local unit of land in the RRD region. $\left(1 \mathrm{sao}=360 \mathrm{~m}^{2}\right)$. If farmer households possess a cart, their probability to adopt SR increases by $7.7 \%$.

In model 2, we added the network size in the adoption model. All other factors held constant, our main variable of interest- network size increases the probability of SR adoption by $5.3 \%$ if rice farmers have one more person in their network. The more close neighbors who produce SR a rice farmer has, the more likely it is that a farmer adopts SR. Based on social network relations farmers can learn from others and influence each other by collective decision. Similarly, if rice farmers gained experience one year in growing rice, their probability of adoption SR increases by $0.5 \%$.

The number of productive laborers in the family has a negative and significant effect on SR adoption, a result which supports the trend of increasing opportunities for finding off-farm income in the region. Households with more laborers are more likely to leave agriculture to find a job in the industry sector in order to diversify and raise their income. As expected, distance to the nearest market as a proxy for the transaction cost variable has a negative and significant effect on the probability of SR adoption at $10 \%$. With an unit increase (one kilometer) in distance, the probability of SR adoption decrease by 3.3\%. It means that households closer to the nearest market are more likely to adopt SR than ones living farther away. This could be explained by the chance to get more information, training activities, and the higher probability to get access to market.

After analyzing the factors that influence the decision to adopt, we explore the factors that affect the intensity of use (Table 2.4). To do so, we use two dependent variables: the share 
of SR area adopted in the total cultivated rice area (\%) (Appendix 7) and the planted SR area $\left(\mathrm{m}^{2}\right)$. These variables were captured in the winter paddy season in 2014 .

The number of groups that rice farmers are involved in and whether they have a two-wheel tractor have a significant influence on the area allocated to SR. The number of groups a household is involved in has a positive effect on the intensity of SR adoption. For additional group a rice farmer is involved in, such increases the planted SR area by $139 \mathrm{~m}^{2}$. The coefficient of the total cultivated area also shows a significantly positive influence on the intensity of SR, indicating that if rice farmers expand their agricultural land use, they are more likely to increase the SR planted area.

Table 2.4. Intensity of SR production in the RRD region (Tobit model)

\begin{tabular}{lll}
\hline Variable & $\begin{array}{l}\text { Share of SR } \\
\text { planted area }(\%)\end{array}$ & $\begin{array}{l}\text { Area planted to } \\
\text { SR }\left(\mathrm{m}^{2}\right)\end{array}$ \\
\hline Productive laborers (number) & $-0.03675^{* *}$ & $-92.35597^{*}$ \\
& $(0.01558)$ & $(48.17506)$ \\
Total cultivated area $\left(\mathrm{m}^{2}\right)$ & $0.00003^{* *}$ & $0.40791^{* * *}$ \\
Group-membership (number) & $(0.00001)$ & $(0.03100)$ \\
& $0.03418^{* *}$ & $139.56671^{* * *}$ \\
Owns cart (dummy) & $(0.01497)$ & $(46.20060)$ \\
& $0.07811^{* *}$ & $232.32657^{* *}$ \\
Constant & $(0.03513)$ & $(108.76310)$ \\
& 0.03001 & $-875.79790^{*}$ \\
Observations & $(0.14617)$ & $(452.66687)$ \\
LR chi2 (10) & 336 & 336 \\
Pseudo R-squared $(\%)$ & $44.39 * * *$ & $162.20 * * *$ \\
\hline
\end{tabular}

Standard errors in parentheses; ${ }^{* * *} \mathrm{p}<0.01,{ }^{* *} \mathrm{p}<0.05,{ }^{*} \mathrm{p}<0.1$

Source: Authors' calculations

The Likelihood Ratio (LR) Chi-Square tests demonstrate that the Tobit model is appropriate (Wooldridge, 2010). In comparison with the results from the Probit regression, experience in growing rice and the distance to the nearest local market are not statistically different from zero, indicating they do not appear to influence the intensity of SR. Our main finding is various factors have an influence on farmers' decision to adopt SR production and the intensity of adoption. It was also found that social networks have a close 
relationship with SR production that is, a farmer's individual decision to produce SR is also influenced by his/her neighbors in the village. This is in line with findings from previous studies showing that social networks has been played a significant role in technology adoption (Bandiera and Rasul, 2006; Maertens and Barrett, 2013; Matuschke and Qaim, 2009).

The number of farmer groups the household is involved in has a positive influence on the SR area adopted. Group participation helps to expand farmers' SR area through common effort and peer learning. This is relevant in the case of Vietnam where most of households participated in at least one farmer group. Being member in farmer groups, household is provided with agricultural training, extension services, market information, and other subsidies (Kijima and Sserunkuuma, 2013; Moustier et al., 2010). In addition to the regression results, the descriptive statistics show that wealthier rice farmers with more land and possession of a two-wheel tractor tend to be more likely to adopt SR. These findings resonate with past studies that found significant difference between cultivated land in the adoption of improved technology (Adedeji et al., 2013). It means that farmers that operate on relatively lager scale level are discovered to have higher adoption level. It should be kept in mind that almost all farmers in our sample are small-scale. Limited availability of suitable cultivated land may be a potential constraint to SR adoption.

\subsection{Conclusion and Policy Implication}

All in all, the case of SR adoption in the RRD region contributed new insights into our understanding of adoption decisions, especially the role of social network and group membership in rural areas. We find that cultivated area and network size have a positive and significant influence on households' likelihood to produce SR. Additional experience tends to increase adoption SR varieties, and long distance to the nearest local market tends to reduce it. However, some basic farmers' characteristics did not have a significant effect on the probability and intensity of adoption SR. The findings of this study have several important implications for policy making. As expected, in order to expand the area of SR, authorities need to invest more in helping small farmers to build their networks through 
training activities. Promoting SR production must address the specialized markets where the product is given particular consideration in terms of quality, origin, and quality control. Thus, policy-makers should focus more on addressing and strengthening new marketing channels for specialty products by providing credit or loan to SR farmer associations and supporting market information.

Social network has a positive influence on SR adoption because of it makes knowledge exchange and collective decision-making possible. Based on the findings, this study will help foster the production of SR among smallholder farmers by building up individuals' network size. More importantly, SR farmers should be involved in activities such as: interactions, meetings, events, and other common projects. In addition, a land reform policy will help to increase SR production in the RRD region, for instance implementing of land consolidation program and creating land market. Therefore, it contributes to the overall policy regarding the development of specialty agricultural products in Vietnam's rural areas. 


\title{
3. Collective Action Effects on Technical Efficiency of Specialty Rice Producers in Vietnam ${ }^{4}$
}

\begin{abstract}
s
Rice is an important staple and a foreign exchange earner in Vietnam. Increasing productivity and efficiency of its production could therefore reduce poverty and food insecurity among rural households. Despite an extensive literature on determinants of efficiency and productivity in rice production, empirical work on effects of collective action remains limited. The study addresses this gap by analyzing effects of collective action on technical efficiency from a sample of 280 specialty rice farmers randomly selected from the Red River Delta. The stochastic frontier model results show an average technical efficiency score of $77 \%$, implying that specialty rice production could potentially be increased by $30 \%$ without raising the current input levels. The average technical efficiency of specialty rice producers ranges between $50.4 \%$ and $97.8 \%$. The members of specialty rice farmers' association record efficiency score of $79.4 \%$ compared to $73.5 \%$ of non-members. Inefficiency model estimates show positive significant effect of membership on farmers' technical efficiency of 9.4\% $(\mathrm{p}<0.01)$. This might be due to the fact that many members do not fully comply with the technical protocols for rice production outlined by the farmers associations. Other farm and farmer characteristics also positively or negatively influence technical efficiency. Developing and facilitating operations of specialty rice farmer associations is critical to improve technical efficiency in rice production. Detailed policy recommendations are discussed.
\end{abstract}

\footnotetext{
${ }^{4}$ This paper is a joint work with Dr. Verena Otter and Prof. Dr. Ludwig Theuvsen at the Department of Agricultural Economics and Rural Development, University of Goettingen.
} 


\subsection{Introduction}

Rice is the staple food to more than a half of the world's population (Gross and Zhao, 2014), with significant consumption observed in developing countries in Africa and Asia (GRiSP, 2013). These countries are experiencing significant reduction of arable land due to population growth, environmental degradation, dynamic climatic conditions, and overuse of natural resources, crop chemicals. Expansion of acreage under rice production is therefore constrained given also the existing competition with other major crops (e.g. corn, soybean, and wheat). Increasing rice productivity is considered to be a suitable tool besides adoption of new technologies and expansion of agricultural markets for poverty reduction and food security. In this regard, there is a need for empirical research on improving productivity and technical efficiency (TE) in order to achieve sustainable growth in rice production worldwide (Mottaleb et al., 2015).

There is a growing body of literature on productivity and efficiency analysis in crop production (Abdul-Salam and Phimister, 2016; Ali and Flinn, 1989; Battese and Broca, 1997; Rahman, 2003; Rao et al., 2012; Wollni and Brümmer, 2012) and the drivers including sociodemographic farm and farmers' characteristics. For instance, farmers' educational level has been found having a positive effect on TE (Abdulai and Eberlin, 2001; Ali and Flinn, 1989; Coelli and Battese, 1996; Tan et al., 2010; Ulimwengu and Badiane, 2010; Wadud and White, 2000). Rao et al. (2012) also mention that female suppliers of supermarket channels are technically more efficient than male suppliers. Larger farms are also more likely to have significantly higher TEs than smaller ones as found in some studies (Coelli and Battese ${ }^{5}$, 1996; Tan et al., 2010) in exception of the studies by Rahman et al. (2009) and Wollni and Brümmer (2012) in Thailand and Costa Rica. Abdul-Salam and Phimister (2016) find that increasing farmers’ ability to access information leading to increase production efficiency of smallholder farmers in Uganda.

\footnotetext{
${ }^{5}$ Coelli and Battese, 1996 also mentioned that their result contradicted the claim which is frequently made for developing country's agriculture that smaller farms tend to be more efficient in production than larger ones.
} 
Collective action was greatly supported by governments and NGOs in many developing and transition countries in order to gain economies of scales. Meinzen-Dick and Di Gregorio (2004) define collective action as voluntary action taken by a group to achieve common interests. Collective action helps farmers overcome several production and marketing constraints caused by the small-scale of operation as well as limited access to credit and information. As one of the few studies, Wollni and Brümmer (2012) find that farmers' membership to coffee cooperatives influenced farm-specific efficiency in the case of specialty coffee production in Costa Rica. This is greatly supported by a study from Bavorova et al. (2005) who found that agricultural association membership in Czech agriculture has a significant positive impact on farm's performance through the services offered by the associations such as trainings and consultancy services. In case of rice production in Sri Lanka, Gedara et al. (2012) found that farmer organizations membership and active participation have significantly influence on TE among rice producers. However, until today there is no study proofing this effect also for the Vietnamese rice sector.

Rice is a major agricultural export commodity for Vietnam, with an average annual export of 6.5 million tons (USDA, 2015). The country records the highest rice productivity at 5.8 ton per ha among the Associations of Southeast Asian Nations (ASEAN). However, a huge loss of rice output still persists (Hoang and Yabe, 2012; Huynh and Yabe, 2011; Kompas, 2002; Vu, 2012). Previous empirical studies on rice production have analyzed various issues. For instance, the impact of environmental factors on profit efficiency in the RRD region (Hoang and Yabe, 2012), the impact of vocational training (Ulimwengu and Badiane, 2010), the determinants of rice farmers' TE (Huynh and Yabe, 2011; Vu, 2012), the effect of market reforms on productivity and efficiency (Kompas, 2002). To the best of our knowledge, any quantitative study exists on the effect of collective action on TE in rice production, especially high-quality and specialty varieties in Vietnam. Understanding these provides a basis for policy-makers to develop long-term agricultural strategies with regard to specialized agricultural products sold to specialized markets through farmer associations with is nowadays generally gaining increasing. 
Chapter 3 - Collective Action Effects on Technical Efficiency of Specialty Rice Producers

This study aims to examine the effects of collective action (via SR farmers association) on TE using a translog stochastic model. A parametric approach has been used to analyze primary data collected from 280 SR producers which were randomly selected in the RRD and personally interviewed in the year 2014. The paper is organized as follows: Section 3.2 provides an overview of previous academic literature on the Vietnamese rice sector and thereafter presents insights in Vietnam's rice sector. In section 3.3 materials and methods are shown. Section 3.4 presents the results of the productivity and TE analysis before drawing conclusions and policy recommendations in section 3.5.

\subsection{Background}

\subsubsection{The Development of Collective Action within the Vietnamese Rice Sector}

From the late 1950s to 1986, in Vietnam most of agricultural products were produced through cooperatives. Pingali and Vo (1992) emphasized that Vietnam had a failure experience on the process of collectivization. This led to the reduction of productivity and efficiency in the Vietnamese crop production and caused a lack of staples and food insecurity. Nowadays, the Vietnamese Government has implemented policies to support a new form of agricultural cooperatives and farmer associations. These organizations are considered to be a new institution in Vietnamese rural areas.

Frédéric and Dao (2005) illustrated how farmer associations were established in the RRD region. Firstly, SR farmers were organized into small groups of producers under local governments support. Secondly, they themselves established SR farmer associations in order to expand their land size, identify their unique production area, meet the technical protocol, and to increase access to the urban market. In the very beginning of production processes, quality seeds were selected carefully under the support of geneticists. Rice farmers were asked for the most typical characteristics of the specialty varieties in the region and worked with the geneticists for choosing the best quality seeds. This was considered to be a population-based breeding method that would facilitate interactions between researchers, SR farmers, and their communities. 
Dao and Pham (2013) showed the model of development of SR varieties based on the demand of local communities in the RRD region. Through participation in this new production model the average of cultivated area of SR increased from 0.08 to 0.13 ha per household. In addition, SR yield was improved from 115 to $133 \mathrm{~kg}$ per sao ${ }^{6}$ (equals to 3.2 to 3.7 ton per ha) and members in SR farmer associations received higher incomes than non-members. Therefore, members in SR associations have to follow a collective production protocol (Jaenicke et al., 2010). This technical protocol was designed based on a survey of groups of experienced SR farmers in the region. After several discussions, the document has been used to train potential members in order to meet the basic requirements of the associations. During the production period, SR farmer associations run their internal quality control systems that helped to clarify the quality of members' products after harvesting.

Overall, the studies mentioned have indicated that collective action has a role in improving production techniques and yield in Vietnam with the background of land constraints in cultivated land. Of course, members must comply with the associations' regulations and technical processes. In this regard, there are also studies describing failures in the practical application of collective activities among SR association members. Bui et al. (2009), found that $80 \%$ of members in Hai Duong province used the associations' microbial fertilizer but only 50\% sold their paddies to collective processing and distribution center. Another problem mentioned by Le (2009) is the low rate (10.34\%) of members fully respecting the technical protocol of the associations even though $70.69 \%$ of them are using the association's seed and approximately 60\% are selling paddies to the association. More detailed information regarding collective actions in SR production of farmer associations in the RRD region is shown in the Appendix 8.

However, a body of literature exists on collective action in the SR sector in Vietnam, the authors of these studies used qualitative methods (value chain approach, in-depth survey, expert interviews), that could not provide a quantification of the effects of collective action

\footnotetext{
${ }^{6}$ Sao: is a traditional unit of land area in the Northern Vietnam. It equals to $360 \mathrm{~m}^{2}$.
} 
on the efficiency and productivity of SR production. In this regard, the effect of collective action on TE still needs to be identified which is the objective of this study.

\subsubsection{Economical Characteristics of the Vietnamese rice sector}

The rice yield observed for different countries in Southeast Asia in a fifteen-year period (from 2000 to 2014) is shown in Figure 1 (FAOSTAT, 2015). In this period, Vietnamese rice yield has been increased by 2.2\% annually. Yield grew from 4.24 tons per ha in the year 2000 to 5.75 tons per ha in 2014. Compared to other ASEAN countries, Vietnam and Indonesia have the largest yield of paddy with 5.75 and 5.13 tons per ha respectively while the countries Thailand and Cambodia have relatively the low yields with 3.01 and 3.01 tons per ha respectively. In most countries except Brunei and Timor-Leste, the yield of paddy yield has increased steadily in the fifteen-years period (FAOSTAT, 2015). More detailed information about the paddy yield (hg ${ }^{7}$ per ha) in South-Eastern Asia is presented in Figure 3.1.

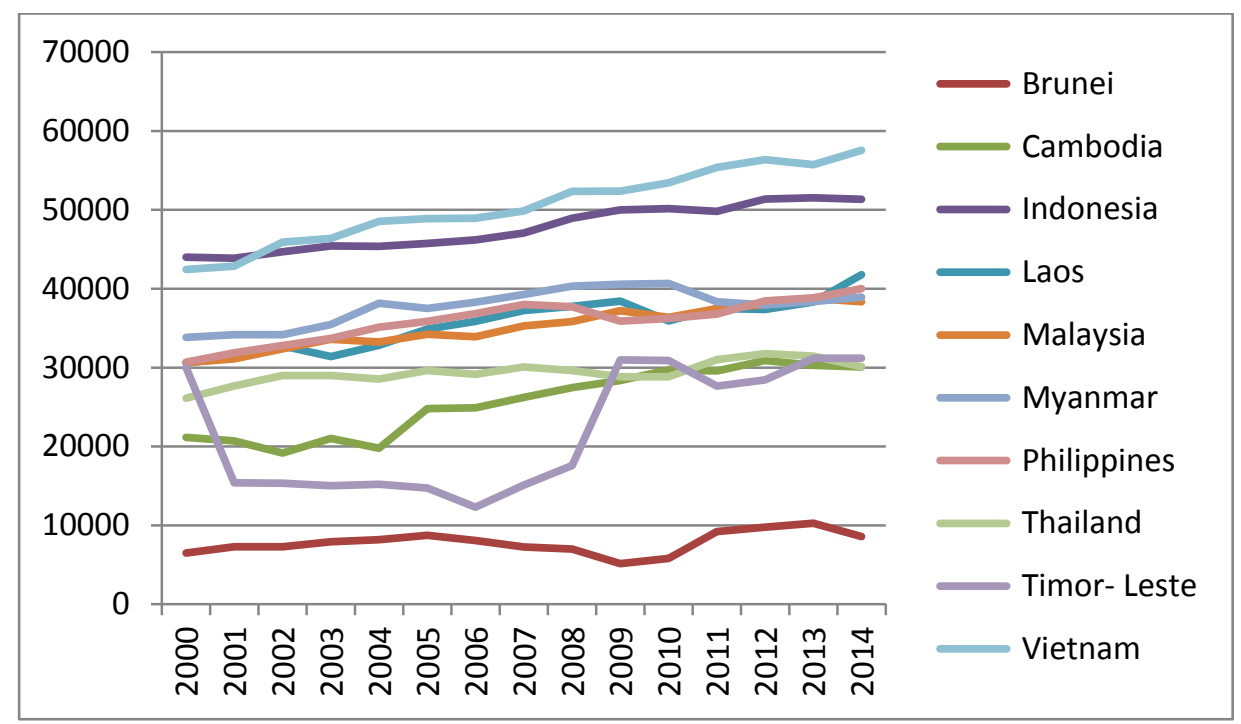

Figure 3.1. Paddy yield (hg per ha) in South-Eastern Asia

Source: (FAOSTAT, 2015)

${ }^{7} 10,000 \mathrm{Hg}=1 \mathrm{ton} ;$ 
After the renovation "Doi moi" in 1986, Vietnam has steadily increased its rice production and export volume. The RRD and the Mekong River Delta (MRD) region had the highest rice yields with 5.76 and 5.94 ton per ha respectively in comparison to other regions (Table 1) making them are the two most important regions in Vietnamese rice production (Kompas, 2002). While most of the rice produced in the MRD is exported and most of the rice produced in the RRD sold on the domestic (Vuong, 2012).

Table 3.1. Yield of paddy by different regions in Vietnam (ton per ha)

\begin{tabular}{lccccr}
\hline \multicolumn{1}{c}{ Region } & 2010 & 2011 & 2012 & 2013 & Prel. 2014 \\
\hline Whole country & 5.34 & 5.54 & 5.64 & 5.57 & 5.76 \\
1. Red River Delta & 5.92 & 6.09 & 6.04 & 5.89 & 6.02 \\
Quang Ninh province & 4.67 & 4.84 & 4.97 & 4.89 & 4.89 \\
Hai Duong province & 5.94 & 6.17 & 6.19 & 5.88 & 5.93 \\
2. Northern midlands and mountain areas & 4.63 & 4.77 & 4.82 & 4.74 & 4.84 \\
3. North Central and Central coastal areas & 5.07 & 5.32 & 5.44 & 5.36 & 5.67 \\
4. Central Highlands & 4.78 & 4.76 & 4.96 & 4.95 & 5.21 \\
5. South East & 4.48 & 4.64 & 4.75 & 4.80 & 4.91 \\
6. Mekong River Delta & 5.47 & 5.68 & 5.81 & 5.76 & 5.94 \\
\hline
\end{tabular}

Source: (GSO, 2014)

Since the rice sector plays an important role in the Vietnamese agricultural economy, many studies focus on the topics of productivity and efficiency. Vuong (2012) find that areas under rice and expenditure on pesticides have effects on rice productivity in the MRD. In addition, variables such as access to credit, educational level, district dummy, and farm technology positively influence on TE of rice producers in the region. On average, TE was about 85\%. Hoang and Yabe (2012) examine the impact of environmental factors on profit efficiency of rice farmers in the RRD by using both OLS and MLE translog profit functions. The authors found that plant disease, soil fertility, irrigation, and water pollution lead to reduce rice profits. In overall, the profitability of rice production was about $75 \%$ on average. In other studies, Huynh and Yabe (2011) calculated that the TE in Vietnam was about 81.6\% countrywide by using the VHLSS8 2006. Vu (2012) used data from the VHLSS 2004 to

\footnotetext{
${ }^{8}$ VHLSS: Vietnamese Household Living Standard Survey
} 
Chapter 3 - Collective Action Effects on Technical Efficiency of Specialty Rice Producers

measure TE that it ranged between $70.4 \%$ and $78.5 \%$. Recently, a survey conducted by Vo and Nguyen (2016) find the average of TE of rice producers in MRD was around 90\%.

Overall, the TE score was in the range of $70 \%$ and $90 \%$ so that at least rice farmers can improve efficiency up to $30 \%$ compared to other farmers without changing all of their inputs which might be a potential solution for long-term developments in Vietnamese rice sector, especially when the country is now facing the reduction of rice area due to expanding industrialization and urbanization (Nguyen et al., 2010)

\subsection{Data and Methodology}

\subsubsection{Study design and data collection}

The data collection was conducted in the Hai Duong and Quang Ninh provinces in the RRD region. These two provinces are famous for SR production of “Hoa Vang” sticky rice. A total of 280 rice farmers were randomly chosen from 18 villages and surveyed using a structured questionnaire. The full list of SR farmers was based on information from the local authorities and two SR farmer associations (Appendices 1 and 2). All data were achieved between October and December 2014 (referring to the 2013/2014 cropping season). For productivity and efficiency analysis, detailed information about land, labor, seeds, fertilizers, pesticides, other costs and outputs were questioned. The SR output was measured in amount of paddy harvested in kilogram in each individual plot. With regard to the selection criteria, the farmers surveyed have at least one plot cultivated with such a rice variety. In case of more than one plot cultivated, the largest plot of the farm was chosen for analysis purposes. Based on this data the efficiency has been calculated for each plot representatively for the particular household following the equations below.

\subsubsection{Methodology}

Stochastic frontier analysis has been applied to measure TE as it is also the common method applied in many studies in the context of developing countries (Battese and Broca, 1997; Coelli and Battese, 1996; Sharif and Dar, 1996; Wadud and White, 2000). TE is defined as how a farm obtains maximum output from a given set of inputs and technology 
(Farrell, 1957). Further, Ordinary Least Square (OLS) regression then has been used to analyze determinants of TE. Hoang (2013) provided an analytical two-stage framework to examine productive efficiency in crop production systems that includes determinants such as climatic condition, social-economic environment, farm-specific factors in addition to sociodemographic and economic characteristics. In the paper, we adopt this conceptual framework for our study as shown in Figure 3.2.

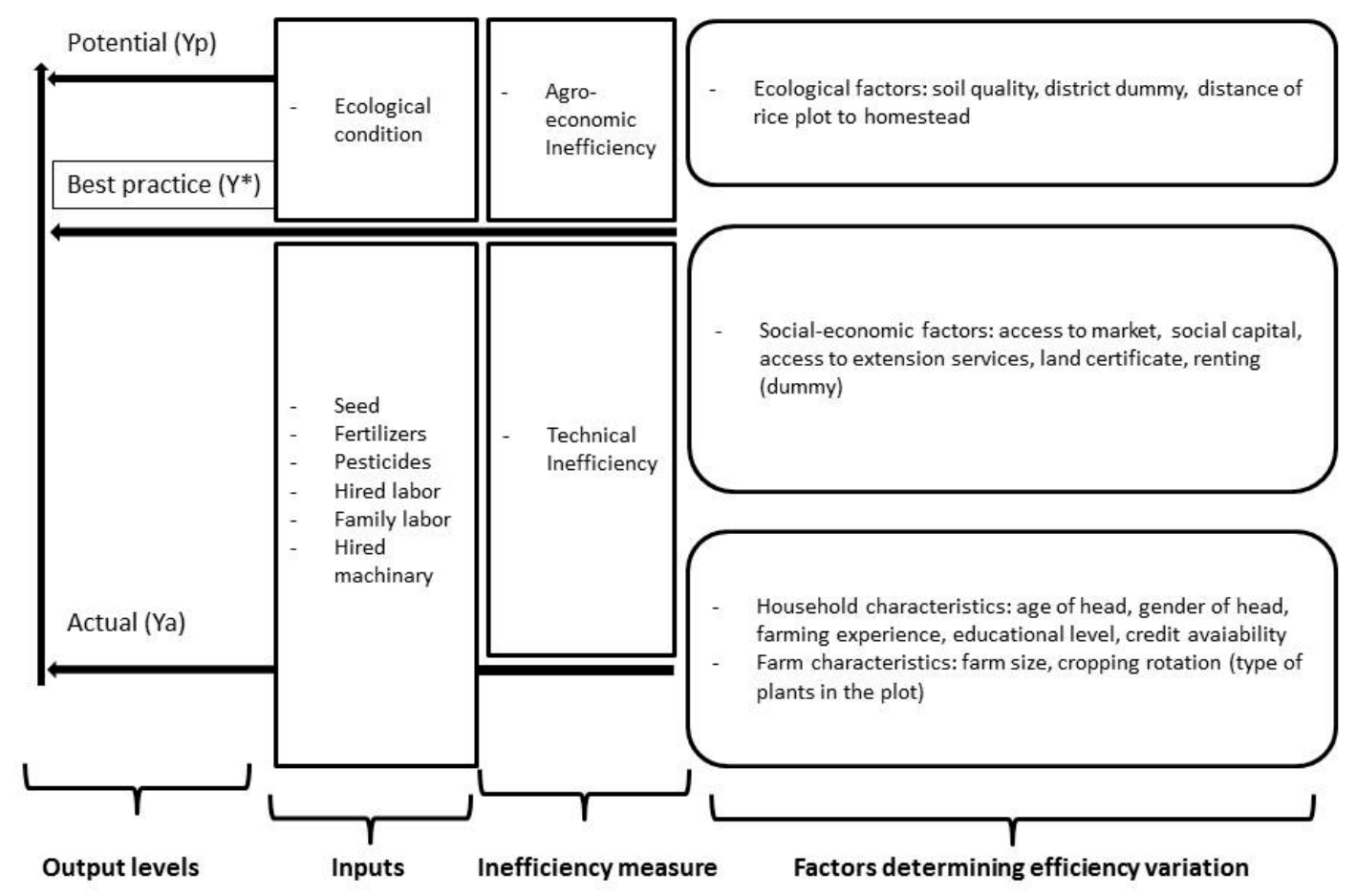

Figure 3.2: Analytical framework

Source: Adapted from Hoang (2013)

In this regard, $\mathrm{TE}$ is measured by $\mathrm{Y}_{\mathrm{a}}$ divided by $\mathrm{Y}^{*}$ or $\mathrm{TE}=\frac{\mathrm{Ya}}{\mathrm{Y} *}$, where $\mathrm{Y}$ is the actually observed output and $\mathrm{Y}^{*}$ is the best practice output level (Hoang, 2013). The general production function is defined as:

$$
y=f\left(x_{1}, x_{2}, \ldots, x_{n}\right)
$$


Where $\mathrm{y}$ is the dependent variable which can be either production function, cost function, or profit function; and $\left(x_{i}\right)$ denotes a vector of explanatory variables.

The stochastic translog production function is commonly applied as follows:

$$
y_{i}=x_{i} \beta+v_{i}-u_{i}
$$

The TE of the i-th farm, denoted by $T E_{i}$ is given by $T E_{i}=\exp \left(-u_{i}\right)$ calculated from the equation below:

$$
T E_{i}=\frac{q_{i}}{\exp \left(X_{i}^{\prime} \beta+v_{i}\right)}=\frac{\exp \left(X_{i}^{\prime}+v_{i}-u_{i}\right)}{\exp \left(X_{i}^{\prime} \beta+v_{i}\right)}
$$

During the estimation procedure, first, a translog model is applied to estimate the relationship between y and $x_{i}$ in equation 3.4.

$$
y=\exp \left(\beta_{0}+\sum_{n=1}^{N} \beta_{n} \ln x_{n}+\frac{1}{2} \sum_{n=1}^{N} \sum_{m=1}^{N} \beta_{n m} \ln x_{n} \ln x_{m}\right)
$$

In order to estimate the parameter $\beta$ in the translog model, the logarithms of both sides of the equation 2.3 are calculated leading to the equation 3.5.

$$
\ln y=\beta_{0}+\sum_{n=1}^{N} \beta_{n} \ln x_{n}+\frac{1}{2} \sum_{n=1}^{N} \sum_{m=1}^{N} \beta_{n m} \ln x_{n} \ln x_{m}+v_{i}-u_{i}
$$

The two error terms $u_{i}$ and $v_{i}$ are measures of TE of SR production and measurement errors (unobserved inputs on production) respectively. For ease of interpretation of the input-output relationships in the translog model, Coelli et al. (2005) suggested a normalization of all input and output variables by their respective sample means before running the estimation. The estimated coefficients of the first-order terms of the translog model are the input elasticities. The drawback of this model is that it requires estimation of many parameters. The estimated variance $(\gamma)$ ranges between 0 and 1 and shows the variation in production (Coelli and Battese, 1996). It is shown in equation 3.6.

$$
\gamma=\frac{\delta_{u}^{2}}{\delta^{2}}
$$




$$
\text { With: } \delta^{2}=\delta_{v}^{2}+\delta_{u}^{2} \text {. }
$$

\section{Empirical model}

Stochastic translog production function was used instead of Cobb-Douglas to estimate the production function for SR association and non-association producers owing to its flexibility and less restrictiveness on production and substitution elasticities. This choice was be confirmed by a likelihood-ratio (LR) test among the two functional forms.

Using descriptive statistics, we compared TE between SR farmers' association members and non-members since association membership is our main variable of interest. A dummy for SR farmer association membership is used in the inefficiency model estimation to analyze its effects on TE between the two groups of farmers as suggested by Coelli and Battese (1996). SR farmer associations can help farmers reduce transaction costs and, improve access to inputs. Many farmers did not use inputs from certain categories leading to missing values for many variables and observations in the dataset. To overcome this problem, Coelli and Battese (1996) suggested to use a dummy variable $\left(D_{i}\right)$ for the production costs. In this regard, costs are a summation of all input costs such as crop chemicals, organic manure, labor, and machinery.

$$
\text { Costs }=\text { maximum }\left(\text { costs, } 1-D_{i}\right)
$$

Where $D_{i}$ is equal to zero if costs of given input was zero, and $D_{i}$ is equal to 1 if cost of other inputs were positive. However, we have decided for an alternative solution to avoid the missing values categorizing and aggregating inputs (such as expenditure on family and hired labor; chemical fertilizer and pesticides; seeds, land preparation, and other costs).

Table 3.2 presents the variables used for the productivity and efficiency analysis. The first group of variables and group 2 representing technology variables are hypothesized to affect rice productivity while group 3 variables effecting TE. Production ecological theories

suggest crop yield is a function of the expenditure on seeds, chemicals, and other input costs (group 1). While technology variables such as land fertility, using manure, land fragmentation are expected to effect on SR productivity. Following Coelli and Battese 
(1996), several tests for efficiency effects using the generalized likelihood-ratio statistics were applied. Variables representing household characteristics engaged in the efficiency analysis included age of household head, gender of head, educational level, and number of adults working in agriculture. Other factors such as access to credit and extension service, membership in SR farmer association are also expected to explain TE.

Table 3.2. Description of selected variables

\begin{tabular}{ll}
\hline Variables & Description \\
\hline $\begin{array}{l}\text { Group 1: Production model } \\
\text { Yield }\end{array}$ & Yield of SR per sao in kilogram \\
Seed & Expenditure on seed in sao in kilograms \\
Chemicals & Expenditure on crop chemicals (1,000VND per sao)
\end{tabular}

\footnotetext{
${ }^{9}$ Exchange rate: US\$1 $=21,009$ VND
} 


\subsection{Results and Discussion}

\subsubsection{Descriptive Statistics}

The mean estimates of the variables later used in the stochastic translog production estimation are shown in Table 3.3. The average SR yield over the sample is $125.68 \mathrm{~kg}$, with a minimum of $65.70 \mathrm{~kg}$ and a maximum of $180 \mathrm{~kg}$. The range between the minimum and maximum yield (yield gap) could indicate a possibility of improvement of rice yield in the RRD.

The average of seed quantity is used in one unit is 27.7 (1,000VND). Total expenditure on fertilizers is approximately 217 (1,000VND) much higher than the expenditure on pesticide only 6.7 (1,000VND). Production costs are rather high due to the high-level input use required in the RRD region compared to other regions in Vietnam.

Table 3.3. Mean estimates of variables used in the stochastic translog model

\begin{tabular}{lrrrr}
\hline & Mean & \multicolumn{1}{c}{ SD } & Min & \multicolumn{1}{c}{ Max } \\
\hline Average of SR yield & 125.680 & 21.807 & 65.700 & 180.000 \\
Expenditure on seeds ${ }^{10}$ & 27.752 & 9.131 & 9.000 & 55.500 \\
Expenditure on fertilizers & 217.040 & 65.642 & 80.000 & 385.500 \\
Expenditure on pesticides & 130.588 & 44.176 & 30.000 & 270.000 \\
Expenditure on herbicide & 6.699 & 5.133 & 0.000 & 30.000 \\
Expenditure on other costs & 32.742 & 19.890 & 4.000 & 125.000 \\
Expenditure on labor & 806.102 & 146.156 & 420.000 & $1,170.000$ \\
\hline$N$ & 280 & & & \\
\hline
\end{tabular}

Note: The data was calculated on the basic of local unit “sao” or $360 \mathrm{~m}^{2}$.

Source: Authors' calculations

Differences in mean values between non-members and members of SR farmer associations for the main variables of interest are presented in Table 3.4. In the 2013/2014 cropping season, SR farmers who are members use significantly less seeds, fertilizer (NPK), and labor quantity than their counterparts. The average of members' experience in rice

\footnotetext{
${ }^{10}$ This is measured by multiplying quantity of seed and the seed's price
} 
production is about 31 years, two years less than non-members. Labor used is lower in member group which SR production activities are organized collectively.

Table 3.4. Estimates of variables used in the stochastic translog by SR farmer association membership

\begin{tabular}{lrrr}
\hline & $\begin{array}{r}\text { Non-members } \\
(\mathrm{N}=110)\end{array}$ & Members & Differences \\
& & $(\mathrm{N}=170)$ & \\
\hline Average of SR yield & 123.198 & 127.285 & -4.087 \\
Seed quantity & 1.527 & 1.382 & $0.145^{* *}$ \\
Expenditure on manure & 6.191 & 11.321 & $-5.130^{*}$ \\
Expenditure on nitrogen & 49.925 & 46.186 & 3.740 \\
Expenditure on phosphorus & 29.675 & 34.754 & -5.079 \\
Expenditure on kali & 47.892 & 49.988 & -2.096 \\
Expenditure on NPK & 71.290 & 58.199 & $13.091^{* *}$ \\
Expenditure on other fertilizers & 25.085 & 17.639 & 7.447 \\
Expenditure on pesticide and herbicide & 139.276 & 132.415 & 6.861 \\
Total labor quantity & 4.809 & 4.415 & $0.394^{* * *}$ \\
Other costs & 21.345 & 20.048 & 1.298 \\
Expenditure on other costs & 32.859 & 32.666 & 0.192 \\
Number of productive laborers & 2.973 & 3.153 & -0.180 \\
Head of household has a high school degree & 0.264 & 0.341 & -0.078 \\
Household head worked off-farm & 0.473 & 0.471 & 0.002 \\
Experience in growing rice & 33.555 & 31.365 & $2.190^{*}$ \\
Land quality & 0.818 & 0.829 & -0.011 \\
\hline$N$ & 280 & & \\
\hline
\end{tabular}

Note: ${ }^{*} p<0.10,{ }^{* *} p<0.05,{ }^{* * *} p<0.01$;

Source: Authors' calculations

There no significant differences between the two groups for many of the variables such as expenditure on chemical fertilizers, expenditure on herbicide, and other costs. This might due to the fact that the production of SR varieties mainly bases on extensive experience of producers who are familiar with all the production techniques. It is important to note that SR varieties are considered low yielding varieties so that there might be no significant difference between non-members (123.2 kg per sao) and members (127.3 kg per sao). However, the SR yield is much lower than other varieties in the RRD region. 


\subsubsection{Parameter Estimates}

a) Determinants of rice productivity and efficiency

The coefficients of the production frontier are shown in table 3.5 for the full sample (280 SR farmers), members (170 households) and the non-members of SR farmer association (110 households). As the data is log-normalized, the coefficients on the input level term represent their production elasticities at the mean. The partial production elasticities relating to labor and expenditure on crop chemicals are 0.09 and 0.04 at the 5\% significance level. However, the other input costs (such as water supply and storage) have negative effects on the production function in the model of the full sample. Both estimates of $\sigma_{u}$ and $\sigma_{v}$ are significantly different from zero at the 5\% level. 
Table 3.5. Parameter estimates for the stochastic translog model for SR

\begin{tabular}{|c|c|c|c|}
\hline VARIABLES & Full model $(\mathrm{N}=280)$ & Member $(\mathrm{N}=170)$ & Non-members $(\mathrm{N}=110)$ \\
\hline \multirow[t]{2}{*}{ Ln seed } & -0.03384 & -0.06227 & 0.00050 \\
\hline & (0.04969) & $(0.06324)$ & $(0.08023)$ \\
\hline \multirow[t]{2}{*}{ Ln chemicals ${ }^{11}$} & 0.03063 & $0.05769 *$ & -0.03566 \\
\hline & $(0.02883)$ & $(0.03348)$ & $(0.06533)$ \\
\hline \multirow[t]{2}{*}{ Ln other cost } & $-0.04125^{* *}$ & $-0.04470^{*}$ & -0.02556 \\
\hline & $(0.02001)$ & $(0.02682)$ & $(0.04497)$ \\
\hline \multirow[t]{2}{*}{ Ln labor } & $0.09369 * *$ & 0.08679 & 0.02981 \\
\hline & $(0.04387)$ & $(0.05559)$ & $(0.07859)$ \\
\hline Ln seed x Ln seed & $(0.02349)$ & $(0.02879)$ & $(0.04431)$ \\
\hline \multirow[t]{2}{*}{ Ln seed $x$ Ln chemicals } & $-0.08973^{*}$ & -0.05892 & -0.19411 \\
\hline & $(0.04818)$ & $(0.06477)$ & $(0.31258)$ \\
\hline \multirow[t]{2}{*}{ Ln seed $x$ Ln other cost } & -0.04820 & 0.03195 & -0.08900 \\
\hline & $(0.03682)$ & $(0.04463)$ & (0.18199) \\
\hline \multirow[t]{2}{*}{ Ln seed x Ln labor } & 0.13528 & $0.29784^{* *}$ & 0.23876 \\
\hline & $(0.09695)$ & $(0.12361)$ & $(0.28355)$ \\
\hline Ln chemicals $x$ Ln chemicals & 0.07034 & 0.16276 & 0.15346 \\
\hline \multirow{2}{*}{ Ln chemicals x Ln other cost } & $0.12654 * *$ & $0.18757 * *$ & 0.00031 \\
\hline & $(0.06225)$ & $(0.08060)$ & $(0.10835)$ \\
\hline \multirow[t]{2}{*}{ Ln chemicals x Ln labor } & 0.05086 & 0.05068 & 0.05324 \\
\hline & $(0.14791)$ & $(0.18073)$ & $(0.26682)$ \\
\hline \multirow[t]{2}{*}{ Ln other cost x Ln other cost } & $-0.02064 * *$ & $-0.03752 * * *$ & -0.00069 \\
\hline & $(0.00920)$ & $(0.01440)$ & $(0.01684)$ \\
\hline \multirow[t]{2}{*}{ Ln other cost $x$ Ln labor } & 0.03942 & 0.02238 & 0.19780 \\
\hline & $(0.06000)$ & $(0.12144)$ & $(0.14536)$ \\
\hline \multirow[t]{2}{*}{ Ln labor x Ln labor } & -0.09871 & -0.04688 & -0.35077 \\
\hline & $(0.18267)$ & $(0.23000)$ & $(0.29732)$ \\
\hline \multirow[t]{2}{*}{ Constant } & $0.06209 * * *$ & $0.06734 * * *$ & -0.02205 \\
\hline & $(0.01814)$ & $(0.01963)$ & $(0.02583)$ \\
\hline
\end{tabular}

Note: ${ }^{*} p<0.10,{ }^{* *} p<0.05,{ }^{* * *} p<0.01$; Source: Authors' calculations

${ }^{11}$ Chemicals include expenditure on fertilizers and pesticides excluding manure. 
Table 3.6 presents the results for the determinants of inefficiency jointly estimated with the stochastic translog production function for the whole sample of SR farmers. Negative coefficients indicate that the variables have a significant positive effect on the TE. Variables such as SR planted area, female gender of the household head, household head worked off-farm, experience in growing rice, and membership in SR farmer association have positive effects on TE of which, SR association membership is the most influential determinant of TE. This result suggests that becoming a member of SR farmer association is a way of improving economic performance. However, the magnitude of effect of SR association membership is small: $9.4 \%(\mathrm{p}<0.01)$.

The coefficient of farmers' age has a negative sign (at 5\% significance level) implying that the older rice producers are less technically efficiency than younger producers. This is conform with results obtained by Wadud and White (2000), Huynh and Yabe (2011), Vu (2012). However, Coelli and Battese (1996) find that the age of the farmers could have a positive and negative effect on the efficiency.

Interestingly, female-headed households are more technically efficiency than male-headed households. A possible explanation is that female rice farmers might have better skills than males since they more involve in many farming practice. The results is in contrast to the results of Hoang and Yabe (2012) and Ulimwengu and Badiane (2010), while other studies from Vuong (2012) and Huynh and Yabe (2011) did not find any effect of gender on TE.

The negative and significant coefficient of the household head worked off-farm variables indicates that farmers engaged in off-farm activities tend to increase in efficiency level. It can be explained by increasing investment or expansion of planted area under SR (from an additional earning) that has a positive effect on efficiency. This is in contrast to the result of Abdulai and Eberlin (2001) with maize and bean crops in Nicaragua.

Experience in SR production and planted area under SR appear to have a positive effect on TE (at 1\% significance level). These findings are consistent with the work of Tan et al. (2010), Coelli and Battese (1996), and Kompas (2002). 
Table 3.6. Parameter estimates for the inefficiency model for SR (full sample)

\begin{tabular}{lr}
\hline Variables & Coef \\
\hline Inefficiency model & $0.00185^{*}$ \\
Age of the household head (years) & $(0.00109)$ \\
Female-headed (1=yes) & $-0.04250^{* *}$ \\
& $(0.02165)$ \\
Number of productive laborers in the household & -0.00775 \\
& $(0.00695)$ \\
High school degree (1= yes) & -0.02634 \\
The household head worked off-farm (1=yes) & $(0.01640)$ \\
& $-0.04600^{* * *}$ \\
Experience in growing SR rice (years) & $(0.01414)$ \\
SR planted area $\left(m^{2}\right)$ & $-0.00257 * * *$ \\
& $(0.00091)$ \\
Technology & $-0.02263^{* * *}$ \\
Fertile land (1=yes) & $(0.00683)$ \\
\hline Using manure before planting (1=yes) & -0.02355 \\
Distance to homestead (kilometer) & $(0.02386)$ \\
Membership of SR farmer association $(1=y e s)$ & -0.01456 \\
Constant & $(0.01920)$ \\
\hline Observations & -0.00001 \\
\hline
\end{tabular}

Note: Robust standard errors in parentheses; ${ }^{*} p<0.10,{ }^{* *} p<0.05,{ }^{* * *} p<0.01$

Source: Authors' calculations

b) Effect of collective action on rice productivity and technical efficiency

Summary statistics of the TE scores as the level of production performance for SR farmers are presented in Table 3.7. A technical efficiency measure of 100 implies that efficiency completely explained by selected explanatory variables in the stochastic translog model. Overall, the mean of TE for the whole sample is $77.1 \%$ and ranges between $50.4 \%$ and 97.8\%. Members in SR farmer associations have slightly higher TE scores than their 
counterparts, $79.4 \%$ compared to $73.5 \%$ respectively. The frequency distribution of predicted TE of SR farmers is also given in appendix 3.

Table 3.7. TE scores for SR producers

\begin{tabular}{|l|c|c|c|c|c|c|}
\hline \multicolumn{1}{|c|}{ TE score } & N & Mean & Var & SD & Min & Max \\
\hline Full sample & 280 & 0.771310 & 0.008975 & 0.094735 & 0.50385 & 0.977944 \\
\hline Members & 170 & 0.794422 & 0.008152 & 0.090286 & 0.53373 & 0.977944 \\
\hline Non-members & 110 & 0.735590 & 0.008212 & 0.090622 & 0.50385 & 0.945596 \\
\hline
\end{tabular}

Source: Authors' calculations

\subsection{Concluding Remarks and Policy Implications}

It was the objective of this study to quantify the role of collective action TE in developing and transition countries using an example of SR producers of Vietnam. The results of the analysis show an average TE of SR farmer in the RRD region is 77\% implying that TE in SR production in the RRD can still be increased by $30 \%$ at the current inputs level and technology. These results are similar with previous studies in rice production in Vietnam (Hoang and Yabe, 2012; Huynh and Yabe, 2011; Vu, 2012). In this regard, results also suggest that becoming a member of SR farmer association is a way of improving economic performance for many of the farmers since there is a small variation in production efficiency among the households in the sample. The magnitude of effects of SR association membership is with about $10 \%(\mathrm{p}<0.01)$ relatively low. That might be due to the fact that many members do not fully comply with the technical protocol of their SR association. Additionally, higher labor costs have significant positive effect on SR yield whereas other input costs have negative effect. Since rice production in the RRD bases on labor intensive, meanwhile other inputs were over-used.

Other factors such as planted area under SR, women headed households, off-farm employment of the household heads, greater experience in rice farming also significantly contribute to SR production efficiency $(\mathrm{p}<0.05)$, whereas advanced age of household head tends to reduce production efficiency $(\mathrm{p}<0.1)$. Interestingly, technology related factors that we expected to have significant effects turned out to be insignificant. They included land fertility, use of organic manure, and distance from SR plot to homestead. One explanation 
could be there is not significant difference between environment factors in the RRD region where two provinces (Hai Duong and Quang Ninh) have similar geographic characteristics. Overall the results give evidence that there is potential to enhance the functioning of SR farmer associations to improve SR farmers’ efficiency in Vietnam. Thereby, it is necessary to support them in their important role in training farmers on best production practices, reducing transaction costs in production and marketing of SR, up scaling adoption of SR varieties and stabilizing TE in rice production. These farmer associations could also play a significant role in collective bargaining for better SR prices on behalf of their members. These findings supports earlier studies on other countries and products by Bavorova et al. (2005), Gedara et al. (2012), and Wollni and Brümmer (2012) showing that farmer associations or cooperatives play an important role in improving agricultural productivity and TE. As a result, policy improvements supporting farmer associations based extension services and improving access to productive inputs such as quality seeds, fertilizers, and pesticides would be beneficial for the small farmers. In this regard it is of special importance to strengthen the internal control system in SR farmer associations in order to encourage SR producers in fulfilling the technical protocol. The implications of these results are not limited to the RRD region alone but applicable across regions and such initiatives could enhance SR production and marketing among small farmers in Vietnam.

Gender issues in SR production, the extent of farmers' participation in the farmer associations, and duration of participation in the farmer associations may also influence productivity and TE in a positive or negative way but we could not analyze all these important issues due to data limitations. These are important issues worth following up in future studies. 


\title{
4. Determinant of Smallholder Farmers' Choice of Marketing Channels: Evidence from the Rice Sector in Vietnam ${ }^{12}$
}

\begin{abstract}
Cash crops such as specialty rice and other high-value varieties produced for domestic and international markets are considered an increasing source of income for smallholder farmers in many Asian countries. This study focuses on the factors affecting Vietnamese specialty rice farmers' choice of marketing channels and how their choice influences farm performance. The analysis has been conducted using multinomial logit and linear regression models on quantitative data collected from 280 specialty rice farmers in the Red River Delta, one of the main rice production regions in Vietnam. Results reveal that even though local collectors and wholesalers are still the most common actors farmers deliver to in rural areas, reduction in transaction costs with regard to uncertainty influences famers to choose modern marketing channels through collective action (via specialty rice farmer association). This collective marketing channel helps farmers increase average prices received by US\$0.028 per $\mathrm{kg}$ of paddy. Based on the results, manifold political implications are derived.
\end{abstract}

\footnotetext{
12 This paper was written in collaboration with Dr. Verena Otter and Prof. Dr. Ludwig Theuvsen at the Department of Agricultural Economics and Rural Development, University of Goettingen.
}

Submitted: 23.11.2016. Under Review at the Asian Economic Journal. 


\subsection{Introduction}

In recent decades, non-traditional marketing chains, such as supermarkets or export markets, have come to coexist with traditional marketing chains through wholesale market or collectors/wholesalers in developing and transition countries. This has created more profitable opportunities for farmers to sell their products. Thus, small-scale farmers can choose from among an increasing number of different types of potential buyers. As a result, researchers and policy-makers have turned their attention to new agri-food systems and farmers' choice of marketing channels (Fafchamps and Hill, 2005; Goetz, 1992; Rao et al., 2012). There is a large body of literature about the relationship between collective action and market access. In this regard, social network variables, such as membership in local associations and networks or participation in collective action, can improve the market participation of small-scale farmers (Fischer and Qaim, 2012; Markelova et al., 2009; Moustier et al., 2010; Narrod et al., 2009). Among researchers, access to modern marketing channels is considered an important tool for lifting farmers out of poverty and enhancing food security in developing countries (Barrett, 2008; Fischer and Qaim, 2012). Additionally, literature on collective action has indicated that by organizing, farmers have more bargaining power and fewer transaction costs (Ouma et al., 2010). Nevertheless, smallholder farmers can still face various barriers (e.g., farm size, marketing information) to entrance into non-traditional markets, especially those for high-value and specialty products that have not yet been thoroughly empirically investigated (Blandon et al., 2009).

One of these specialty products is rice of certain varieties. Vietnam produces approximately 44 million tons of rice annually, whereof $15.23 \%$ are sold to the export market and $84.77 \%$ to the domestic market (FAOSTAT, 2015). Many Vietnamese small-scale farmers depend on rice as their main source of income (Nielsen, 2003). Currently, rice farmers are increasing their income by growing high-value and specialty varieties. The term specialty rice (SR) in the context of this study refers to glutinous varieties, sometimes also called sticky rice or golden flower glutinous rice, which is grown mainly in Southeast and East Asia, for example, in Laos, Thailand, and Vietnam. These varieties are famous for their

origin in specific regions and sold mainly to the domestic market, where they command a 
premium price. In essence, glutinous rice is a traditional variety that has been upgraded in seed quality due to development programs in recent years (Jaenicke et al., 2010). From a marketing perspective, it has a price premium due to its superior quality. According to data from Vietnam's National Office of Intellectual Property, four rice varieties have names that reflect their geographical place of production and by 2015, 21 other rice varieties were protected under a collective mark.

However, there is a lack of transparency regarding marketing information in the traditional market for SR varieties (Moustier et al., 2010). Thus, earlier qualitative research on the Vietnamese rice sector has suggested that smallholders' participation in specialized marketing channels through membership in cooperatives and associations selling to supermarkets or private companies can help overcome information asymmetries in the SR market sector and increase household incomes. Conversely, participation without such a membership is still associated with the typical barriers to entry including limited access to credit, third-party certification, and information about quality controls, and, therefore with high transaction costs. Nevertheless, whether or not Vietnamese smallholder rice producers can glean potential financial benefits or not for from participating in domestic modern marketing channels through collective action has never been quantified (Moustier et al., 2010). Considering the importance of the sector from a development economics perspective, this represents a huge research gap.

This study seeks to close this gap by analyzing marketing channels in the Vietnamese rice sector. It has two main objectives: (1) to explore the determinants influencing SR farmers' choice of marketing channels with regard to marketing information, access to credit, and social networks by analyzing the rice supply chain structure, marketing opportunities, and farmers' preferences and (2) to determine the influence of collective marketing and direct marketing channels (sales to end consumers) on rice farmers' performance (quantity produced, quantity sold, and farm gate price). This study uses data from 280 smallholder SR farmers in Vietnam and applies a multi-specification model. The results are of particular interest to producers of and traders in the raw products in developing and transition 
countries as well as policy-makers in Vietnam and beyond in order to optimally support smallholder farmers.

The rest of the article is organized as follows: Section 4.2 gives an overview of the rice marketing channel system in Vietnam. Section 4.3 describes the data, methodology, and conceptual framework. Then section 4.4 presents the results of the quantitative analysis. Finally, the article closes with conclusions and implications for policy-makers in developing countries regarding the development of non-traditional marketing channels for high-quality and regional products in rural areas.

\subsection{Background}

\subsubsection{Complex Vietnamese Marketing Channels of Rice and their characteristics}

Overall, rice marketing channels in Vietnam have developed remarkably since the economic renovation ${ }^{13}$ introduced in the late 1980s. There was a significant increase in the number of rice farmers participating in national rice markets (Cazzuffi and McKay, 2012; Minot and Goletti, 2000). The proportion of households selling rice countrywide increased from $42.8 \%$ in the $1992 / 1993$ cropping season to $54 \%$ in 2008 . The literature indicates that there is a small difference between rich and poor rice farmers in terms of marketed surplus. Furthermore, Vietnamese rice production is characterized by multiple cropping, small farms, labor-intensive production practices, and overuse of fertilizers (Minot and Goletti, 2000).

During the 1990s the rice marketing channels in Vietnam were a complex system that differed among from one region of the country to the next (Minot and Goletti, 2000). At that time, the traditional rice marketing channel in Vietnam was dominated by the private sector, including rice farmers (most of them small-scale), rice millers, rice collectors, wholesale traders, retailers, and end consumers. Since then, new buyers such as agricultural cooperatives, farmer associations, food companies, and supermarkets have entered the domestic as well as the export rice markets, especially in the Red River Delta (RRD) and

\footnotetext{
13 "Renovation" is the term used for the economic reforms initiated in Vietnam in 1986.
} 
the Mekong River Delta (MRD). Of these, collectors and wholesalers are the farmers' preferred trading partners and therefore the most common in villages. In each commune there is at least one collector with full equipment such as a four-wheel-tractor, motorbikes, and a resident milling machine, who can offer a variety of services to small-scale farmers: supplying inputs, milling, buying paddy or providing informal credit.

According to Minot and Goletti (2000) nearly $60 \%{ }^{14}$ of rice farmers in the rural areas of the RRD sold rice and faced the complex marketing system (Figure 4.1), compared to only $42.8 \%$ on the national level in the 1992-1993 harvest season. In the first marketing channel of the system, farmers sell their products directly to end consumers after milling their paddy. For transport, bus services or motorbikes are often used to deliver SR to buyers or consumers in the cities. For success in this direct marketing channel (DMC) farmers usually need to rely on their urban networks (e.g., relatives, friends) since high-quality and SR varieties are sold through the DMC to urban end consumers at higher prices based on its origin being guaranteed by word of mouth. However, small-scale farmers might still face challenges when selling larger quantities of rice. As a result, many farmers in rural areas tend to deliver their SR paddy to the second marketing channel in the system: the traditional marketing channels (TMC) with local collectors or wholesalers acting as direct trading partners. Products are then resold to urban wholesalers, food companies, shop retailers, and finally to the end consumers. In this channel, most of the farmers choose to sell their paddy at the farm gate and know at least one collector or wholesaler in their village. When marketed surplus ${ }^{15}$ is sold through TMC, however, a large amount of rice has no trade mark or label; the main disadvantage for farmers is that they must rely on their buyers for marketing information (e.g., prices) and have limited bargaining power. Due to these challenges, a third marketing opportunity has emerged: the SR farmer associations (MFA) (Frédéric and Dao, 2005; Moustier et al., 2010). This channel was first created in

\footnotetext{
${ }^{14}$ The data was calculated on the basic of the Vietnam Living Standards Survey 1992-1993 obtained from Vietnam's General Statistics Office.

${ }^{15}$ Marketed surplus is the quantity actually marketed.
} 
the early 2000s in the RRD region with the support of the government institutions, international organizations, and NGOs. By establishing SR farmer associations, the MFA has applied the strategy of buying SR directly from rice farmers and organizing several processing steps such as milling, packaging, and branding products with their collective mark. Then, products are delivered to end consumers either through supermarkets, restaurants, or shop retailers. Moustier et al. (2010) highlighted that farmer organizations play a crucial role in directly supplying supermarkets with rice in Vietnam. In fact, farmer associations not only buy SR from their members but also from non-members if their products meet the basic requirement of the organizations.

The rice market in the RRD is dominated by wholesale markets in big cities (e.g. Hanoi, Hai Phong, and Quang Ninh). Currently, SR farmers produce more for commercialized purposes and prefer the MFA over the TMC due to premium prices. In the case of Tam Xoan flavored rice ${ }^{16}$ produced in the Nam Dinh province, for example, rice farmers received a US\$0.01 per kg higher price by selling through the farmer association than through traditional marketing channels (Moustier et al., 2010). In the Hai Duong province, products are mainly delivered to supermarkets, urban wholesalers, and shop retailers in the big cities through farmer associations in the region. They label the SR with the collective trade mark and sell it at a premium price. Members are selected based on location, SR production, willingness to join and acceptance of the association's regulations (Dao and Sautier, 2011). It should be noted that Nam Dinh and Hai Duong province are the most famous areas for producing SR in the RRD region.

\footnotetext{
${ }^{16}$ This is the traditional rice variety grown mainly in the Hai Hau district, Nam Dinh province. Its quality is high, its flavor is good, and it is sold at a premium price.
} 


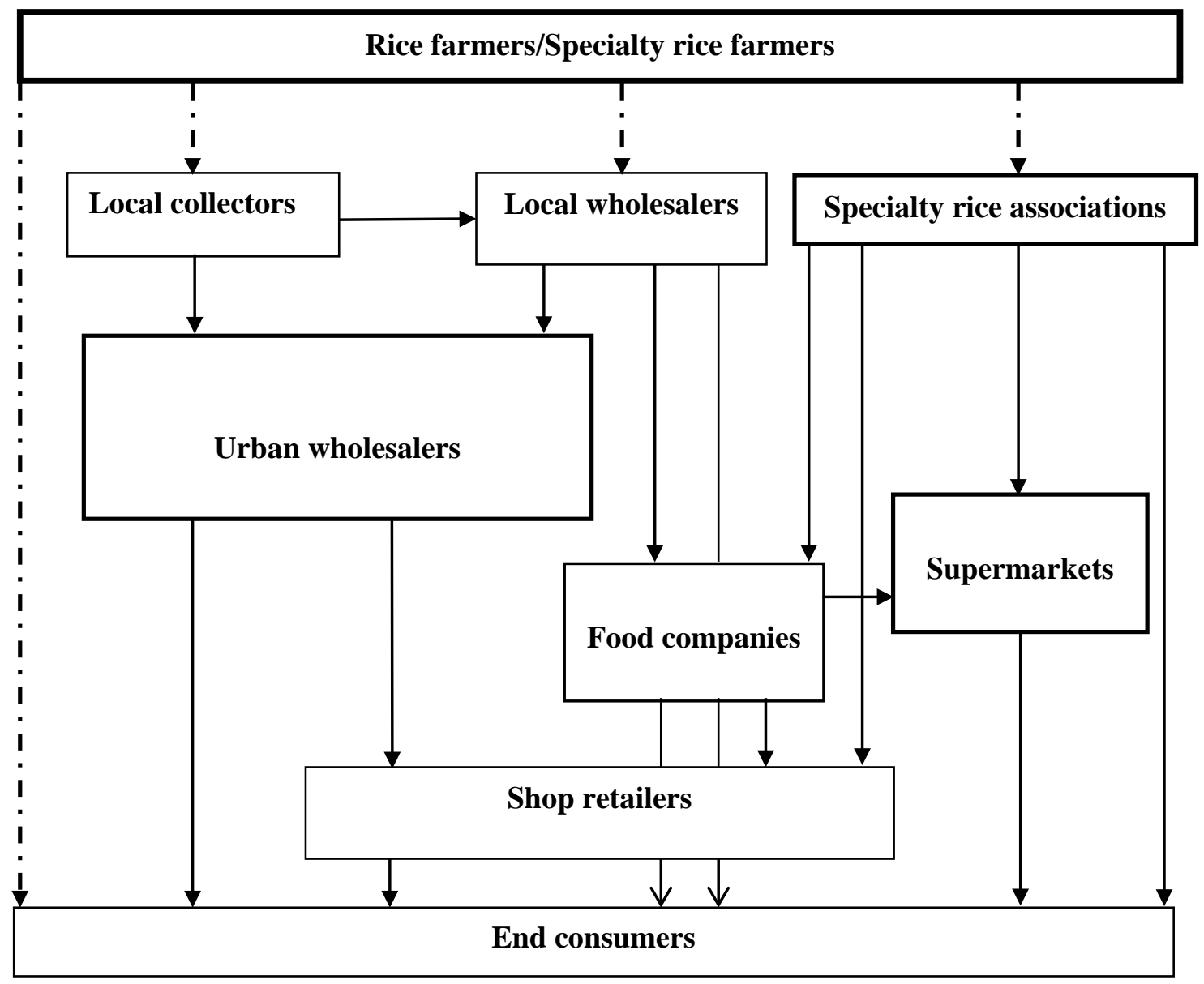

Figure 4.1. Rice marketing channel system in the Red River Delta

Source: Authors' illustration adapted from (Frédéric and Dao, 2005; Jaenicke et al., 2010; Minot and Goletti, 2000; Moustier et al., 2010).

\subsubsection{Linking smallholder farmers to international SR rice markets}

Vietnam produces several SR varieties (see Appendix 6) that are protected as GIs, collective marks, and certificated marks. Even though those products are mainly concentrated on the domestic market, they present a high potential for the international market. While Thailand and India have succeeded in address niche marketing approaches for such certifications to access European or the US markets, Giraud (2013) found that the US and Vietnam are now interested in accessing these markets. Specifically, GI institutionalization is gaining more attention since it shows the relationship between a 
specialty product, specific quality attribute, and its origin (Biénabe and Marie-Vivien, 2015; Chaudhary, 2003; Jena and Grote, 2012; Josling, 2006).

In order to export high-value and SR varieties to niche markets, producers must ensure the quality of products with certain criteria and certification. In addition, other actors in rice value chain such as millers or exporting companies have to meet the requirements of international buyers. These issues have been mentioned in the early study on rice production in Bangladesh by Ghani et al. (1993). The authors found that exporting these varieties could bring the economic potential meanwhile there have been some constraints such as: low level of consumers' awareness of SR varieties, high standardized requirements from buying countries, and high level of competition.

In case of fragrant rice, one of SR varieties, that has been widely commercialized in international niche markets with a premium price. Its demands has increased gradually from rich importing countries (Chaudhary, 2003; Giraud, 2013). Therefore, the competitiveness between exporting countries will be high with some new enters like Vietnam, the US, and Cambodia.

In many Asian countries, the majority of farmers are small-scale. In order to adopt GI or other certifications to access niche markets they need to be themselves organized. Ngokkuen and Grote (2012) found membership of cooperatives increasing the likelihood of GI certification adoption in case of Jasmine rice from Thailand. At the farm level, factors such as high transaction costs or lack of certified buyers could lead to decrease the intensity of GI adoption.

In overall, there are opportunities for rice farmers who produce high-value or certified varieties to access international markets. It is important to enhance rice value chains (e.g., , upgrading traditional varieties, improving farming, drying and milling technologies, ) and to ensure the quality of rice (e.g., food safety, nutritional value) in order to target these markets (Chaudhary, 2003; FAO, 2014). 


\subsubsection{Smallholder Farmers and Collective Action}

There is a growing body of literature on farmer associations, cooperatives, and farmers' development. These organizations are considered new institutions in many rural areas of developing and transition countries (Barham and Chitemi, 2009; Bernard and Spielman, 2009; Deininger, 1995; Wollni and Zeller, 2007). In addition, a great deal of evidence indicates that collective action is a valuable tool for small-scale farmers who want to access markets successfully (Barham and Chitemi, 2009; Markelova et al., 2009; Moustier et al., 2010; Reardon et al., 2003; Thorp et al., 2005), improve bargaining with buyers (Thorp et al., 2005) and increase their performance (Barham and Chitemi, 2009) based on economies of scale (Hoff et al., 1993; Narrod et al., 2009). Wollni and Brümmer (2012) found that farmers' membership in coffee cooperatives influences farm-specific efficiency in the case of specialty coffee production in Costa Rica. This is supported by a study from Bavorova et al. (2005), who determined that agricultural association membership in the Czech agricultural sector has a significant positive impact on farm performance through the services offered by the associations such as trainings and consultancy services. In the case of rice production in Sri Lanka, Gedara et al. (2012) proved that membership and active participation in farmer organizations have a significant influence on TE among rice producers. In the Vietnamese context, Dao and Pham (2013) and Jaenicke et al. (2010) stressed that farmer organizations play a role in improving production techniques and rice yield in Vietnam.

However, there is a lack of transparency regarding marketing information in the TMC for SR varieties. Earlier qualitative research on the Vietnamese rice sector has suggested that smallholders' participation in specialized marketing channels through membership in cooperatives or associations, and selling to supermarkets or private companies might help overcome information asymmetries in the SR market and increase household incomes (Moustier et al., 2010). This is supported by the fact that small-scale farmers producing SR face challenges with selling larger quantities of rice, especially in the DMC, at higher prices and therefore with covering the costs of investments for such purposes as certification and specialized inputs (Jaenicke et al., 2010). On the other hand, participation in SR markets in 
Vietnam without membership in a farmer association is still associated with the typical barriers to entry (for example, limited access to credit, third-party certification, and information about quality controls).

Since the most important barriers to entry in modern marketing channels are associated with determinants causing higher transaction costs (Moustier et al., 2010), the conceptual design of this study is based on the transaction cost theory (TCT) introduced by Williamson (1985). This predictive approach aims to explain differences in the organization of transactions and identifies three principal dimensions uncertainty, asset specificity and frequency as the main determinants for these differences. High levels of uncertainty arise from unpredictable environmental changes and/or a lack of communication for strategic as well as non-strategic reasons and may lead to higher degrees of vertical coordination between farmers and their buyers such as membership in and supply of farmer associations. In the Vietnamese SR sector especially a lack of communicated marketing information can be observed leading to increasing search and negotiation costs during transactions (Escobal and Cavero, 2012; Moustier et al., 2010). Furthermore, Williamson (1985) argues generally that uniqueness of production inputs is relatively frequent. This is particularly true of differentiated products, such as SR, which require even more transaction-specific investments (asset specificity). In addition to production inputs, the marketing of SR in Vietnam requires the certification of products on the farm-level which obliges farmers to run internal control systems and to use certified seeds and manure or organic fertilizers. Since transaction-specific investments are closely related to lock-in effects supply chain actors often substitute autonomous trading on the spot market though trading relations with a higher degree of vertical coordination before investing specifically. This trend toward specialized governance is also linked to a lower degree of transaction frequency (Williamson, 1985). However, since frequency has not been identified as a critical dimension in the Vietnamese SR sector in previous qualitative research (Moustier et al., 2010), it will not be included in our analysis.

Our research model (Figure 4.2) includes measures for the two main dimensions of transaction costs considered to be most relevant for Vietnamese SR production: uncertainty 
and asset specificity (Moustier et al., 2010; Williamson, 1985). Additionally, we hypothesize that rice households with larger social networks (e.g., through the number of farmer organizations ${ }^{17}$ they belong to except for SR farmer associations in the MFA channel) and network size ${ }^{18}$, it is more likely they will choose MFA than other marketing channels since producer groups help their members to exchange information. This is based on Wollni and Zeller (2007) who demonstrated this link for coffee producers in Costa Rica. Hence, social network parameters were also included in the model, as were farm characteristics (e.g., farm size and location) (Zivenge and Karavina, 2012) and the farmers' sociodemographic characteristics such as education level (Escobal and Cavero, 2012) and age (Fischer and Qaim, 2012) which have also been identified as determinants of farmers' marketing channel choice in previous studies of other cases and countries.

Farm size is of particular interest in the context of Vietnamese SR production since larger farmers tend to sell most of their products at the farm-gate to local collectors and wholesalers in the TMC for simplicity reasons (Cazzuffi and McKay, 2012). In contrast, smaller farmers producing a smaller amount of rice prefer to sell their products to farmer associations (MFA) and directly to end consumers (DMC).

\footnotetext{
${ }^{17}$ Organizations that at least one member of household is involved in such as an agricultural cooperative, farmers' union, women’s union, youth union, elder association, and/or veteran association.

${ }^{18}$ Network size is measured by how many close farmers a household can rely on if it faces financial problems or other hardship. A close farmer is defined as a farmer in the village the respondent regularly talks to and shares information with about SR production.
} 


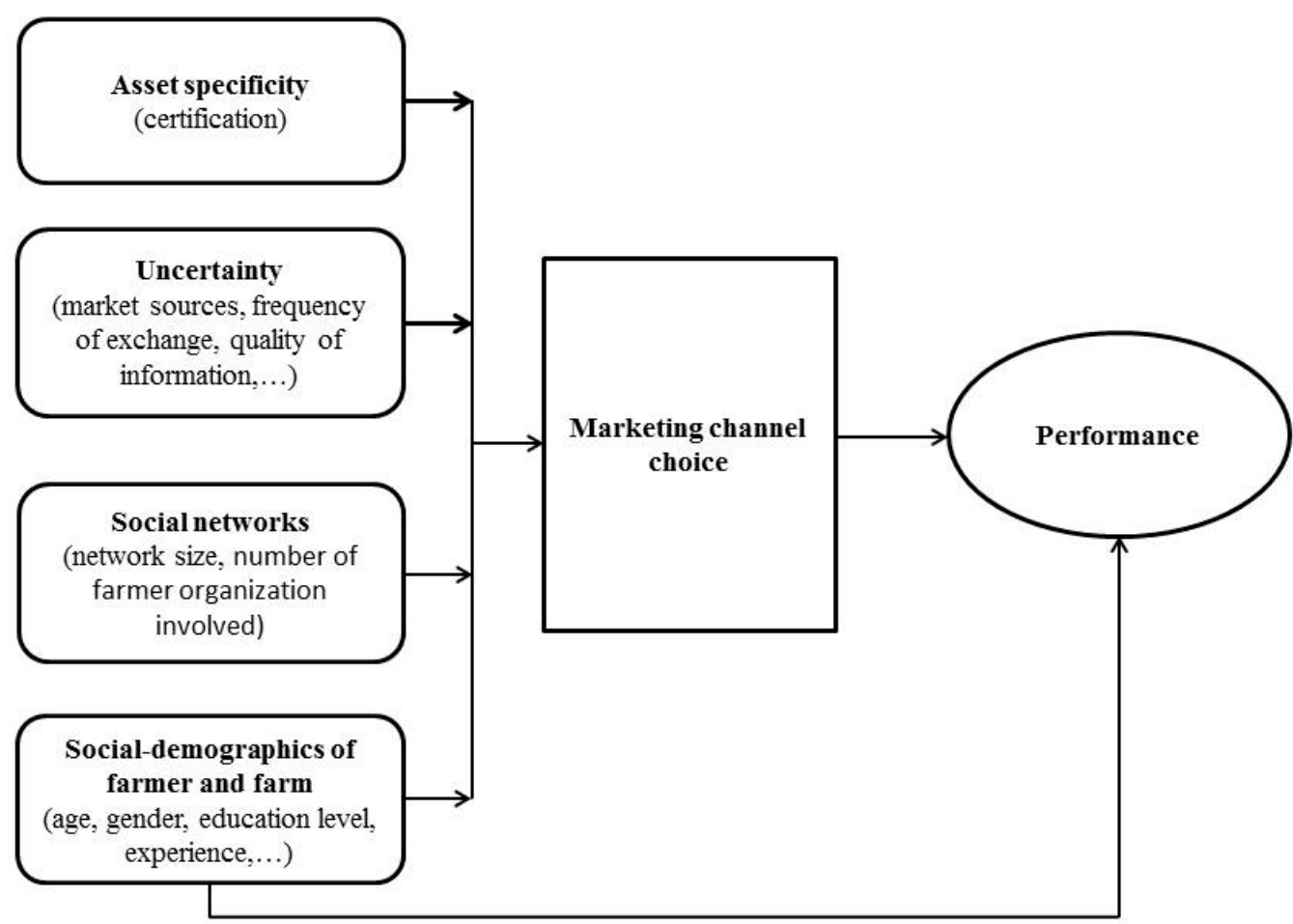

Specialty rice farmers' participation in markting channels

Figure 4.2. Conceptual framework of farmers' choices of marketing channels

Source: Authors’ illustration

\subsection{Data and methodology}

\subsubsection{Study design and data collection}

Data collection was conducted in two provinces in the RRD region, the $2^{\text {nd }}$ largest rice producing and marketing region in Vietnam (see Figure 3). A total of 280 rice farmers were randomly chosen from 18 villages and surveyed using a structured questionnaire. All data concerned the 2013/2014 cropping season and were collected between October and December 2014. During the interviews, farmers were asked about their source of marketing information, the importance of each source, how much marketed surplus they delivered to each marketing channel, and the price of that surplus. For analysis purposes, we only used data from 258 households (90\% of sample) who participated in the SR market. These 
farmers were grouped by marketing channel choice using the following strategy: If only one marketing channel was delivered by a farm it was assigned to the particular group. If the farmers supplied rice to more than one channel, we computed the share of marketed surplus that went to each channel, and the channel that got the largest allocation (more than $50 \%$ of marketed quantity) was deemed the main one. Thus, each of the farmers in our sample supplied over $50 \%$ of his rice to a particular channel.

\subsubsection{Methodology}

To analyze the causality behind smallholders' choice of SR marketing channels in Vietnam, we chose a multinomial logit regression model. This model is suitable for analyzing unordered responses with more than two choices (Wooldridge, 2010). Thus, farmers' choice of marketing channels can be analyzed as shown below:

$$
y_{i}=\beta_{0}+X_{i j}^{\prime} \beta_{j}+\varepsilon_{i j}
$$

In this model, $y_{i}$ represents the vector of the dependent variable describing the farmers' marketing channel choice, and $X_{i j}^{\prime}$ the vector of independent variables measuring uncertainty, asset specificity, farm characteristics, network parameters, and farmers' sociodemographics.

SR marketing channels are chosen without obvious ordering. Thus, a single alternative ( $\mathrm{j}$ ) is selected from a number of marketing channels based on the utility level $\left(U_{i j}\right)$ (Greene, 2012; Verbeek, 2004; Wooldridge, 2010).

$$
U_{i j}=X_{i j}^{\prime} \beta_{j}+\varepsilon_{i j}(4.2)
$$

$\varepsilon_{i j}$ is the unobservable error term assumed to be normally distributed with $\mathrm{i}=1, \ldots, \mathrm{N}$ individual households and $\mathrm{j}=0,1, \ldots, \mathrm{j}=0, \ldots ., \mathrm{J}$ alternatives. The alternative chosen has the highest level of utility. The multinomial model is estimated using the maximum likelihood method:

$$
\log L=\sum_{i} \sum_{j} d_{i j} \log p_{i j}
$$

The probability that alternative $\mathrm{j}$ will be chosen is

$$
P\left(y_{i}=j\right)=P\left(U_{i j} \geq U_{i k} \mid x, \forall k \neq j\right)=P\left(\varepsilon_{i k}-\varepsilon_{i j} \leq X_{i j}^{\prime} \beta_{j}-X_{i j}^{\prime} \beta_{k} \mid x, \forall k \neq j\right)(4.4
$$


The marginal effects are:

$$
\frac{\partial P_{i j}}{\partial X_{i k}}=P_{i j}-\sum_{m=1}^{J-1} P_{i m} \beta_{m k} ; \mathrm{j}=1, \ldots, \mathrm{j}-1
$$

Each $\beta_{j}$ represents the influence of selected independent variables on the chosen alternatives $j$ to $m$. Besides farmers' sociodemographic characteristics, the variables of interests in order to explain farmers' choices of SR marketing channels were uncertainty, asset specificity, farm characteristics, and network parameters.

Within a random utility framework the utility of each alternative is a linear function of observed characteristics plus an additive error term (Verbeek, 2004). Each farmer will choose to market the SR through marketing channels if the utility gained from participation in a selected marketing channel is greater than that of other marketing channels with selected independent variables (Figure 4.2). In order to measure marketing performance, we use simple OLS regression to explore which factors influence such performance:

$$
\text { Producer price }_{\mathrm{i}}=\mathrm{X}_{\mathrm{i}}^{\prime} \beta_{i}+\beta_{0} * \text { Marketing channel }+\varepsilon_{\mathrm{i}} \text { (4.6) }
$$

where $X_{i}^{\prime}$ is a vector of control variables such as social characteristics. The dummy variables for two marketing channels are MFA and DMC.

\subsection{Results and Discussion}

\subsubsection{Descriptive Statistics}

Within the total sample, over 90\% of SR farmers (258 out of 280) participated in rice markets with an average marketed surplus of $404 \mathrm{~kg}$ per farm. Approximately 55\% of the respondents (142 farmers) sell to the TMC, 28\% (73 farmers) to the MFA, and nearly 17\% (43 farmers) to the DMC. Thus, the TMC is the most common marketing channel for SR in the RRD region.

Table 4.1 the mean values and T-tests of mean differences of the variables used in the regression analyses. Even though for many of the variables, there are no significant differences between the groups, significant differences in the mean values exist for the size of land cultivated and the value of livestock owned, indicating that farmers participating in 
the TMC are larger than those participating in the other two channels. Additionally, farmers participating in the TMC have significantly better access to extension services, hire more workers and have a higher volume of marketed outputs than farmers selling to the DMC.

Also, for the distance to the nearest local market and the producer prices attained significant differences in mean values were found. Farmers participating in the TMC face longer distances to the next central market and receive lower prices than farmers participating in a MFA or DMC. Farmers participating in a MFA are better educated (38\% have a high school degree) than those participating in the TMC (only 26\% have a high school degree). Farmers involved in MFA own more production related assets, such as carts, harvesting machines and storage facilities. However, for other variables related to sociodemographic characteristics (e.g. age, female-headed, household size, and experience) no significant difference between groups was found. 
Chapter 4 - Determinant of Smallholder Farmers’ Choice of Marketing Channels

Table 4.1. Household characteristics by choice of marketing channel

\begin{tabular}{|c|c|c|c|c|c|}
\hline & $\begin{array}{c}\text { MFA } \\
\text { (1) }\end{array}$ & TMC & DMC & $\begin{array}{c}\text { Mean } \\
\text { difference }\end{array}$ & $\begin{array}{c}\begin{array}{c}\text { Mean } \\
\text { difference }\end{array} \\
\text { (2)-(3) }\end{array}$ \\
\hline Age of the household head & 53.21 & 52.87 & 53.16 & -0.33 & -0.29 \\
\hline Female-headed & 0.29 & 0.37 & 0.35 & 0.08 & 0.02 \\
\hline High school degree & 0.38 & 0.26 & 0.37 & $-0.12^{*}$ & -0.11 \\
\hline Household size & 3.64 & 3.83 & 3.74 & 0.19 & 0.09 \\
\hline Experience in growing rice & 29.79 & 29.73 & 29.02 & -0.07 & 0.70 \\
\hline Use hired labor & 0.30 & 0.38 & 0.16 & 0.08 & $0.22^{* * *}$ \\
\hline Works off-farm & 0.47 & 0.47 & 0.49 & 0.01 & -0.02 \\
\hline Access to credit & 0.42 & 0.44 & 0.44 & 0.02 & 0.00 \\
\hline Access to extension & 0.78 & 0.76 & 0.60 & -0.02 & $0.16^{* *}$ \\
\hline Marketing information & 0.33 & 0.43 & 0.47 & 0.10 & -0.04 \\
\hline $\begin{array}{l}\text { Distance to SR association } \\
\text { headquarters }(\mathrm{km})\end{array}$ & 0.97 & 1.33 & 0.93 & $0.36^{* * *}$ & $0.40^{* * *}$ \\
\hline Total cultivated land $\left(\mathrm{m}^{2}\right)$ & $2,851.79$ & $3,598.02$ & $2,615.78$ & 746.23 & $982.25^{*}$ \\
\hline SR cultivated area $\left(\mathrm{m}^{2}\right)$ & $1,602.64$ & $1,539.48$ & $1,013.27$ & -63.16 & 526.21 \\
\hline Number of rice varieties & 2.82 & 2.71 & 2.95 & -0.11 & $-0.24^{* *}$ \\
\hline Total paddy (kg) & $2,648.38$ & $3,090.69$ & $2,356.67$ & 442.31 & $734.02^{*}$ \\
\hline SR paddy (kg) & 585.93 & 560.32 & 372.30 & -25.61 & $188.02^{*}$ \\
\hline SR marketed surplus (kg) & 496.51 & 459.51 & 275.05 & -36.99 & $184.47^{* *}$ \\
\hline Price per kg (1,000 VND $\left.{ }^{19}\right)$ & 18.46 & 17.16 & 18.14 & $-1.30^{* * *}$ & $-0.98^{* *}$ \\
\hline Value of livestock (1,000 VND) & $4,793.51$ & $13,724.48$ & $6,428.14$ & $8,930.97^{* * *}$ & $7,296.34^{* *}$ \\
\hline Owns cart ${ }^{20}$ & 0.71 & 0.51 & 0.58 & $-0.21^{* * *}$ & -0.07 \\
\hline Owns harvesting machine & 0.23 & 0.12 & 0.21 & $-0.11^{* *}$ & -0.09 \\
\hline Owns storage facility & 0.64 & 0.51 & 0.60 & $-0.14^{*}$ & -0.10 \\
\hline Observation & 73 & 142 & 43 & & \\
\hline
\end{tabular}

Note: ${ }^{*} p<0.10,{ }^{* *} p<0.05,{ }^{* * *} p<0.01$

Source: Authors' calculations

Note: Dummies for: household head's gender (1=female); household head's educational level (1=with high school degree); using hired labor (1=yes); household worked off-farm (1=yes); access to credit (1=yes); access to extension service (1=yes); marketing information received (1=farmer has more than one marketing source); experience with any shock (1=yes); Dummies for owning a cart, harvesting machine, and storage facility (1=yes). Marketing channel was sorted by the mainly (over $50 \%$ of marketed surplus).

After identifying their source, rice farmers were asked to rate the importance of each on 5point Likert scales. Descriptive results revealed that even though farmers stated that they do

\footnotetext{
${ }^{19}$ Exchange rate: US $\$ 1=21,400$ VND (at the time of survey conducted, December 2014)

${ }^{20} \mathrm{~A}$ cart is a two wheeled vehicle designed for transport. In the RRD region, carts are commonly re-designed be pulled by motorbikes and used to transport inputs and outputs.
} 
not receive marketing information from farmer associations and extension agents as frequently as from other sources, they rate the importance of information from these sources more highly (e.g., mean of 4.25 for extension agents and 4.36 for farmer associations if these sources are used most frequently) than information from TMC or neighbors. These results support the important role of farmer organizations and extension agents in rural areas in providing marketing information.

Table 4.2. Access to marketing information and the importance of marketing sources

\begin{tabular}{|c|c|c|c|c|c|c|}
\hline \multirow[b]{2}{*}{ Sources } & \multicolumn{2}{|c|}{ Most frequent source } & \multicolumn{2}{|c|}{$2^{\text {nd }}$ most frequent source } & \multicolumn{2}{|c|}{$3^{\text {rd }}$ most frequent source } \\
\hline & Frequency & $\begin{array}{c}\text { Importance } \\
\text { score }\end{array}$ & Frequency & $\begin{array}{c}\text { Importance } \\
\text { score }\end{array}$ & Frequency & $\begin{array}{c}\text { Importance } \\
\text { score }\end{array}$ \\
\hline Neighbor & 127 & 3.78 & 38 & 3.89 & 5 & 2.8 \\
\hline Trader & 112 & 3.81 & 97 & 3.77 & 3 & 3.33 \\
\hline $\begin{array}{l}\text { Extension } \\
\text { agent }\end{array}$ & 4 & 4.25 & 4 & 3.5 & 1 & 4 \\
\hline TV or radio & 2 & 4 & 0 & - & 3 & 4 \\
\hline Internet & 0 & - & 1 & 4 & 0 & - \\
\hline Researcher & 3 & 4.67 & 3 & 4.33 & 2 & 4 \\
\hline $\begin{array}{l}\text { SR famer } \\
\text { association }\end{array}$ & 28 & 4.36 & 18 & 4.33 & 7 & 4.86 \\
\hline Total & 276 & & 161 & & 21 & \\
\hline
\end{tabular}

Note: (1- Very unimportant; 2- Slightly unimportant; 3- Neither important nor important; 4- Slightly important; 5- Very important); Source: Authors' calculations

With regard to the performance of SR farmers in the RRD region Table 4.3 shows mean values and T-tests for quantities of SR produced and prices received for it by nonmembers and members of SR farmer associations separately. Even though on average about $80 \%$ of the total output produced by both groups is sold to the domestic Vietnamese SR market, members produce, self-consume, and market significantly higher quantities than nonmembers. Additionally, members received a significantly higher price for their marketed surplus (US\$0.039 per kg more on average, or 830 VND) than their counterparts. In fact, many members choose not to sell to their SR farmers associations. 
Table 4.3. Distribution of SR output, by membership

\begin{tabular}{lrrr}
\hline & $\begin{array}{c}\text { Non-members } \\
(N=110)\end{array}$ & \multicolumn{1}{c}{ Members } \\
& & $(N=170)$ & \\
\hline Quantity produced (kg) & 360.05 & 598.36 & $-238.31^{* * *}$ \\
- Seed for next season (kg) & 4.37 & 6.83 & $-2.46^{* *}$ \\
- Home consumption (kg) & 55.21 & 66.29 & $-11.08^{*}$ \\
- Gift (kg) & 26.40 & 36.27 & $-9.87^{*}$ \\
- Marketed surplus (kg) & 274.07 & 489.26 & $-215.19^{* * *}$ \\
Price (1,000VND) & 17.16 & 17.99 & $-0.83^{* * *}$ \\
\hline
\end{tabular}

Note: ${ }^{*} p<0.10,{ }^{* *} p<0.05,{ }^{* * *} p<0.01$;

Source: Authors' calculations.

\subsubsection{Determinants of Marketing Channel Choice}

Table 4.4 presents the empirical results of a multi-choice function analysis of farmers' marketing decisions through the three marketing channels. To run the model, we chose TMC as the base option in order to compare it with the two other marketing channels. The coefficients shown in the first and second column represent the coefficients and probability of choosing a MFA instead of TMC. The third and fourth column interprets the coefficients and the probability of substituting either DMC or TMC. The marginal effect (ME) illustrates that each unit increase in the selected independent variable increases or decreases the probability of selecting an alternative marketing channel.

Among the household demographic variables, the household head having a high school degree positively and significantly influences the decision to choose MFA. If a rice farmer has a high school degree then the probability of selecting MFA increases by $8.2 \%$. In addition, if farmers tend to sell more products, they are more likely to choose MFA and less likely to select a DMC. However, the magnitude of this effect is still limited.

With regard to marketing information, if a farmer acquires an additional marketing source the probability that farmer will select a MFA increases by approximately $10 \%$. This is a very important result since rice farmers often lack access to marketing information before making their decision to sell their SR paddy. Providing them with additional marketing sources will give them more bargaining power and reduce their uncertainty when making 
deals with local traders. As mentioned in Table 4.2, extension agents, researchers, and leaders of SR farmer associations play a crucial role in providing additional good marketing information.

Table 4.4. Determinants of SR marketing channels in RRD region (Multinomial logit)

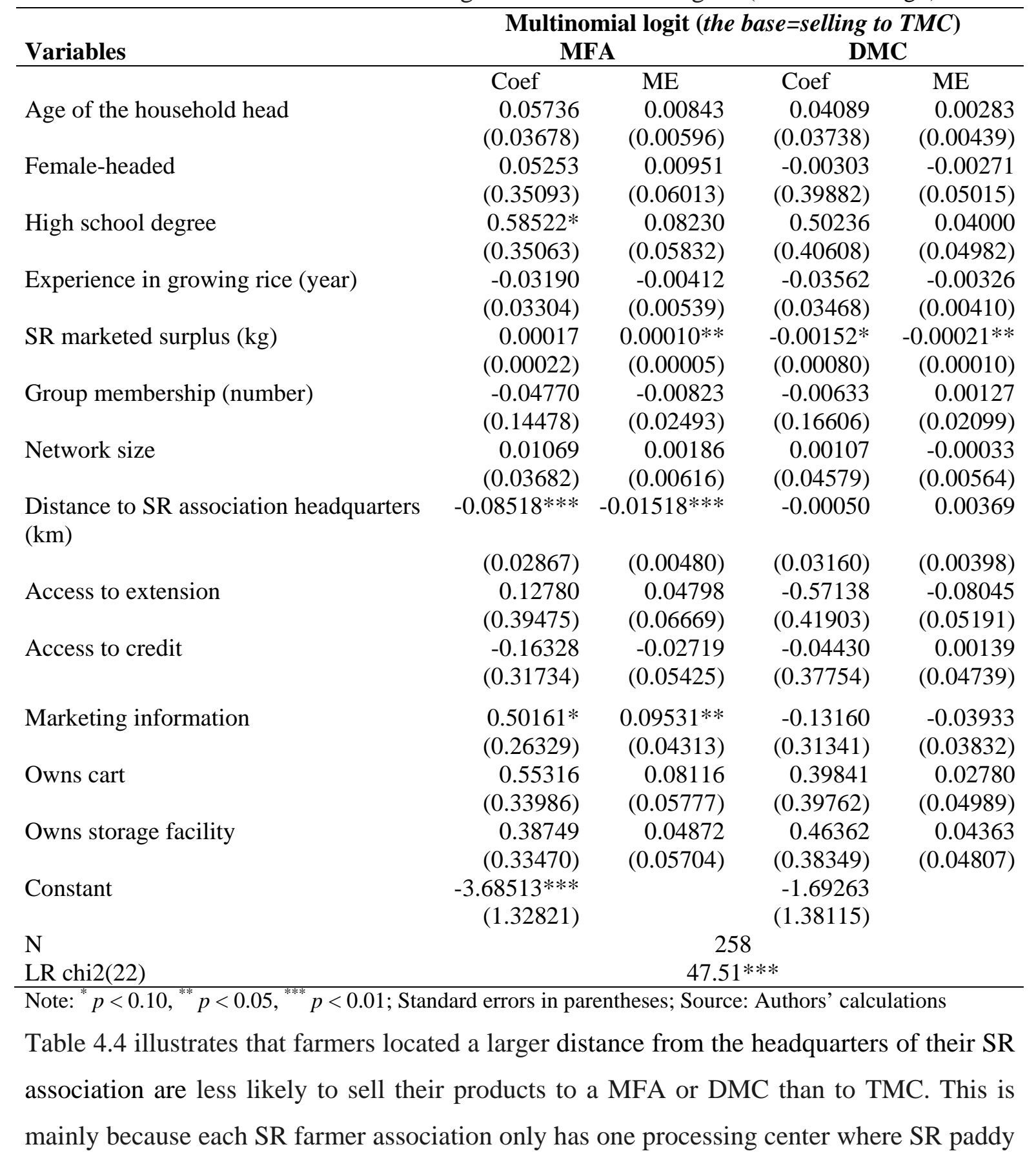


is milled and packaged with their own brand name. The distance to the farmer association might become a constraint on SR farmers selling through such organizations. In fact, farmer organizations are planning to invest more on process equipment for each commune. Another explanation is that in the RRD, there is generally one collector per commune. Farmers may have a preferred collector in their village even though they are offered lower prices compared to wholesalers or SR farmer associations. However, rice growers can buy inputs such as fertilizers and pesticides or borrow money from collectors and pay it back after harvesting their paddy. Because of this, many farmers cannot choose other marketing channels.

\subsubsection{Influence of Collective Marketing on Farmers' performance}

SR is considered a cash crop because farmers do not use it as a main staple food like other rice varieties. In this section, we focus on the marketing channel performance of SR. Instead of using the amount of SR paddy sold as the main indicator for measuring marketing performance, we used the producer price since it has a closer link to farm income. To determine the relationship between selected explanatory variables to the SR paddy price, we applied an OLS regression model with the price received as the dependent variable.

The empirical results are displayed in table 4.5. Model 1 gives the outcomes of the regression without including dummies for the nontraditional marketing channels (MFA and DMC), which are the main variables of interest in our study. Several explanatory variables are expected to have an effect on performance. Model 2 shows the regression with the full set of variables.

The factors that explain the price of SR paddy are distance to SR association headquarters, the duration of SR is kept in stock, marketed surplus, access to credit, network size, and group membership. Interestingly, we observed that access to credit has a negative significant impact on marketing chain performance. Both formal and informal credit service have a negative sign; this can be explained by the relation between rice farmers and other credit institutions such as wholesalers and fertilizer agents. First, many farmers take out loans for nonfarm investments (e.g., building houses or buying motorbikes), which can 
affect investment in SR production. Second, the credit institutions offer many services to rice farmers (e.g., selling fertilizers, pesticides, and herbicides) in advance, meaning that farmers can pay back the loan after harvesting their paddy. As the results show, the farm gate price of some farmers with a loan was lower than the price non-borrowers received.

Table 4.5. Marketing chain performance (OLS regression)

\begin{tabular}{|c|c|c|}
\hline Variables & Model 1 & Model 2 \\
\hline \multirow{2}{*}{ Age of the household head } & 0.00778 & 0.00192 \\
\hline & $(0.01609)$ & $(0.01598)$ \\
\hline \multirow[t]{2}{*}{ Female-headed } & -0.35849 & -0.31108 \\
\hline & $(0.28394)$ & $(0.27996)$ \\
\hline \multirow[t]{2}{*}{ High school degree } & 0.28450 & 0.17806 \\
\hline & $(0.29102)$ & $(0.28931)$ \\
\hline \multirow[t]{2}{*}{ Access to extension } & -0.18647 & -0.15476 \\
\hline & $(0.32878)$ & $(0.32389)$ \\
\hline \multirow[t]{2}{*}{ Access to credit } & $-0.52033^{*}$ & $-0.51551^{*}$ \\
\hline & $(0.27323)$ & $(0.26889)$ \\
\hline \multirow[t]{2}{*}{ Distances to SR association headquarters (km) } & $-0.05183 * * *$ & $-0.03892 *$ \\
\hline & $(0.01980)$ & $(0.02015)$ \\
\hline \multirow[t]{2}{*}{ Duration specialty paddies kept in stock (months) } & $0.25468 * * *$ & $0.27143^{* * *}$ \\
\hline & $(0.05095)$ & $(0.05140)$ \\
\hline \multirow[t]{2}{*}{ SR marketed surplus (kg) } & $-0.00060 * * *$ & $-0.00061 * * *$ \\
\hline & $(0.00020)$ & $(0.00020)$ \\
\hline \multirow[t]{2}{*}{ Network size } & $0.08587 * * *$ & $0.08147 * * *$ \\
\hline & $(0.03074)$ & $(0.03041)$ \\
\hline \multirow[t]{2}{*}{ Group membership } & 0.08838 & 0.08021 \\
\hline & $(0.12120)$ & $(0.11931)$ \\
\hline \multirow[t]{2}{*}{ Marketing through SR farmer association (MFA) } & & $0.59517^{*}$ \\
\hline & & $(0.31415)$ \\
\hline \multirow[t]{2}{*}{ Direct marketing channel (DMC) } & & $0.91242 * *$ \\
\hline & & $(0.36781)$ \\
\hline \multirow[t]{2}{*}{ Owns cart } & 0.01682 & -0.05387 \\
\hline & $(0.28494)$ & $(0.28193)$ \\
\hline \multirow[t]{2}{*}{ Owns storage facility } & 0.18395 & 0.06618 \\
\hline & $(0.27141)$ & $(0.27073)$ \\
\hline \multirow[t]{2}{*}{ Constant } & $17.01712^{* * *}$ & $16.96020^{* * *}$ \\
\hline & $(0.91554)$ & $(0.90148)$ \\
\hline Observations & 177 & 177 \\
\hline $\mathrm{F}(12,167)$ & $6.66 * * *$ & $6.42^{* * *}$ \\
\hline R-squared & 32.8 & 35.7 \\
\hline
\end{tabular}

Note: ${ }^{*} p<0.10,{ }^{* *} p<0.05,{ }^{* * *} p<0.01$; Standard errors in parentheses;

Source: Authors' calculations 
SR paddy can be kept in a good condition up to one year after harvesting. As can be seen, the time rice was kept in stock in the 2013/2014 cropping season had a positive and significant influence on the price of SR paddy. In addition, the network size variable positively influenced the price the farmers received. These results are consistent with the results of the qualitative studies by Moustier et al. (2010) and Dao and Sautier (2011). Meanwhile, distance to SR association headquarters significantly negatively influences SR price. The result is also consistent with the literature about transaction costs (Ouma et al., 2010). As expected, farmers participating in a MFA and DME receive a higher price of approximately 595VND (US\$0.028) and 912VND (US\$0.043) per kg of SR paddy respectively. Those variables increase the R-squared from 32.8\% to 35.7\%. However, household characteristics (e.g., age, gender, and education) have no significant influence on producer price.

\subsection{Concluding remarks and policy recommendations}

In this study, we analyzed the factors influencing marketing channel choice among small rice farmers in the RRD region of Vietnam and the influences of their marketing channel choice on farmer performance. The results reveal that, even though farmers in rural areas most commonly deliver to local collectors and wholesalers, the reduction of transaction costs with regard to uncertainty and asset specificity increasingly leads many farmers to choose modern marketing channels through collective action. Especially the number of marketing information sources has a highly significant influence on farmers' participation in a MFA. Even though, it was also found that farmer associations and extension agents are evaluated by farmers as the most important sources of marketing information, the availability of these sources is still limited at the farm level since only about $10 \%$ of farmers are reached frequently. In this regard, we recommend having more support for those organizations in order to overcome the lack of marketing information and other uncertainties in specialized markets. Furthermore, asset specificity plays a crucial role in SR farmers marketing channel choice since the distance to the headquarters of the farmer associations has a negative influence on farmers’ participation in the MFA channel. To 
overcome these distances, farmers need investments geared specifically to transportation vehicles (e.g., carts or tractors) or storage facilities, but these are closely related to credit access. Even though, several credit programs exist in rural RRD regions, they exert no influence on choice of marketing channels (which is also true of the variables representing storage and tractor ownership) and even have a negative impact on farm performance. This is usually due to the fact that loans are not used for the purposes for which they were intended; that is, they are not used for farm assets. This is a failure to which the malfunction of control bodies also contributes.

In addition to transaction cost related influences, sociodemographic characteristics of the farmer, such as education level, also have a significant influence on selling SR rice to the MFA marketing channel since better educated farmers are more successful in bargaining with trading partners. This result is consistent with the literature about the adoption of cooperative marketing and specialty marketing channels (Corsi et al., 2009; Wollni and Zeller, 2007; 2007).

In particular, it can be suggested that local authorities need to encourage SR production and marketing by improving rural infrastructure, providing better marketing information for rice farmers, enhancing the rural education system, focusing more on credit policy and enhancing the capacity of farmer associations in rural areas. This is of particular importance since the results of this study also show that collective marketing helps farmers increase the average price received per $\mathrm{kg}$ of rice by US $\$ 0.028$; thus, modern marketing channels offer better market opportunities to small-scale farmers and help increase household income. Against this background, small-scale farmers' participation in collective action is considered a suitable marketing channel choice for producing and selling specialized crops in a modern market environment, which is in line with earlier studies in a similar environment and products in developing and transition countries (Markelova et al., 2009; Moustier et al., 2010; Rao et al., 2012; Rao and Qaim, 2013).

Future research should target the long-term impact of SR marketing channels on household income by using panel data. In addition, the participation in SR farmer associations and 
MFA might lead to biased and inconsistent coefficients. In such a case, the instrument variable regression approach could be improved. It is also important to analyze the impact of farmer organizations on SR rice productivity and efficiency as well as and consumers' preference for SR varieties and collective mark. 


\section{General Conclusions}

Our study objectives were achieved as expounded in the three essays. The dissertation therefore contributes to literature in many ways by analyzing certain aspects of SR adoption which have limitedly been studied in existing literature. We analyze the role of social networks, marketing information, and collection action in SR adoption process, the drivers of farmers' marketing channels choice and farm performance. We find that the SR farmer association plays a crucial role in the development of SR value chain and improvement of rural livelihoods in Vietnam.

\subsection{Main findings}

The introductory chapter of this dissertation gives an overview of the Vietnamese rice sector, particularly its important role in achieving food security and improving household welfare. From this point of view, the following objectives have been addressed: First, we explored the farmers' decision to adopt specialty rice (SR) production. Secondly, we analyzed the effect of collective action via a SR farmer association on farmers' technical efficiency (TE). Finally, we examined the drivers of farmers' choice of marketing channels. The study employed T-tests and different regression models on cross-section data from a sample of 336 rice farmers of RRD to address these objectives. Based on the results, we have provided policy recommendations for different stakeholders as the Government, local authorities, policy-makers and those involved in the SR value chain to upgrade the rice sector in Vietnam.

In Chapter 2, we contribute to the literature on adoption decision of SR varieties relating to social networks and group membership in rural areas of developing countries. We find that these factors positively and significantly influence the probability of SR adoption. These findings have policy implications on strengthening farmers' networks and encouraging participation in producer groups to enhance SR production. Furthermore, a larger rice area under cultivation, more experience of farmers in growing rice, and higher investment in 
productive assets tend to raise the probability of SR adoption. Larger farm size and increased investment in productive assets (e.g., carts or storage facilities) also enhance intensity of SR adoption through increased acreage of SR varieties. These results suggest that actions such as land consolidation, rice land preservation policies, and expansion of agricultural land markets would be beneficial. The distances to the nearest local market seems to be the major obstacle to SR adoption. Infrastructural improvements on roads and SR farmers associations (collective action) in the rural areas therefore would increase access to high-value markets. In view of the Vietnamese governments' strategy to strengthen the rice value chain, there is the need to certify and brand SR varieties to avert quality adulteration, enhance specialized markets, and build the Vietnamese national rice brand for long-term development.

In the Chapter 3, we analyze the effects of collective action on farmers' TE. Our results show that SR farmers can increase their TEs by 30\% at the current input levels and production technology. This essay contributes to the literature on the effects of collective action with regard to production efficiency in developing countries, which is gaining more attention from researchers and policy-makers. By participating in SR farmer associations, the members can increase their TE by nearly $10 \%$ compared to non-members. It is suggested that collective action can be important in improving the smallholder farmers' welfare. Furthermore, we find that female-headed farming households are more efficient than male-headed ones since women are more involved in farming activities. An additional year of experience in growing rice increases farm performance. From the productivity analysis, we find that the current level of input use (fertilizers, pesticides, and herbicides) do not have positive effects on SR yield due to possible inappropriate application of the inputs as documented in previous studies on challenges of rice production in Vietnam.

Chapter 4 contributes to literature on marketing participation and farmers' choice of marketing channels that are very important in the context of developing countries where smallholder farmers find difficulties in accessing high-value markets. One major reason we identify in our study is imperfect marketing information. The majority of the rice farmers 
get marketing information from their neighbors or local traders. Only about $10 \%$ of SR farmers access marketing information from farmer associations and extension agents. From the regression results, one additional marketing information source increases the probability of selecting a collective marketing channel where rice farmers receive higher prices than on the local markets. However, we find that local collectors or wholesalers acting as middlemen dominate the TMCs along the rice value chain in the study areas. Many farmers prefer these intermediaries that offer lower prices due to imperfect marketing information. In addition, longer distances to the SR farmer associations' headquarters lower the likelihood of participation in high-value markets. We also find that better educated farmers are more likely to choose collective marketing channel (MFA).

Our general conclusion is that the farmers' network sizes and collective action significantly influence the adoption of SR production and of a collective marketing channel. Further, we find that participation in a SR farmer association improves livelihoods of rural farming households in the RRD of Vietnam. The findings are in line with those of previous studies in developing countries on SR production and marketing particularly in relation to the effects of social networks and collective action (Bandiera and Rasul, 2006; Maertens and Barrett, 2013; Markelova et al., 2009; Matuschke and Qaim, 2009; Moustier et al., 2010; Rao et al., 2012; Rao and Qaim, 2013; Wollni and Brümmer, 2012).

\subsection{Policy Implications and Further Research}

Our findings have important policy implications on the adoption of SR which are in line with the Vietnamese government's plans to build the country's rice brand by the year 2020, a vision of world leading brand name by the year 2030 (Decision 706/QD-TTg dated May $21,2015)$ and the restructuring strategy for the rice sector in Vietnam (Decision 1898/QDBNN-TT dated May 23, 2016). The implementation of the findings in the first essay lends support to foster the production of SR varieties by strengthening the networks of farmers, especially through participation in SR farmer associations. It is important to strengthen the associations' roles in providing adequate training and increasing interactions between 
members to facilitate information flows on SR production and marketing. The findings in the second essay underline the significant role of SR associations in this endeavor. Collective action via these associations improves rice farm performance (e.g., TE). To enhance their role, the associations should effectively manage their internal control systems to enforce SR quality demanded in the markets. It is important to support SR farmer associations in training farmers on best production practices. Moreover, policy-makers should support farmer associations to better access to quality productive inputs (e.g., seeds, organic fertilizers, pesticides) that benefit smallholder farmers in rural areas.

From the first two essays we suggest that the Government should deregulate the agricultural land market so that farmers can enlarge their cultivated areas (e.g., by buying, renting in or borrowing from others) under SR varieties to increase the level of SR intensity and TE. Lastly, from the third essay, it can be derived that MFA has a significant positive influence on marketing performance. The channel offers better prices to rice farmers than TMC. From a marketing perspective, we recommend that the local authorities should invest more in the specialized organizations in order to enhance their capacity for long-term development. In addition, policy-makers should provide more credit or loan to SR farmer associations to strengthen their new marketing channels and also support them with market information efficiently.

We acknowledge some limitations of our study. In the dissertation, we analyzed the determinants of adoption of SR varieties using network size as main variable of interest. Future studies could include network density and network strengths as main variables of interest to capture how rice farmers use their networks to exchange information such as the frequency and importance of the SR production strategies. In future follow-up studies, it would be interesting to analyze the intensity of participation in SR farmer associations that might affect their members' performance. The influence of duration of participation on farmers' technical efficiency and intensity of adoption is not clear and future studies could also focus on that. However, this requires sample sizes larger than we had. 
Overall, this dissertation points out the importance of adoption of SR in developing countries context using insights from Vietnam. Analyzing long-term impacts of SR adoption, collective action, farmers' choice of marketing channels and on farmers' welfare by using panel data would be important. Consumers' willingness to pay and their preferences for any of the certified SR products would also be interesting to analyze. It is also important to conduct price-spread and price transmission analyzes along the SR value chain to determine the distribution of premiums among the chain actors. 


\section{References}

Abdulai, A. and Eberlin, R. (2001) 'Technical efficiency during economic reform in Nicaragua: Evidence from farm household survey data', Economic Systems, vol. 25, no. 2, pp. 113-125.

Abdul-Salam, Y. and Phimister, E. (2016) 'Efficiency Effects of Access to Information on Smallscale Agriculture: Empirical Evidence from Uganda using Stochastic Frontier and IRT Models', Journal of Agricultural Economics.

ADB (2012) ASEAN and Global Rice Situation and Outlook [Online], ADB. Available at http:// www.adb.org/publications/asean-and-global-rice-situation-and-outlook (Accessed 20 May 2015).

Adedeji, T. O., Nosiru, M. O., Akinsulu, A. A., Ewebiyi, I. O., Abiona, B. G. and Jimoh, T. S. (2013) 'Adoption of New Rice for Africa (NERICA) technology in Ogun State, Nigeria', Journal of Development and Agricultural Economics, vol. 5, no. 9, pp. 365-371.

Adjao, R. T. and Staatz, J. M. (2015) 'Asian rice economy changes and implications for subSaharan Africa', Global Food Security, vol. 5, pp. 50-55.

Ali, M. and Flinn, J. C. (1989) 'Profit Efficiency among Basmati Rice Producers in Pakistan Punjab’, American Journal of Agricultural Economics, vol. 71, no. 2, p. 303.

Bandiera, O. and Rasul, I. (2006) 'Social Networks and Technology Adoption in Northern Mozambique’, The Economic Journal, vol. 116, no. 514, pp. 869-902.

Barham, J. and Chitemi, C. (2009) 'Collective action initiatives to improve marketing performance: Lessons from farmer groups in Tanzania’, Food Policy, vol. 34, no. 1, pp. 53-59.

Barrett, C. B. (2008) 'Smallholder market participation: Concepts and evidence from eastern and southern Africa’, Food Policy, vol. 33, no. 4, pp. 299-317.

Batie, S. S. and Taylor, D. B. (1989) 'Widespread adoption of non-conventional agriculture: Profitability and impacts’, American Journal of Alternative Agriculture, vol. 4, 3-4, p. 128.

Battese, G. E. and Broca, S. S. (1997) 'Functional Forms of Stochastic Frontier Production Functions and Models for Technical Inefficiency Effects: A Comparative Study for Wheat Farmers in Pakistan', Journal of Productivity Analysis, vol. 8, no. 4, pp. 395-414. 
Bavorova, M., Curtiss, J. and Jelinek, L. (2005) Czech Agricultural Associations and the Impact of Membership on Farm Efficiency [Online], Paper prepared for presentation at the 94th EAAE Seminar, The 94th EAAE Seminar, Ashford (UK), 9-10 April 2005.

Bernard, T. and Spielman, D. J. (2009) 'Reaching the rural poor through rural producer organizations?: A study of agricultural marketing cooperatives in Ethiopia’, Food Policy, vol. 34, no. 1, pp. 60-69.

Biénabe, E. and Marie-Vivien, D. (2015) 'Institutionalizing Geographical Indications in Southern Countries: Lessons Learned from Basmati and Rooibos’, World Development.

Blandon, J., Henson, S. and Islam, T. (2009) 'Marketing preferences of small-scale farmers in the context of new agrifood systems: A stated choice model', Agribusiness, vol. 25, no. 2, pp. 251267.

Brent, W., Knodel, J. E. and Sittitrai, W. (1991) Focus Groups and Surveys as Complementary Research Methods: Examples from a Study of the Consequences of Family Size in Thailand [Online], University of Michigan and PSC Research Report No. 91-213. May 1991. Available at http://www.psc.isr.umich.edu/pubs/abs/857 (Accessed 10 September 2015).

Bui, T. T., Pham, C. N. and Ung, T. H. N. (2009) Promoting quality and marketing for Hoa Vang sticky rice in An Phu commune, Kinh Mon district, Hai Duong province: Linking small-scale farmers to supermarkets and other quality chains [Online], Hanoi, CIRAD.

Cazzuffi, C. and McKay, A. (2012) Rice market participation and channels of sale in rural Vietnam [Online], Brazil, The International Association of Agricultural Economists. Available at http://ageconsearch.umn.edu/handle/126566 (Accessed 18 May 2015).

Chaudhary, R. (2003) Speciality rices of the world: Effect of WTO and IPR on its production trend and marketing | WFL Publisher [Online]. Available at http://world-food.net/specialityrices-of-the-world-effect-of-wto-and-ipr-on-its-production-trend-and-marketing/ (Accessed 18 May 2015).

Coelli, T. J. and Battese, G. E. (1996) 'IDENTIFICATION OF FACTORS WHICH INFLUENCE THE TECHNICAL INEFFICIENCY OF INDIAN FARMERS', Australian Journal of Agricultural Economics, vol. 40, no. 2, pp. 103-128.

Coelli, T. J., Rao, D., O'Donnell, C. and Battese, G. E. (2005) An Introduction to Efficiency and Productivity Analysis, New York, Springer-Verlag. 
Corsi, A., Borsotto, P., Borri, I. and Strøm, S. (2009) Diversification of the marketing chains among organic producers [Online], Contributed Paper prepared for presentation at the International Association of Agricultural.

Coxhead, I., Linh, V. H. and Le Tam, D. (2012) 'Global market shocks and poverty in Vietnam: The case of rice’, Agricultural Economics, vol. 43, no. 5, pp. 575-592.

Dao, T. A. and Pham, C. (2013) Conservation and development of local Hoa Vang sticky rice with Collective trademark as a common property of Kinh Mon district, Hai Duong province [Online], Hanoi, Centre for Agrarian Systems Research and Development.

Dao, T. A. and Sautier, D. (2011) Local Food Systems in Vietnam: Strengths and Opportunities [Online] (Food and Fertilizer Technology Center (640)). Available at http://www.fftc.agnet.org/ library.php?func=view\&style=type\&id=20131024113041.

Dawe, D., Robertson, R. and Unnevehr, L. (2002) 'Golden rice: What role could it play in alleviation of vitamin A deficiency?’, Food Policy, vol. 27, 5-6, pp. 541-560.

Deininger, K. (1995) 'Collective agricultural production: A solution for transition economies?', World Development, vol. 23, no. 8, pp. 1317-1334.

Escobal, J. A. and Cavero, D. (2012) 'Transaction Costs, Institutional Arrangements and Inequality Outcomes: Potato Marketing by Small Producers in Rural Peru', World Development, vol. 40, no. 2, pp. 329-341.

Fafchamps, M. and Hill, R. V. (2005) 'Selling at the Farmgate or Traveling to Market', American Journal of Agricultural Economics, vol. 87, no. 3, pp. 717-734.

FAO (2006) International commodity profile [Online]. Available at https://scholar.google.de/ scholar?ion=1\&espv=2\&bav=on.2,or.r_cp.\&bvm=bv.93990622,d.bGg\&biw=1366\&bih=683\&dp $\mathrm{r}=1 \& u m=1 \& i e=U T F-8 \& l r \& q=$ related:miBGI8fLuuOgKM:scholar.google.com/ （Accessed 25 May 2015).

FAO (2014) A regional rice strategy for sustainable food security in Asia and the Pacific, Bangkok, Food and Africulture Organization of the United Nations Regional Office for Asia and the Pacific.

FAOSTAT (2015) FAOSTAT3 [Online]. Available at http://faostat3.fao.org/download/Q/QC/E (Accessed May 2015). 
Farrell, M. J. (1957) 'The Measurement of Productive Efficiency', Journal of the Royal Statistical Society. Series A (General), vol. 120, no. 3, p. 253.

Feder, G., Just, R. E. and Zilberman, D. (1982) Adoption of agricultural innovation in developing countries: A survey / Gershon Feder, Richard E. Just, David Zilberman, Washington, D.C., World Bank.

Fischer, E. and Qaim, M. (2012) 'Linking Smallholders to Markets: Determinants and Impacts of Farmer Collective Action in Kenya’, World Development, vol. 40, no. 6, pp. 1255-1268.

Fischer, E. and Qaim, M. (2014) 'Smallholder Farmers and Collective Action: What Determines the Intensity of Participation?', Journal of Agricultural Economics, vol. 65, no. 3, pp. 683-702.

Frédéric, T. and Dao, T. A. (2005) Community biodiversity management 207-212: Promoting resilience and the conservation of plant genetic resources / edited by Walter Simon de Boef, Nivaldo Peroni, Abishkar Subedi, Marja Helen Thijssen, and Elizabeth O'Keeffe.

Gedara, K. M., Wilson, C., Pascoe, S. and Robinson, T. (2012) 'Factors Affecting Technical Efficiency of Rice Farmers in Village Reservoir Irrigation Systems of Sri Lanka', Journal of Agricultural Economics, vol. 63, no. 3, pp. 627-638.

Ghani, M. A., Jeffrey, C. M. and Salinger, B. L. (1993) 'Diversification Within Rice: Production Opportunities and Export Prospects of Specialty Rice in Bangladesh', XXI, no. 3 [Online]. Available at http://www.jstor.org/stable/40795483 (Accessed 15 May 2015).

Giraud, G. (2013) The World Market of Fragrant Rice, Main Issues and Perspectives [Online], International Food and Agribusiness Management Review>Volume 16, Issue 2, 2013. Available at http://ageconsearch.umn.edu/handle/148577 (Accessed 18 May 2015).

Goetz, S. J. (1992) 'A Selectivity Model of Household Food Marketing Behavior in Sub-Saharan Africa’, American Journal of Agricultural Economics, vol. 74, no. 2, p. 444.

Greene, W. H. (2012) Econometric analysis, 7th edn, Boston, Pearson.

GRiSP (2013) Rice almanac: Source book for the most important economic activities on Earth, Los Baños Philippines, IRRI.

Gross, B. L. and Zhao, Z. (2014) 'Archaeological and genetic insights into the origins of domesticated rice', Proceedings of the National Academy of Sciences, vol. 111, no. 17, pp. 61906197. 
GSO (2014) Statistical handbook of Vietnam [Online], Hanoi.

GSO (2015) Statistic Yearbook of Vietnam [Online], Hanoi.

Gulati, A., Minot, N., Delgado, C. and Bora, S. (2005) Growth in high-value agriculture in Asia and the emergence of vertical links with farmers [Online], World Bank. Available at http:// siteresources.worldbank.org/INTRANETTRADE/Resources/Topics/Standards/paper_minot.pdf (Accessed 8 September 2015).

Hoang, H. K. and Meyers, W. H. (2015) 'Price stabilization and impacts of trade liberalization in the Southeast Asian rice market’, Food Policy, vol. 57, pp. 26-39.

Hoang, L. A., Castella, J.-C. and Novosad, P. (2006) 'Social networks and information access: Implications for agricultural extension in a rice farming community in northern Vietnam', Agriculture and Human Values, vol. 23, no. 4, pp. 513-527.

Hoang, V. L. and Yabe, M. (2012) Impact of Environmental Factors on Profit Efficiency of Rice Production: A Study in Vietnam's Red River Delta [Online] (World Academy of Science, Engineering and Technology 66).

Hoang, V.-N. (2013) 'Analysis of productive performance of crop production systems: An integrated analytical framework’, Agricultural Systems, vol. 116, pp. 16-24.

Hoff, K., Braverman, A. and Stiglitz, J. E. (1993) The Economics of rural organization: Theory, practice, and policy / edited by Karla Hoff, Avishay Braverman, and Joseph E. Stiglitz, Oxford, published for the World Bank [by] Oxford University Press.

HSO (2013) Haiduong Statistical Yearbook 2013 [Online], Statistical publishing house.

Huynh, V. K. and Yabe, M. (2011) Technical efficiency analysis of rice production in Vietnam [Online] (J.ISSAAS.17, No. 1).

IRRI (2003) Hybrid rice for food security, poverty alleviation, and environmental protection, Metro Manila Philippines, IRRI.

ISO (2011) ISO 7301:2011 - Rice -- Specification [Online]. Available at http://www.iso.org/iso/ catalogue_detail.htm?csnumber=50935 (Accessed 25 May 2015).

Jaenicke, Hannah, Dao, T. A. and Pham, C. (2010) Harnessing local underused crops to improve household nutrition and income opportunities in Vietnam: case of Hoa vang sticky rice in Red 
river delta [Online], European Association of Agricultural Economists. Available at http:// econpapers.repec.org/paper/agseaa116/95038.htm (Accessed 20 May 2015).

Jamora, N. and Cramon-Taubadel, S. v. (2012) What world price?: Georg-August-Universität Göttingen - GlobalFood Discussion Paper Series No.17 [Online]. Available at https://www.unigoettingen.de/en/213486.html (Accessed 20 May 2015).

Jena, P. R. and Grote, U. (2012) 'Impact Evaluation of Traditional Basmati Rice Cultivation in Uttarakhand State of Northern India: What Implications Does It Hold for Geographical Indications?', World Development, vol. 40, no. 9, pp. 1895-1907.

Johnston, R. J., Weaver, T. F., Smith, L. A. and Swallow (1995) Contingent Valuation Focus Groups: Insights From Ethnographic Interview Techniques [Online], Agricultural and Resource Economics Review>Volume 24, Number 1, April 1995. Available at http://purl.umn.edu/31460 (Accessed 10 September 2015).

Josling, T. (2006) 'The War on Terroir: Geographical Indications as a Transatlantic Trade Conflict', Journal of Agricultural Economics, vol. 57, no. 3, pp. 337-363.

Kersting, S. and Wollni, M. (2012) 'New institutional arrangements and standard adoption: Evidence from small-scale fruit and vegetable farmers in Thailand', Food Policy, vol. 37, no. 4, pp. 452-462.

Kijima, Y., Otsuka, K. and Sserunkuuma, D. (2008) 'Assessing the impact of NERICA on income and poverty in central and western Uganda', Agricultural Economics, vol. 38, no. 3, pp. 327-337.

Kijima, Y. and Sserunkuuma, D. (2013) 'The adoption of NERICA rice varieties at the initial stage of the diffusion process in Uganda', 2013 [Online]. Available at http:// ageconsearch.umn.edu/bitstream/156984/2/

4.\%20Kijima,\%20Sserunkuuma\%20NERICA\%20adoption.pdf.

Kompas, T. (2002) Market Reform, Productivity and Efficiency in Vietnamese Rice Production [Online] (International and Development Economics Paper 04-4. Canberra, ACT: Crawford School of Economics and Government, The Australian National University).

Latynskiy, E. and Berger, T. (2016) 'Networks of Rural Producer Organizations in Uganda: What Can be Done to Make Them Work Better?’, World Development, vol. 78, pp. 572-586. 
Le, H. T. (2009) Collective action in Hoa Vang and Hai Hau Tam Xoan rice organizations: Linking small-scale farmers to supermarkets and other quality chains [Online], Hanoi, CIRAD.

Lin, J. Y. (1991) 'Education and Innovation Adoption in Agriculture: Evidence from Hybrid Rice in China', American Journal of Agricultural Economics, vol. 73, no. 3, p. 713.

Maclean, J. L. (2002) Rice almanac: Source book for the most important economic activity on earth / edited by J.L. Maclean ... [et al.], 3rd edn, Wallingford, CABI Pub.

Maertens, A. and Barrett, C. B. (2013) 'Measuring Social Networks' Effects on Agricultural Technology Adoption’, American Journal of Agricultural Economics, vol. 95, no. 2, pp. 353-359.

Markelova, H., Meinzen-Dick, R., Hellin, J. and Dohrn, S. (2009) 'Collective action for smallholder market access', Food Policy, vol. 34, no. 1, pp. 1-7.

Marsden, P. V. (1990) 'Network Data and Measurement', Annual Review of Sociology, vol. 16, no. 1 , pp. 435-463.

Matuschke, I. and Qaim, M. (2009) 'The impact of social networks on hybrid seed adoption in India’, Agricultural Economics, vol. 40.

Meinzen-Dick, R. and Di Gregorio, M. (2004) Collective action and property rights for sustainable development [Online], Washington, D.C., IFPRI (2020 Vision for food, agriculture and the environment. Focus 11).

Minot, N. and Goletti, F. (2000) Rice market liberalization and poverty in Viet Nam, Washington, D.C., International Food Policy Research Institute.

Moser, C. M. and Barrett, C. B. (2006) 'The complex dynamics of smallholder technology adoption: the case of SRI in Madagascar', Agricultural Economics, vol. 35, no. 3, pp. 373-388 [Online]. DOI: 10.1111/j.1574-0862.2006.00169.x.

Mottaleb, K. A., Mohanty, S. and Nelson, A. (2015) 'Factors influencing hybrid rice adoption: A Bangladesh case', Australian Journal of Agricultural and Resource Economics, vol. 59, no. 2, pp. 258-274.

Moustier, P., Phan, T. T., Dao, T. A., Vu, T. B. and Nguyen, T. L. (2010) 'The role of farmer organizations in supplying supermarkets with quality food in Vietnam', Food Policy, vol. 35, no. 1, pp. 69-78. 
Muthayya, S., Sugimoto, J. D., Montgomery, S. and Maberly, G. F. (2014) 'An overview of global rice production, supply, trade, and consumption', Annals of the New York Academy of Sciences, vol. 1324, no. 1, pp. 7-14 [Online]. DOI: 10.1111/nyas.12540.

Narrod, C., Roy, D., Okello, J., Avendaño, B., Rich, K. and Thorat, A. (2009) 'Public-private partnerships and collective action in high value fruit and vegetable supply chains', Food Policy, vol. 34, no. 1 , pp. 8-15.

Ngokkuen, C. and Grote, U. (2012) Geographical Indication for Jasmine Rice: Applying a Logit Model to Predict Adoption Behavior of Thai Farm Households [Online], Quarterly Journal of International Agriculture. Available at http://ageconsearch.umn.edu/handle/155476 (Accessed 18 May 2015).

Nguyen, C. T. and Baldeo, S. (2006) Trend in rice production and export in Vietnam - Google Search [Online]. Available at https://www.google.de/ (Accessed 18 May 2015).

Nguyen, V. C., Tim, McGrath, Tim and Pamela, W. (2010) Agricultural Land Distribution in Vietnam: Emerging Issues and Policy Implications [Online], MRPA Paper No. 25587 (MRPA Paper No. 25587).

Nguyen, V. N. and Ferrero, A. (2006) 'Meeting the challenges of global rice production', Paddy and Water Environment, vol. 4, no. 1, pp. 1-9.

Nielsen, C. P. (2003) 'Vietnam's Rice Policy: Recent Reforms and Future Opportunities', Asian Economic Journal, vol. 17, no. 1, pp. 1-26.

OECD (2015) Agricultural Policies in Viet Nam 2015, Paris, OECD Publishing.

Ouma, E., Jagwe, J., Obare, G. A. and Abele, S. (2010) 'Determinants of smallholder farmers' participation in banana markets in Central Africa: The role of transaction costs', Agricultural Economics, vol. 41, no. 2, pp. 111-122.

Pingali, P. L. and Vo, T. X. (1992) 'Decollectivization and Rice Productivity Growth', Economic Development and Cultural Change, vol. 40, no. 4, pp. 697-718.

QSO (2013) Quangninh Statistical Yearbook 2013 [Online], Statistical publishing house.

Rahm, M. R. and Huffman, W. E. (1984) 'The Adoption of Reduced Tillage: The Role of Human Capital and Other Variables', American Journal of Agricultural Economics, vol. 66, no. 4, p. 405. 
Rahman, S. (2003) 'Profit efficiency among Bangladeshi rice farmers', Food Policy, vol. 28, 5-6, pp. 487-503.

Rahman, S., Wiboonpongse, A., Sriboonchitta, S. and Chaovanapoonphol, Y. (2009) 'Production Efficiency of Jasmine Rice Producers in Northern and North-eastern Thailand', Journal of Agricultural Economics, vol. 60, no. 2, pp. 419-435.

Rao, E. J. and Qaim, M. (2013) 'Supermarkets and agricultural labor demand in Kenya: A gendered perspective’, Food Policy, vol. 38, pp. 165-176.

Rao, E. J. O., Brümmer, B. and Qaim, M. (2012) 'Farmer Participation in Supermarket Channels, Production Technology, and Efficiency: The Case of Vegetables in Kenya', American Journal of Agricultural Economics, vol. 94, no. 4, pp. 891-912.

Reardon, T., Timmer, C. P., Barrett, C. B. and Berdegue, J. (2003) 'The Rise of Supermarkets in Africa, Asia, and Latin America', American Journal of Agricultural Economics, vol. 85, no. 5, pp. 1140-1146.

Rutsaert, P. and Demont, M. (2015) Rice value chain upgrading in Vietnam: Towards increasing sustainability [Online], Milan (International Conference of Agricultural Economists). Available at http://ageconsearch.umn.edu/.

Sharif, N. R. and Dar, A. A. (1996) 'Stochastic Frontiers and Technical Efficiency Distributions: An Analysis Based on Rice Farming Data for Bangladesh’, The Canadian Journal of Economics, vol. 29, pp. S582.

Shiferaw, B., Hellin, J. and Muricho, G. (2011) 'Improving market access and agricultural productivity growth in Africa: What role for producer organizations and collective action institutions?', Food Security, vol. 3, no. 4, pp. 475-489.

Tan, S., Heerink, N., Kuyvenhoven, A. and Qu, F. (2010) 'Impact of land fragmentation on rice producers' technical efficiency in South-East China', NJAS - Wageningen Journal of Life Sciences, vol. 57, no. 2, pp. 117-123.

The Vietnamese Government (2009) Resolution No. 63/NQ-CP dated December 23, 2009 of the Government on national food security [Online], Hanoi.

The Vietnamese Government (2012) Decree No. 42/2012/ND-CP dated May 11, 2012 of the Government on management and use of rice-farming land [Online], Hanoi. 
The Vietnamese Government (2015) Decision No. 706/QD-TTg dated 21/5/2015 approving the master plan for the development of Vietnamese rice brand by 2020 and vision to 2030 [Online], Hanoi.

Thorp, R., Stewart, F. and Heyer, A. (2005) 'When and how far is group formation a route out of chronic poverty?’, World Development, vol. 33, no. 6, pp. 907-920.

Tran, C. T. and Dinh, T. L. (2015) Rice policy Review in Vietnam [Online], Taipei, Taiwan ROC, FFTC Agricultural Policy Articles. Available at http://ap.fftc.agnet.org/.

Tran, C. T. and Vu, H. P. (2016) Vietnam's Rice Policy Review [Online], Taipei, Taiwan ROC, FFTC Agricultural Policy Articles. Available at http://ap.fftc.agnet.org/.

Ulimwengu, J. and Badiane, O. (2010) 'Vocational Training and Agricultural Productivity: Evidence from Rice Production in Vietnam', The Journal of Agricultural Education and Extension, vol. 16, no. 4, pp. 399-411.

United Nations (2011) World Population Prospects: The 2010 Revision [Online], New York. Available at http://www.un.org/en/development/desa/population/publications/.

USDA (2015) Vietnam Grain and Feed Annual [Online], Foreign Agricultural Service (GAIN Report Number: VM5025).

Verbeek, M. (2004) A guide to modern econometrics [Online], 2nd edn, Chichester, John Wiley \& Sons. Available at http://www.loc.gov/catdir/bios/wiley046/2004004222.html.

Vo, H. T. and Nguyen, T. T. (2016) Cost Efficiency of Rice Production in Vietnam: An Application of Stochastic Translog Variable Cost Frontier [Online] (Asian Journal of Agricultural Extension Economics and Sociology 8(1): 1-10, 2016 AJAEES.19745).

$\mathrm{Vu}, \mathrm{H}$. L. (2012) 'Efficiency of rice farming households in Vietnam', International Journal of Development Issues, vol. 11, no. 1, pp. 60-73.

Vuong, Q. D. (2012) The role of access to credit in rice production efficiency of rural households in the Mekong Delta, Vietnam [Online], Centre for ASEAN Studies (CAS Discussion paper No 84).

Wadud, A. and White, B. (2000) 'Farm household efficiency in Bangladesh: A comparison of stochastic frontier and DEA methods', Applied Economics, vol. 32, no. 13, pp. 1665-1673. 
Wellman, B. (1979) 'The Community Question: The Intimate Networks of East Yorkers', American Journal of Sociology, vol. 84, no. 5, pp. 1201-1231.

Williamson, O. E. (1985) The economic institutions of capitalism: firms, markets, relational contracting, New York, The Free Press.

Wollni, M. and Brümmer, B. (2012) 'Productive efficiency of specialty and conventional coffee farmers in Costa Rica: Accounting for technological heterogeneity and self-selection', Food Policy, vol. 37, no. 1, pp. 67-76.

Wollni, M. and Zeller, M. (2007) 'Do farmers benefit from participating in specialty markets and cooperatives?: The case of coffee marketing in Costa Rica1', Agricultural Economics, vol. 37, 23, pp. 243-248.

Wooldridge, J. M. (2010) Econometric analysis of cross section and panel data, 2nd edn, Cambridge, Mass., London, MIT.

Wossen, T., Berger, T. and Di Falco, S. (2015) 'Social capital, risk preference and adoption of improved farm land management practices in Ethiopia’, Agricultural Economics, vol. 46, no. 1, pp. 81-97.

Yamano, T., Arouna, A., Labarta, R. A., Huelgas, Z. M. and Mohanty, S. (2016) 'Adoption and impacts of international rice research technologies’, Global Food Security, vol. 8, pp. 1-8.

Zivenge, E. and Karavina, C. (2012) 'Analysis of factors influencing market channel access by communal horticulture farmers in Chinamora District, Zimbabwe’, Journal of Development and Agricultural Economics, vol. 4, no. 6. 


\section{Appendices}

\section{Appendix 1. The development of SR farmer association in Kinh Mon}

\begin{tabular}{|l|l|c|c|}
\hline Ord. & Indicators/Items & $\begin{array}{l}\text { Number of } \\
\text { active } \\
\text { members }\end{array}$ & Area (ha) \\
\hline 2006 & 1 group & 36 & 2.3 \\
\hline 2007 & 3 groups & 131 & 10 \\
\hline 2008 & Association & 253 & 20 \\
\hline 2009 & Association & 363 & 23.4 \\
\hline 2010 & Association & 367 & 25 \\
\hline 2011 & Association & 367 & 25 \\
\hline 2012 & Association & 367 & 25 \\
\hline 2013 & Association & & 10 \\
\hline
\end{tabular}

(Source: Kinh Mon SR farmer association)

\section{Appendix 2. The development of SR farmer association in Dong Trieu}

\begin{tabular}{|l|l|c|c|}
\hline Ord. & Indicators/Items & $\begin{array}{l}\text { Number of } \\
\text { active } \\
\text { members }\end{array}$ & Area (ha) \\
\hline 2011 & 4 groups & NA & NA \\
\hline 2012 & Association & 630 & 50 \\
\hline 2013 & Association & 881 & 68 \\
\hline
\end{tabular}

(Source: Dong Trieu SR farmer association)

* NA: Not applicable 
Appendix 3. Specialty rice harvested areas in Kinh Mon district

\begin{tabular}{|l|l|c|c|c|c|}
\hline Ord. & Indicators/Items & 2009 & 2010 & 2011 & 2012 \\
\hline 1 & Total harvested areas (ha) & 9,306 & 9,521 & 9,518 & 9,518 \\
\hline 2 & Specialty rice areas (ha) & 590 & 550 & 520 & 515 \\
\hline
\end{tabular}

Source: The Kinh Mon department of agriculture and rural department, 2013

\section{Appendix 4. Average growth rate of rice yield in Vietnam, 1976-2014}

Unit: \%/year

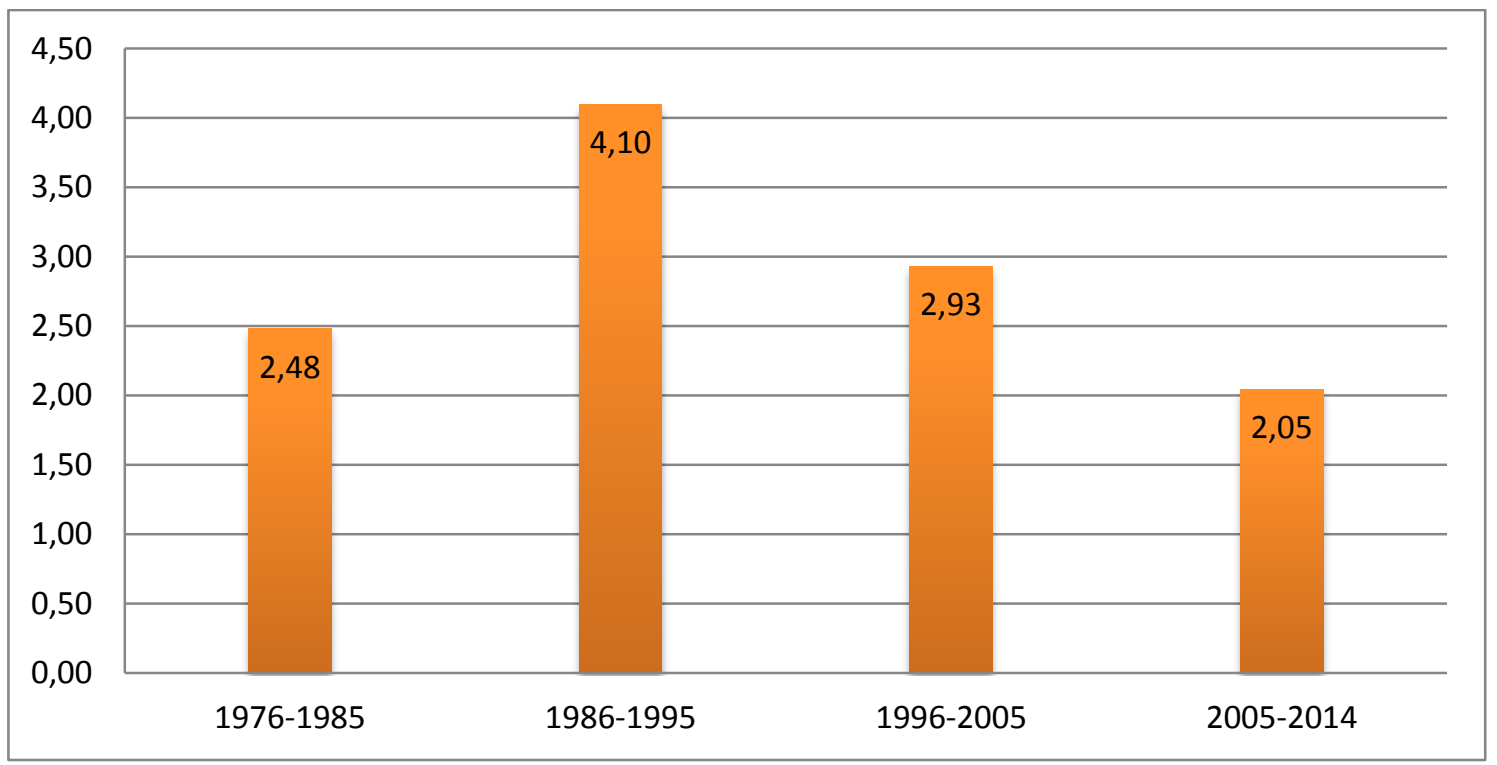

(Source: FAO, World Rice Statistics, 2016) 


\section{Appendix 5. Milled rice production and consumption in Vietnam, 1986- 2013}

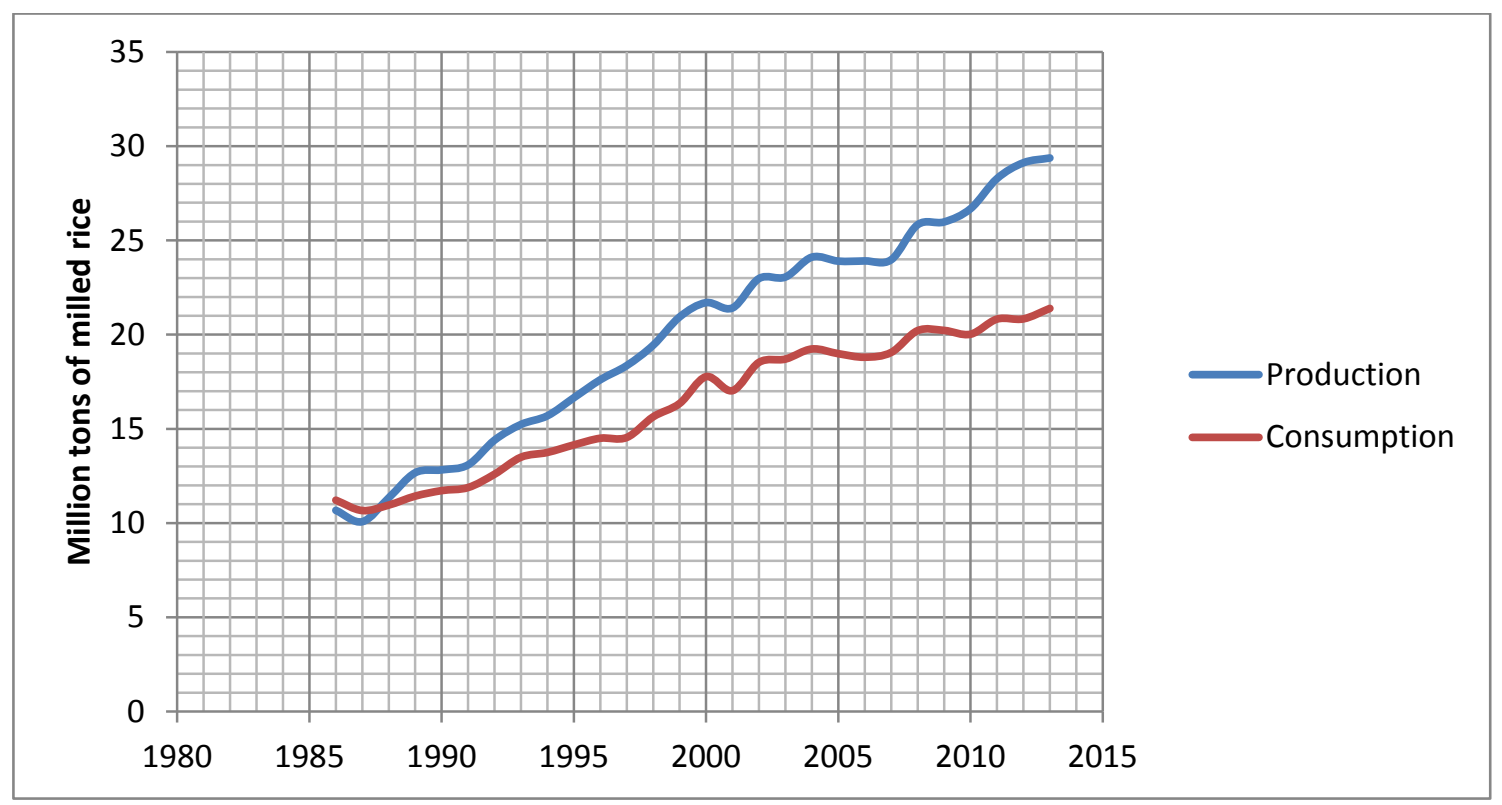

(Source: FAO, World Rice Statistics, 2016)

\section{Appendix 6. List of certified rice varieties in Vietnam (up to date}

\subsubsection{3)}

\begin{tabular}{|c|c|c|}
\hline $\begin{array}{l}\text { Geographical } \\
\text { Indication (04) }\end{array}$ & $\begin{array}{l}\text { Certificated } \\
\text { Marks (03) }\end{array}$ & Collective Marks (21) \\
\hline $\begin{array}{l}\text { Fragrant rice } \\
\text { (Hai Hau, Nam } \\
\text { Dinh); Bay Nui } \\
\text { rice (An Giang); } \\
\text { Dien Bien rice } \\
\text { (Dien Bien); } \\
\text { Hong Dan rice } \\
\text { (Bac Lieu) }\end{array}$ & $\begin{array}{l}\text { G HB Huong } \\
\text { Binh rice } \\
\text { (Ninh Binh); } \\
\text { HDPC high- } \\
\text { quality rice } \\
\text { (Ha Noi); ST } \\
\text { fragrant rice } \\
\text { (Soc Trang) }\end{array}$ & $\begin{array}{l}\text { High-quality rice and fragrant sticky rice (Bac Quang, } \\
\text { Ha Giang); fragrant rice (Long An); Bo Nau rice (Ha } \\
\text { Noi); Quang Dien red rice (in Hue); hoa vang sticky } \\
\text { rice (Quang Ninh); glutinous rice (An Giang); fragrant } \\
\text { rice (An Giang); Phu Tan sticky rice (An Giang); Tu } \\
\text { Le sticky rice (Yen Bai); high-quality rice with } \\
\text { GlobalGAP (Tien Giang); GDH Bao Thai (Tuyen } \\
\text { Quang); Long Trifragrant rice (Vinh Phuc); sticky rice } \\
\text { (Bac Giang); HG2 specialty paddy (Hau Giang); Cat } \\
\text { Tien rice (Lam Dong); My Lung sticky rice (Phu Tho); } \\
\text { Yen Dung fragrant rice (Bac Giang); Cho Don rice } \\
\text { (Bac Kan); VM rice (An Giang); Kinh Mon sticky rice } \\
\text { (Hai Duong); Thau Dau sticky rice (Thai Nguyen); }\end{array}$ \\
\hline
\end{tabular}

Source: National Office of Intellectual Property of Vietnam, 2013 
Appendix 7. Distribution of share of SR area adopted in total cultivated rice area

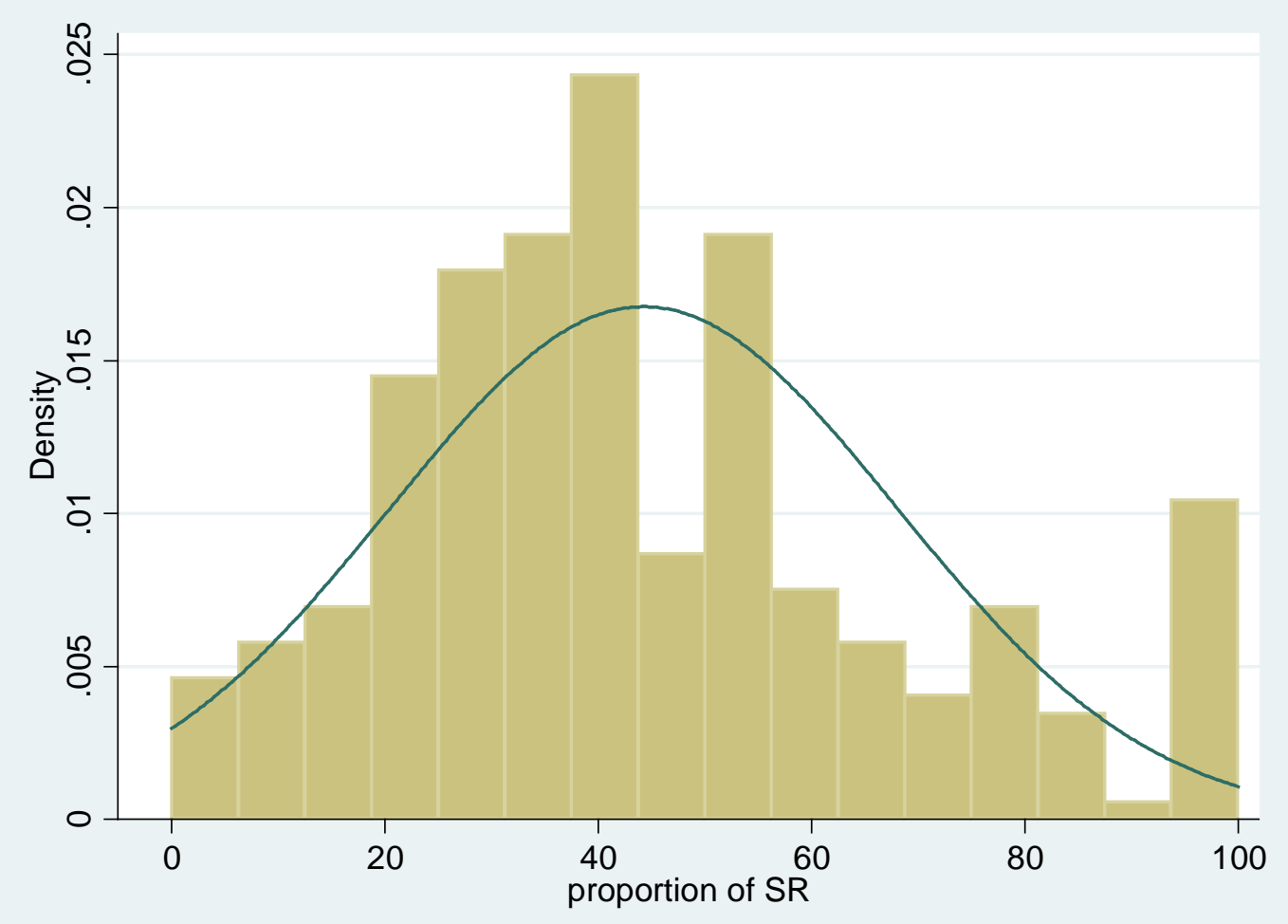




\section{Appendix 8. Type of collective actions in SR production}

\begin{tabular}{|c|c|c|}
\hline Order & Collective actions & Who involved in \\
\hline 1 & $\begin{array}{l}\text { Collection of accessions and social reconstruction } \\
\text { of the variety to choose the best quality seeds in } \\
\text { terms of aromatic and taste); } \\
\text { To produce quality specialty rice for the local } \\
\text { community; to build a set of SR standard }\end{array}$ & $\begin{array}{l}\text { Experienced farmers and } \\
\text { agronomists, geneticists. }\end{array}$ \\
\hline 2 & To create the protocol to produce SR varieties; & $\begin{array}{l}\text { Pioneer farmers and } \\
\text { geneticists. }\end{array}$ \\
\hline 3 & $\begin{array}{l}\text { To buy inputs (fertilizers and pesticides) } \\
\text { collectively helps to reduce cost and ensure quality. }\end{array}$ & $\begin{array}{l}\text { Members, leaders of SR } \\
\text { farmer associations. }\end{array}$ \\
\hline 4 & Training activities for members & Members and agronomists. \\
\hline 5 & $\begin{array}{l}\text { Marketing through collective actions; } \\
\text { Organizing central rice processing where SR } \\
\text { products were milled, sorted then packed with } \\
\text { collective mark. } \\
\text { Register SR varieties under collective mark as a } \\
\text { common property of local communities. }\end{array}$ & $\begin{array}{l}\text { Members, leaders of SR } \\
\text { farmer associations, and } \\
\text { agronomists. }\end{array}$ \\
\hline 6 & $\begin{array}{l}\text { Quality internal control system has run to ensure } \\
\text { labelled products meet quality standard of the SR } \\
\text { associations from production process to end- } \\
\text { consumers }\end{array}$ & $\begin{array}{l}\text { Members, leaders of SR } \\
\text { farmer associations. }\end{array}$ \\
\hline
\end{tabular}

(Source: Dong Trieu and Kinh Mon SR farmer associations) 
Questionnaires

\title{
Appendix 9. Focus Group Questionnaire
}

\author{
Georg-August-Universität
Göttingen
}

\section{GlobalFood}

\section{Goettingen UniversitylDepartment of Agricultural Economics and Rural Development GlobalFood Training Group}

\section{Specialty rice production and farmer association in the Red River Delta, Vietnam 2014}

(Focus Group Discussion Questionnaire)

Adapted from WB questionnaire about Groups and Networks

We are part of a team a Georg-August-University of Goettingen, who are interested in all of activities relate to rice production in the household level data. You have been selected to participate in the interview which contains questions including farmer characteristics, specialty rice production and marketing, specialized market, membership in farmer organization and its impacts on household income. Thank you very much for your information.

We assure that all of your information during this interview will be kept confidentially. It will take roundly 1 hour to finish the questionnaire. If you indicate your voluntary consent by participating in this interview, may we begin?

If you have any questions or comments regarding to this survey, you can contact to Mr. Thai Thuy Pham via cell phone: 0914365007 or email: phamthaithuy2013@gmail.com

Code of household (copy from face-to-face questionnaire)

\section{A. Specialty rice production}

\begin{tabular}{|c|l|c|c|}
\hline Code & Items & Code & Mark \\
\hline A01 & $\begin{array}{l}\text { Is there any change in using land for rice production in comparison with the last 5 } \\
\text { year? [1] Increase; [2] Decrease; [3] No change }\end{array}$ & A01 & \\
\hline A02 & $\begin{array}{l}\text { Do households prefer to plant hybrid or specialty rice varieties in this area (the } \\
\text { summer - spring season 2014)? } \\
{[1] \text { Hybrid; [2] Specialty rice; [3] Not sure }}\end{array}$ & A02 \\
\hline A03 & $\begin{array}{l}\text { On a scale of 5 point, how significant are the following factors in terms of limiting } \\
\text { specialty rice productivity? } \\
{[1] \text { Very unimportant; [2] Slightly unimportant; [3] Neither important nor unimportant; }} \\
\text { [4] Slightly important; [5] Very important }\end{array}$ & A03 & \\
\hline a & Soil quality/degradation & & \\
\hline b & Lack of quality seed & & \\
\hline C & Lack of access to input (fertilizer, pesticide) & & \\
\hline d & Lack of access to market for outputs & & \\
\hline e & Flooding & \\
\hline f & Drought & \\
\hline
\end{tabular}


Questionnaires

\begin{tabular}{|c|c|c|}
\hline$g$ & Pest damage & \\
\hline $\mathrm{h}$ & Lack of credit & \\
\hline A04 & $\begin{array}{l}\text { Has the use of chemical fertilizer in this area changed? } \\
\text { [1] Increase; [2] Decrease; [3] No change }\end{array}$ & A04 \\
\hline A05 & $\begin{array}{l}\text { Compared to } 5 \text { years ago, how do you rate the quality of farm land in this area } \\
\text { today? } \\
\text { [1] Very low; [2] Low; [3] No change; [4] High; [5] Very high }\end{array}$ & A05 \\
\hline A06 & $\begin{array}{l}\text { Could households in this area obtain more land suitable for specialty rice production } \\
\text { if they wanted it? [1] Yes; [2] No; }\end{array}$ & A06 \\
\hline $\mathrm{A} 07$ & $\begin{array}{l}\text { If no, list the main reasons? [1] None available land nearby; [2] Not allow to rent in; [3] Lack of money; [4] } \\
\text { Government regulations; [5] Other (specify) }\end{array}$ & $\mathrm{A} 07$ \\
\hline A08 & $\begin{array}{l}\text { Are there many households currently obtaining more land in this area to produce } \\
\text { specialty rice? [1] Yes; [2] No; }\end{array}$ & A08 \\
\hline A09 & $\begin{array}{l}\text { If yes, how are they obtaining it? [1] Allocation by local authorities; [2] Buying land; } \\
\text { [3] Renting in; [4] Get free from other households; [5] Other (specify) }\end{array}$ & A09 \\
\hline
\end{tabular}

\section{B. Market Access}

\begin{tabular}{|c|l|c|c|}
\hline Code & Items & Code & Mark \\
\hline B01 & $\begin{array}{l}\text { This past year, roughly how many traders came into the village to buy grain from } \\
\text { farmers in this area? }\end{array}$ & $\mathbf{B 0 1}$ & \\
\hline $\mathbf{B 0 2}$ & $\begin{array}{l}\text { Compared to } 5 \text { years ago, are there more or less traders come into the village } \\
{[1] \text { More; [2] Less; [3] About the same }}\end{array}$ & $\mathbf{B 0 2}$ & \\
\hline B03 & $\begin{array}{l}\text { Do you feel like the suppliers have the inputs that you need at the right time of the } \\
\text { year/season? [1] Yes; [2] No; }\end{array}$ & $\mathbf{B 0 3}$ & \\
\hline
\end{tabular}

\section{Non-farm income}

\begin{tabular}{|c|l|c|c|}
\hline Code & Items & Code & Mark \\
\hline $\mathbf{C 0 1}$ & $\begin{array}{l}\text { How important non-farm activities are? [1] Very unimportant; [2] Slightly unimportant; [3] Neither } \\
\text { important nor unimportant; } \\
\text { [4] Slightly important; [5] Very important }\end{array}$ & $\mathbf{C 0 1}$ & \\
\hline $\mathbf{C 0 2}$ & $\begin{array}{l}\text { Compared to 5 years ago, are there more or less opportunities for off-farm } \\
\text { employment in this area? } \\
\text { [1] More; [2] Less; [3] About the same }\end{array}$ & $\mathbf{C 0 2}$ \\
\hline $\mathbf{C 0 3}$ & $\begin{array}{l}\text { Have people been migrating out of this area seasonally over last 5 years? } \\
{[1] \text { Yes; [2] No; }} \\
\text { How would you describe the seasonal migration trends over the last 5 years? } \\
{[1] \text { Been increasing; [2] Stay about the same; [3] Declining }}\end{array}$ & $\mathbf{C 0 3}$ & $\mathbf{C 0 4}$ \\
\hline $\mathbf{C 0 5}$ & $\begin{array}{l}\text { Why do they leave for doing non-farm activities (please choose the most relevant } \\
\text { reason)? [1] Lack of employment in this area; [2] Lack of access to farm land; [3] Lack of access to education; } \\
\text { [4] Lack of access to other services; [5] Other (specify) }\end{array}$ & $\mathbf{C 0 5}$ & \\
\hline $\mathbf{C 0 6}$ & $\begin{array}{l}\text { List in order of importance the main non-farm activities that people engage in this } \\
\text { area? [1] Self-employed (trading, processing, carpentry, building,...); [2] Government wage employment; [3] } \\
\text { Other (specify) }\end{array}$ & $\mathbf{C 0 6}$ & \\
\hline
\end{tabular}


Questionnaires

D. Farmer association

\begin{tabular}{|c|l|c|c|}
\hline Code & Items & Code & Mark \\
\hline D01 & $\begin{array}{l}\text { What is the main benefit from joining this group? (please choose the most suitable } \\
\text { option) [1] Imporve my household's current livelihood or access to services; [2] Important in times of } \\
\text { emergencylin future; [3] Benefits the community; [4] Enjoymentrecreation; [5] Spirtual, social status, self-esteem; } \\
\text { [6] Other (specify) }\end{array}$ & D01 & \\
\hline D02 & $\begin{array}{l}\text { When there is a decision to be made in the group, how does this usually come } \\
\text { about? [1] Decision is imposed from outside; [2] The leader decides and informs the other group members; } \\
\text { [3]The leaders asks group members what they think and then decides; [4] The group members hold a discussion } \\
\text { and decide together; [5] Other (specify) }\end{array}$ & D02 & \\
\hline D03 & $\begin{array}{l}\text { Overall, how effective is the group's leadership? [1] Very effective; [2] Somewhat effective; [3] } \\
\text { Not effective }\end{array}$ & D03 & \\
\hline D04 & $\begin{array}{l}\text { Does this group work or interact with other groups with similar goals in the } \\
\text { village/neighborhood? [1] No; [2] Yes, occationally; [3] Yes, frequently }\end{array}$ & D04 & \\
\hline D05 & $\begin{array}{l}\text { What is the most important source of funding of this group? [1] From members' dues; Other } \\
\text { sources within the community; [3] From source outside the community }\end{array}$ & D05 & \\
\hline D06 & Do you agree with these statement following? & & \\
\hline a & Sell to the cooperative even if other firm offers better price [1] Yes; [2] No & & \\
\hline b & Better price is better than relationships with the cooperative [1] Yes; [2] No & & \\
\hline C & Willingness to invest if the cooperative requires [1] Yes; [2] No & & \\
\hline d & Willingness to receive lower price temparorily [1] Yes; [2] No & & \\
\hline e & cooperative's future is part of concerns [1] Yes; [2] No & & \\
\hline f & Willingness to wait for delay payment for short-time [1] Yes; [2] No & & \\
\hline g & Satisfaction with price the cooperative pays for the product [1] Yes; [2] No & \\
\hline h & Cooperative monitors rigously productive activity on site [1] Yes; [2] No & \\
\hline
\end{tabular}

\section{Appendix 10. Household Questionnaire 2014}




\section{Georg-August-Universität \\ Göttingen \\ HOUSEHOLD QUESTIONNAIRE 2014 \\ SPECIALTY RICE PRODUCTION AND FARMER ORGANIZATION IN THE RED RIVER DELTA OF VIETNAM}

\section{GlobalFood}

\section{Introduction}

We are PhD-students from Georg-August- University of Goettingen in Germany, who are interested in all of activities relating to rice production in the household level. You have been randomly selected to participate in the interview which contains questions connect with farmer characteristics, specialty rice production and marketing, membership in farmer association (FA) and its impacts on household welfare. Thank you very much for your information.

We assure that all of your information during this interview will be kept confidentially, only using for research purposes. It will take roundly 2 hours to finish the questionnaire. If you indicate your voluntary consent by participating in this interview, may we begin? If you have any questions or comments about this survey, you may contact Mr. Thai Thuy Pham; Cell phone: 0914365007 or email: phamthaithuy2013@gmail.com

Enumerator and Supervisor Details:

Enumerator: Name

Supervisor: Name

Entry data clerk name

Module 1: Survey information

Module 2: Household characteristics

Module 3: Tenure and farm production

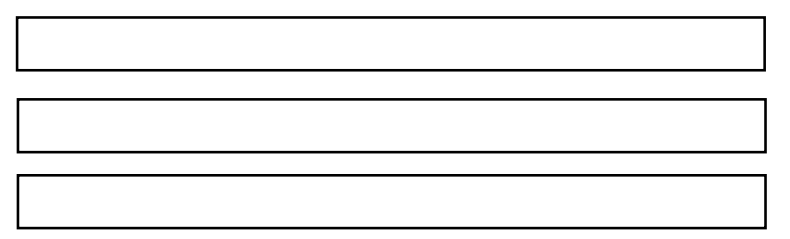

ENUM

Signature/date

DNUM

Module 4: Household assets

Page 1

Module 7: The role of rice farmer association

Module 8: Credit

Module 9: Extension and training activities

Module 10: Shocks

Module 11: Social networks and trust

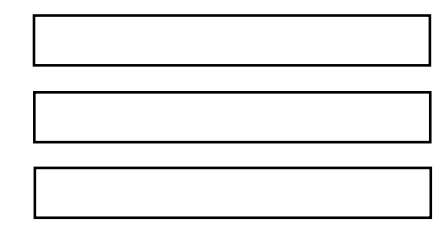

Page 2

Page $\quad 3-7$

Module 5: Non-farm income

Page 9

Module 6: Specialty rice production and marketing

Page 10-11

Module 12: Willingness to pay for membership fee

Module 13: Consumption and expenditure
Page 12

Page 13

Page 13

Page 14

Page 15

Page 15

Page 16 


\section{MODULE 1. SURVEY INFORMATION}

1.1. Province (PROV) ([1] Hai Duong; [2] Quang Ninh)

1.2. District (DIST) ([1] Kinh Mon; [2] Dong Trieu)

1.3. Commune (COMM)

1.4. Village (VILL)

1.8. Name of the head of household (HENAME):

1.10. Name of respondent (RNAME):

(HRELA)

1.12. Did your household produce specialty rice in 2014 (SPERICE) ([1] Yes; [2] No)

1.12.1. Is the household is a current member of the FA (MEMASSO)?

([1] Yes [2] No)

1.12.3. Who is the most actively participant in FA (ACTIVE)?

1.13. Which year did your household start farming in this village* (FARMYEAR)?

1.14.Mobile phone number:

1.16. Distance to central market (DISTANCE) (m)

Ref. Period from 1st July 2013 to 30 June 2014

Focused on Hoa Vang sticky rice

${ }^{*}$ As an independent household

Code A: [1] Head; [2] Wife/Husband; [3] Son/Daughter; [4] Son/Daughter in law; [5] Father/Mother; [6] Father/Mother in law; [7] Sister/Brother; [8] Grandchild; [9] Other relatives; [10] № answer; [99] Not applicable

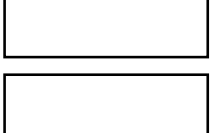

1.12.2. Year household joined the FA (FAYEAR):

SURINFOR

1.5. Date of the interview (INDATE):

1.6. Time started (STIME):

1.7. Time finished (FTIME):

1.9. Sex of the household head (HESEX) [1] male [2] female)

1.11- Relationship to household head (Code A)
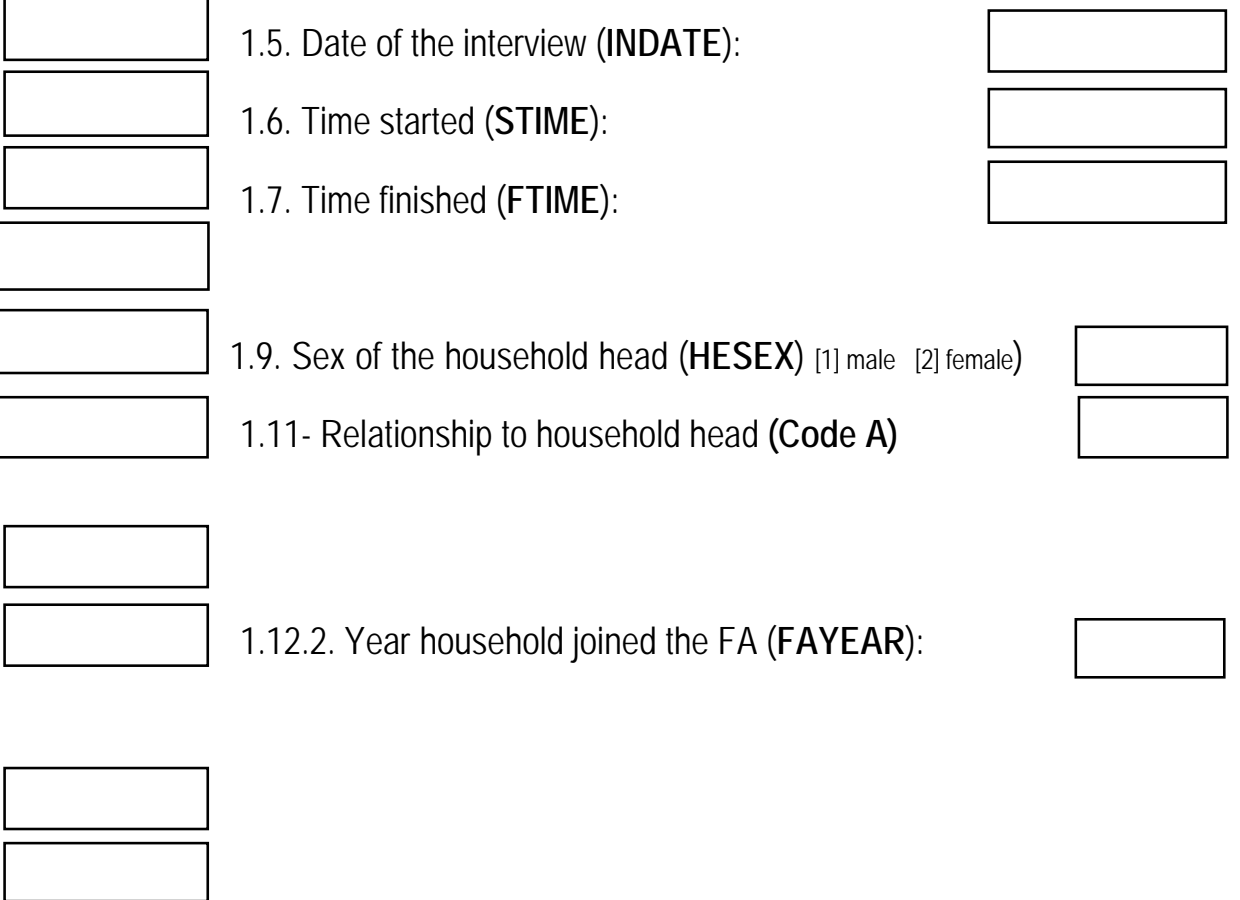

1.15. Land phone number:

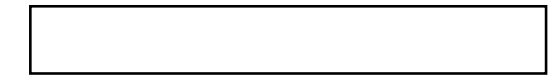


MODULE 2. DEMOGRAPHICS OF THE HOUSEHOLD

DEMOS

2.1. Please fill information of all members of the household (please start with the head of the household)

\begin{tabular}{|c|c|c|c|c|c|c|c|c|c|c|}
\hline 1 & 2 & 3 & 4 & 5 & 6 & 7 & 8 & 9 & 10 & 11 \\
\hline 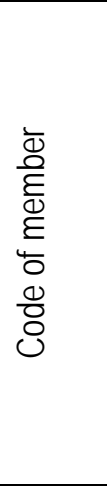 & $\begin{array}{c}\text { Full name of } \\
\text { household } \\
\text { member }\end{array}$ & $\begin{array}{c}\text { Sex } \\
\\
\text { [1] male } \\
\text { [2] female }\end{array}$ & $\begin{array}{c}\text { Age } \\
\text { (in years } \\
\text { completed) }\end{array}$ & $\begin{array}{l}\text { What is [name] } \\
\text { relationship to the } \\
\text { household head? } \\
\text { Code A [1] Head } \\
\text { [2] Wife/Husband } \\
\text { [3] Son/Daughter } \\
\text { [4] Son/Daughter in law } \\
\text { [5] Father/Mother } \\
\text { [6] Father/Mother in law } \\
\text { [7] Sister/Brother } \\
\text { [8] Grandchild } \\
\text { [9] Other relatives } \\
\text { [10] No answer } \\
\text { [99] Not applicable }\end{array}$ & $\begin{array}{l}\text { [Only persons } \\
\quad \text { aged } \geqslant 18 \text { ] } \\
\text { Marital status } \\
\text { [1] Not married } \\
\text { [2] Married } \\
\text { [3] Widow } \\
\text { [4] Divorced } \\
\text { [5] Separated } \\
\text { [10] No answer } \\
\text { [99] Not applicable }\end{array}$ & $\begin{array}{c}\text { [Only persons aged } \\
\qquad \geqslant 6] \\
\text { What is the highest } \\
\text { level of education of } \\
\text { [member]? } \\
\text { [Code B] }\end{array}$ & $\begin{array}{c}\text { What is } \\
\text { main } \\
\text { occupation } \\
\text { of } \\
\text { [member]? } \\
\text { [Code } \mathrm{C} \text { ] }\end{array}$ & $\begin{array}{c}\text { Does the } \\
\text { [member] } \\
\text { contribute to } \\
\text { farm work? } \\
\\
\text { [1] Yes } \\
\text { [2] No }\end{array}$ & $\begin{array}{l}\text { Does the } \\
\text { [member] } \\
\text { work non- } \\
\text { farm? } \\
\\
\text { [1] Yes } \\
\text { [2] No }\end{array}$ & $\begin{array}{c}\text { Does } \\
\text { [member] of } \\
\text { household } \\
\text { belong to any } \\
\text { social- } \\
\text { political } \\
\text { organization? } \\
\text { [1] Yes } \\
\text { [2] No }\end{array}$ \\
\hline MBID & FULNAME & GEN & AGE & RELATION & MARIED & EDULEVEL & JOB & CONTRI & OFFHHMB & ORGHHMB \\
\hline 01 & & & & 1=head & & & & & & \\
\hline 02 & & & & & & & & & & \\
\hline 03 & & & & & & & & & & \\
\hline 04 & & & & & & & & & & \\
\hline 05 & & & & & & & & & & \\
\hline 06 & & & & & & & & & & \\
\hline 07 & & & & & & & & & & \\
\hline 08 & & & & & & & & & & \\
\hline 09 & & & & & & & & & & \\
\hline 10 & & & & & & & & & & \\
\hline 11 & & & & & & & & & & \\
\hline 12 & & & & & & & & & & \\
\hline Code B: & [1] illiteracy [2] Prim & & Secondary & [4] High scho & [5] College & [6] Othe & cify) & swer & t applicable & \\
\hline Code C: & [1] Farmer [2] Loca & & Wage labor & [4] Teacher & etired & [7] Stud & [8] & loyed & r (specify) & \\
\hline
\end{tabular}




\section{MODULE 3. TENURE AND FARM PRODUCTION}

3.1. What is the total amount of land that the household currently own? (TOAREA)

3.2. What is the total amount of land that the household owned 5 years ago? (TOAREA5Y)

3.3. What is the total amount of land cultivated by the household? (CULTAREA)

3.4. Number of plots (NPLOT):

Please fill the characteristics of each plot in the table below. Please start with the plots were used for planting specialty rice first, then other rice varieties

\begin{tabular}{|c|c|c|c|c|c|c|c|c|c|c|}
\hline 1 & \multicolumn{2}{|c|}{2} & \multirow{4}{*}{$\begin{array}{l}\frac{1}{1} 3 \\
\text { Type of plant } \\
\text { in the plot: } \\
\text { [1] } 2 \text { rice } \\
\text { [2] } 2 \text { rice and winter } \\
\text { crop } \\
\text { [3] Other (specify) }\end{array}$} & \multirow{4}{*}{\begin{tabular}{l}
\multicolumn{1}{c}{4} \\
Soil quality \\
[1] High fertility \\
[2] Neutral \\
[3] Poor fertility \\
[4] Other (specify)
\end{tabular}} & \multirow{4}{*}{$\begin{array}{c}5 \\
\text { How far is } \\
\text { from } \\
\text { homestead to } \\
\text { the plot? } \\
(\mathrm{km})\end{array}$} & \multirow{4}{*}{$\begin{array}{c}6 \\
\text { Is this plot is } \\
\text { irrigated? }\end{array}$} & \multirow{4}{*}{\begin{tabular}{l}
\multicolumn{1}{c}{7} \\
How did you obtain \\
$\quad$ this plot? \\
[1] Was divided officially \\
[2] Inheritance or gift \\
[3] Buying \\
[4] Renting in \\
[5] Borrowing in \\
[6] Other (specify)
\end{tabular}} & \multirow{4}{*}{$\begin{array}{c}8 \\
\text { Do you have any } \\
\text { certificate of land } \\
\text { use for this plot? } \\
\\
\text { [1] Yes } \\
\text { [2] No }\end{array}$} & \multirow{3}{*}{\multicolumn{2}{|c|}{$\begin{array}{l}9 \\
\text { If the plot was rented in, how } \\
\text { much would you pay now } \\
\text { per unit? }\end{array}$}} \\
\hline \multirow{4}{*}{$\begin{array}{l}5 \\
\text { 오 } \\
0 \\
\end{array}$} & \multicolumn{2}{|c|}{ Land area } & & & & & & & & \\
\hline & \multirow{2}{*}{\multicolumn{2}{|c|}{$\begin{array}{c}\text { What is the area of the } \\
\text { plot? }\end{array}$}} & & & & & & & & \\
\hline & & & & & & & & & \begin{tabular}{l}
\multicolumn{1}{c}{ Unit } \\
[1] Per month \\
[2] Per 6 month \\
[3] Per year
\end{tabular} & $\begin{array}{l}\text { How much } \\
\text { 1000VND }\end{array}$ \\
\hline & LANDAREA & LANDUNIT & LANDPRO & LANDFER & LANDFAR & LANDWATER & HOWGET & LANDCER & UNIPAY & RENTPAY \\
\hline \multicolumn{11}{|l|}{1} \\
\hline \multicolumn{11}{|l|}{2} \\
\hline \multicolumn{11}{|l|}{3} \\
\hline \multicolumn{11}{|l|}{4} \\
\hline \multicolumn{11}{|l|}{5} \\
\hline \multicolumn{11}{|l|}{6} \\
\hline \multicolumn{11}{|l|}{7} \\
\hline \multicolumn{11}{|l|}{8} \\
\hline \multicolumn{11}{|l|}{9} \\
\hline \multicolumn{11}{|l|}{10} \\
\hline \multicolumn{11}{|l|}{11} \\
\hline \multicolumn{11}{|l|}{12} \\
\hline \multicolumn{11}{|c|}{13} \\
\hline 14 & & & & & & & & & & \\
\hline
\end{tabular}

$\begin{array}{llll}\text { Amount } & & \text { Unit: } & \\ \text { Amount } & \text { Unit: } & \\ \text { Amount } & \text { Unit: } & \\ & & \end{array}$

Amoun

Unit: [1] Sao (local unit, equivalent 360m2) ; [2] m2 
3.5. Rice production and marketing

3.5.1. How many years have you been planting rice in general? (EXPERICE)

(hat produced rice during the last 12 months (July 2013 - June 2014), starting with the plot (parcel) planted specialty rice varieties

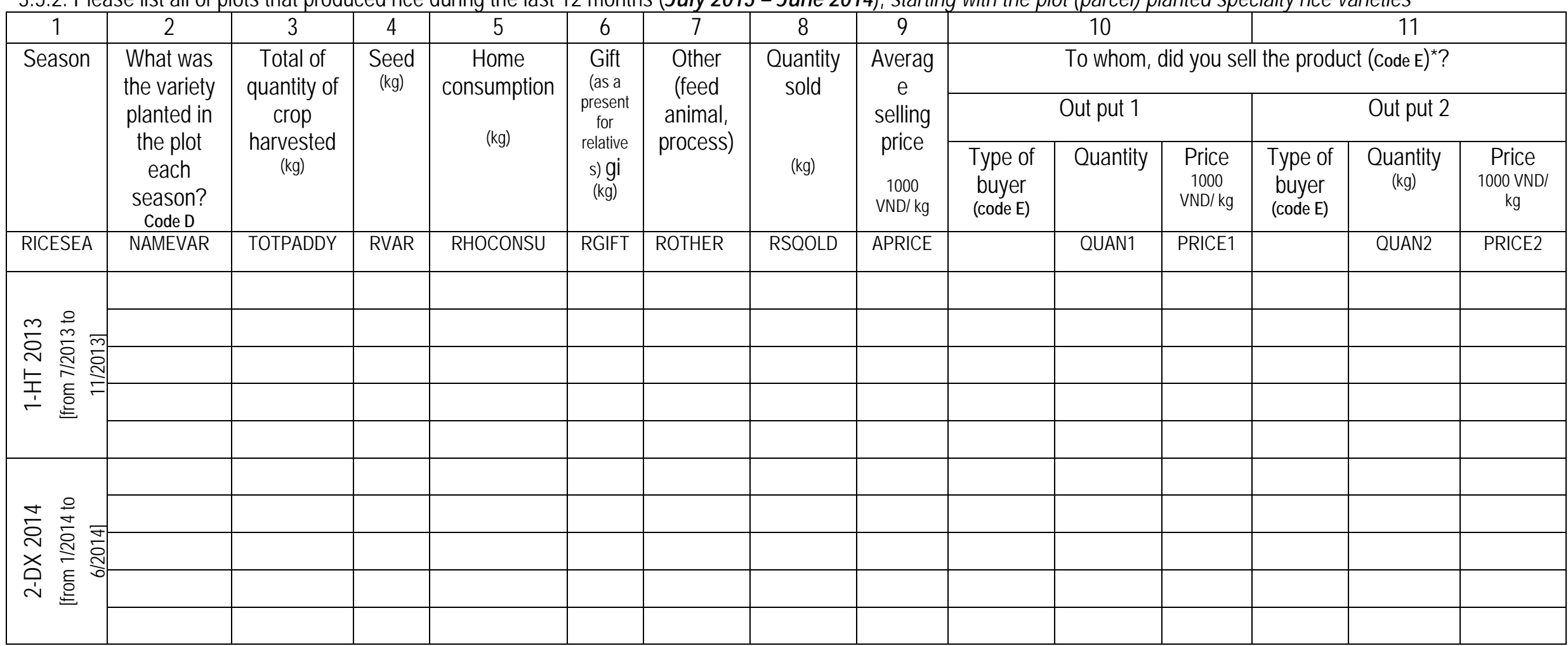

Code D: [1] Hoa Vang stiky rice

Code E: [1] FAs

[2] Aromatic rice

[3] BCR; [4] 415 sticky rice;

[5] Other rice;

[10] No answer;

[99] Not applicable;

Only for household planted specialty rice:

3.5.3. After harvesting, did you sell the specialty paddy immediately (KEEPRICE)? [1] Yes; [2] No

3.5.4. How long did you keep specialty paddy in stock before selling(KEEPLONG)? Number of months

3.5.5. Production cost per one sao (1 sao = $360 \mathrm{~m} 2)$; (First starting specialty rice, then ordinary rice)
ALLRICE
[99] Not applicable

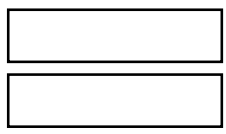


Questionnaires

\begin{tabular}{|c|c|c|c|c|c|c|c|c|c|c|c|c|}
\hline \multirow[b]{3}{*}{ Items } & \multicolumn{6}{|c|}{ 1-Rice season 2013(From 7/2013 to 11/2013) } & \multicolumn{6}{|c|}{ 2-Rice season 2014(From 1/2014 to 7/2014) } \\
\hline & \multicolumn{3}{|c|}{ Type (code D) } & \multicolumn{3}{|c|}{ Type (code D) .......... } & \multicolumn{3}{|c|}{ Type (code D) .......... } & \multicolumn{3}{|c|}{ Type (code D) ........... } \\
\hline & Quantity & $\begin{array}{c}\text { Price } \\
\text { 1000VND/ } \\
\text { unit }\end{array}$ & $\begin{array}{l}\text { Amount } \\
\text { (1000 VND) }\end{array}$ & $\begin{array}{c}\text { Quantit } \\
y\end{array}$ & $\begin{array}{c}\text { Price } \\
\text { 1000VND/unit }\end{array}$ & $\begin{array}{c}\text { Amount } \\
(1000 \\
\text { VND) }\end{array}$ & Quantity & $\begin{array}{c}\text { Price } \\
\text { 1000VND/unit }\end{array}$ & $\begin{array}{l}\text { Amount } \\
\text { (1000 VND) }\end{array}$ & Quantity & $\begin{array}{c}\text { Price } \\
\text { 1000VND/unit }\end{array}$ & $\begin{array}{l}\text { Amount } \\
\text { (1000 VND) }\end{array}$ \\
\hline 1. Seed (SEED) (kg) & & & & & & & & & & & & \\
\hline Source (code F) & & & & & & & & & & & & \\
\hline 2. Landing preparation & & & & & & & & & & & & \\
\hline 3. Fertilizer & & & & & & & & & & & & \\
\hline 3.1. Manure (PC) & & & & & & & & & & & & \\
\hline 3.2. N2O5 (N2) & & & & & & & & & & & & \\
\hline 3.2. P2O5 (P2O5) & & & & & & & & & & & & \\
\hline 3.3. Kali (KALI) & & & & & & & & & & & & \\
\hline 3.4. NPK (mixed fertilizer) & & & & & & & & & & & & \\
\hline 3.5. Other (specify) & & & & & & & & & & & & \\
\hline 4. Pesticide (PEST) & & & & & & & & & & & & \\
\hline 5. Herbicide (HERB) & & & & & & & & & & & & \\
\hline 6. Labor (LABOR) & & & & & & & & & & & & \\
\hline + Hired labor (No.) & & & & & & & & & & & & \\
\hline + Family labor (No.) & & & & & & & & & & & & \\
\hline 7. Threshing & & & & & & & & & & & & \\
\hline $\begin{array}{l}\text { 8. Packaging, keeping and } \\
\text { label }\end{array}$ & & & & & & & & & & & & \\
\hline $\begin{array}{l}\text { 9. Other (water supply, safe } \\
\text { guard) }\end{array}$ & & & & & & & & & & & & \\
\hline $\begin{array}{l}\text { Code D: [1] Hoa Vang stiky rice } \\
\text { Code F: [1] last year seed; }\end{array}$ & $\begin{array}{l}\text { ] Aromatic rice; } \\
\text { ] FAs; }\end{array}$ & $\begin{array}{r}{[3] \mathrm{BCR} \text {; }} \\
\text { perative and }\end{array}$ & $\begin{array}{l}\text { [4] } 415 \text { sticky } \\
\text { ricultural depar }\end{array}$ & $\begin{array}{l}\text { ice; } \\
\text { ment }\end{array}$ & $\begin{array}{l}\text { ther rice; } \\
\text { eighbors; }\end{array}$ & $\begin{array}{l}\text { [10] No answ } \\
\text { [5] Relatives; }\end{array}$ & & $\begin{array}{l}\text { tapplicable; } \\
\text { er (specify); }\end{array}$ & ]] No answer; & 9] o & olicable; & \\
\hline
\end{tabular}


3.6. Please give the following production and revenue details for the crops grown during the last 12 months [July 2013 to June 2014]

Apart from rice production, did you plant any kind of crops during the past 12 months? [1] Yes [2] No, go to 3.7

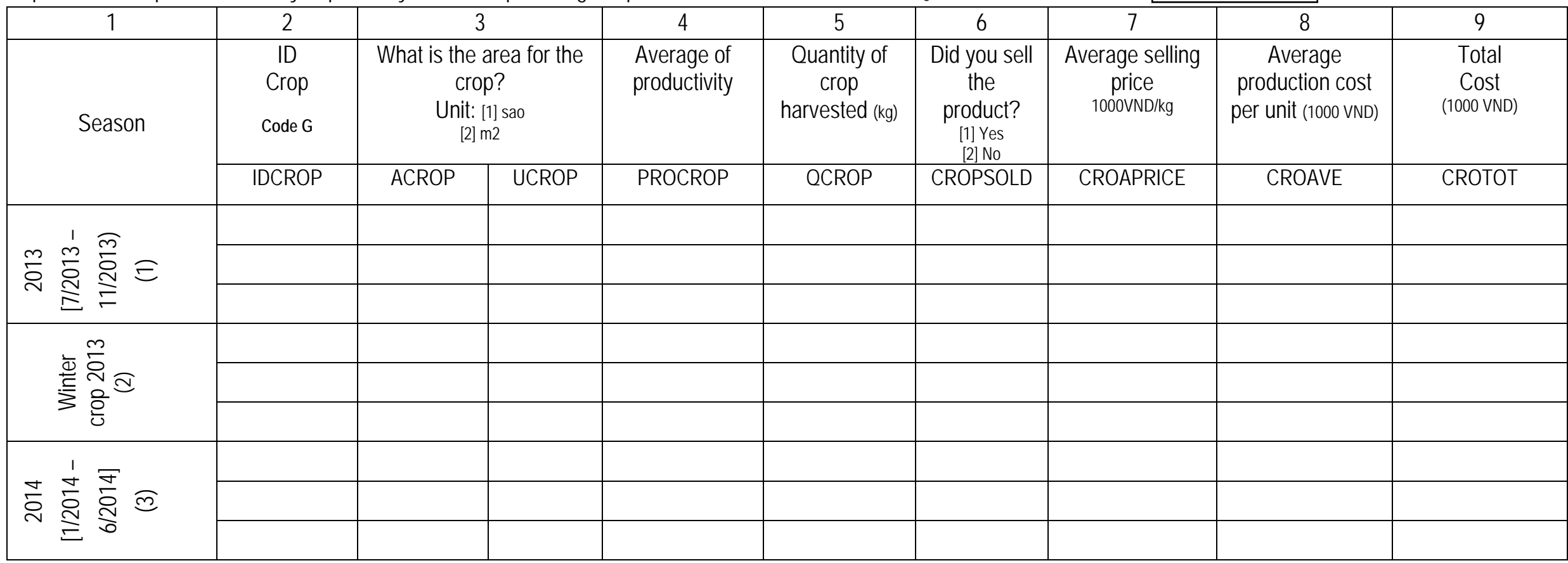

Code G: [1] Onion; [2] Garlic; [3] Vegetables; [4] Kudzu; [5] Watermelon; [6] Peanut; [7] Other (specify..........................)

(* Note: If farmers do not remember the individuals of production costs, try to ask them total amount of money that they had paid for the crop) 
3.7. Livestock

Did you keep any of livestock during the past 12 month (July 2013 to June 2014)?

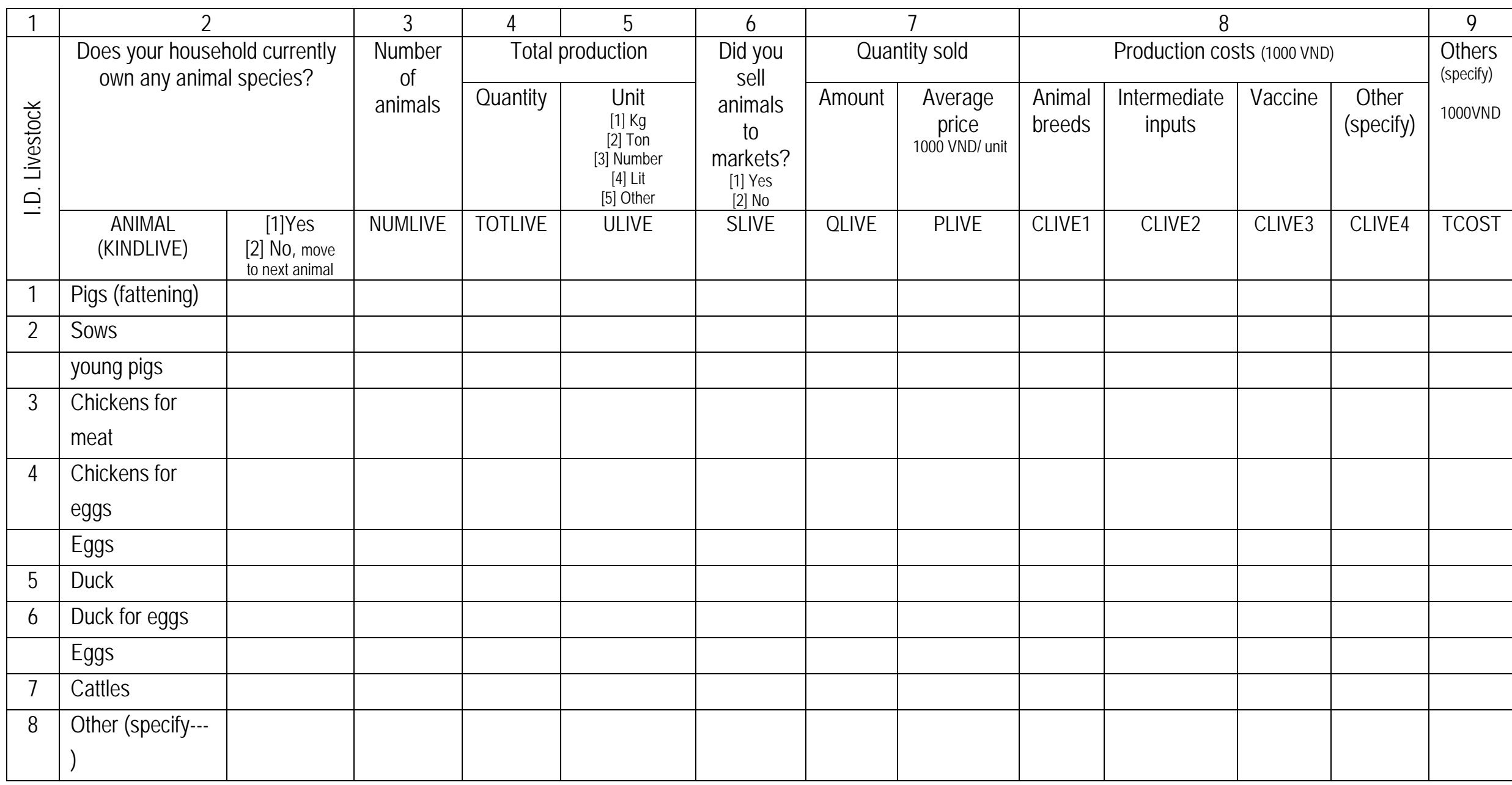

(* Note: If farmers do not remember the individuals of production costs, try to ask them total amount of money that they had paid for the crop) 


\section{MODULE 4. HOUSEHOLD ASSETS}

ASSET

Does your household own any the following items? (Please list of all items that the household owned currently)

\begin{tabular}{|c|c|c|c|c|c|c|c|c|c|}
\hline 1 & 2 & 3 & 4 & 5 & 1 & 2 & 3 & 4 & 5 \\
\hline 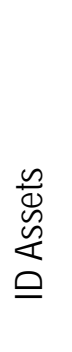 & Item & $\begin{array}{l}\text { How many items } \\
\text { do your household } \\
\text { own currently? } \\
\text { [1] If none, record } 0 \text { and } \\
\text { skip to the next item }\end{array}$ & $\begin{array}{c}\text { Which year did } \\
\text { you acquire this } \\
\text { [Item]? } \\
\text { (year) }\end{array}$ & $\begin{array}{c}\text { If you } \\
\text { wanted to } \\
\text { sell [item] } \\
\text { today, how } \\
\text { much would } \\
\text { you receive? } \\
1000 \text { VND }\end{array}$ & 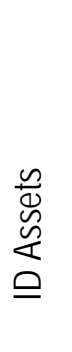 & Item & $\begin{array}{l}\text { How many items } \\
\text { does your } \\
\text { household own } \\
\text { currently? } \\
\text { [1] If none, record } 0 \text { and } \\
\text { skip to the next item }\end{array}$ & $\begin{array}{l}\text { Which year } \\
\text { did you } \\
\text { acquire this } \\
\text { [Item]? } \\
\text { (year) }\end{array}$ & $\begin{array}{c}\text { If you wanted to } \\
\text { sell [item] today, } \\
\text { how much would } \\
\text { you receive? } \\
1000 \text { VND }\end{array}$ \\
\hline IDA & TYPEASS & NUMASS & WHENASS & SELLASS & IDA & TYPEASS & NUMASS & WHENASS & SELLASS \\
\hline 1 & Motorcycle (s) & & & & 9 & Tractor 2 wheel (s) & & & \\
\hline 2 & Bicycle (s) & & & & 10 & Tractor 4 wheel (s) & & & \\
\hline 3 & TV (s) & & & & 11 & Water pump & & & \\
\hline 4 & Radio (s) & & & & 12 & Harvesting machine & & & \\
\hline 5 & Land phone (s) & & & & 13 & Storage facilities & & & \\
\hline 6 & Mobile phone (s) & & & & 14 & Generator & & & \\
\hline 7 & Computer (s) & & & & 15 & Pigsty, stable & & & \\
\hline 8 & Knapsack sprayer (s) & & & & 16 & Other (specify) & & & \\
\hline
\end{tabular}

(Notice: If respondents could not remember when they bought the asset or the value of asset, write code 99) 
MODULE 5. NON-FARM INCOME (Non-farm activities are all activities not related to agricultural production on your own farm).

OFFARM

5.1. Have any of household members been engaged in non-farm activities during the past 12 months? [1] Yes

[2] No, move to section 5.3

5.2. Please list all of these activities during the past 12 months

(if one member is engaged in more than one activity, use more than one row)

\begin{tabular}{|c|c|c|c|}
\hline 1 & 2 & 3 & 4 \\
\hline \begin{tabular}{l}
\multicolumn{1}{c}{ MBID [member] } \\
$\quad$ Code A \\
[Member participated in any \\
non-farm activities or had an \\
income outside farm activities)
\end{tabular} & $\begin{array}{l}1 \text { Sales } \\
2 \text { Services } \\
3 \text { Wage labor } \\
4 \text { Retired salary and allowance of non-farm income } \\
5 \text { Remittance } \\
6 \text { Subsidies } \\
7 \text { Other (specify) } \\
10 \text { No answer } \\
99 \text { Not applicable }\end{array}$ & $\begin{array}{c}\text { How many months did } \\
\text { [member] work a year on } \\
\text { average? } \\
1000 \mathrm{VND}\end{array}$ & $\begin{array}{c}\text { How much did [member] get per month } \\
\text { on average? } \\
1000 \mathrm{VND}\end{array}$ \\
\hline MBID & NONFJOB & MONCOM & MONWORK \\
\hline & & & \\
\hline & & & \\
\hline & & & \\
\hline & & & \\
\hline & & & \\
\hline & & & \\
\hline
\end{tabular}

Code A: [1] Head; [2] Wife/Husband; [3] Son/Daughter; [4] Son/Daughter in law; [5] Father/Mother; [6] Father/Mother in law; [7] Sister/Brother; [8] Grandchild; [9] Other relatives; [10] No answer; [99] Not applicable

5.3. What is the average daily wage rate in the village in general currently? normal $1000 \mathrm{VND} /$ day.

1000VND/day; harvesting season:

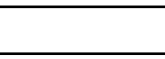




\section{MODULE 6. SPECIALTY RICE PRODUCTION AND MARKETING}

6.1. Have you ever planted specialty rice? [1] Yes; [2] № (please go to module 7)

6.1.1. When did you start to plant specialty rice? (EXPESRICE)

6.1.2. Have you ever heard that the specialty rice in your region is protected collective mark? [1] Yes; [2] No

6.2. Why did your household choose to plant specialty rice?

\begin{tabular}{|l|l|}
\hline \multicolumn{1}{|c|}{ Reason for choosing planting specialty rice varieties } & \multicolumn{2}{|l}{ Answer } \\
\hline * Improve household income (IMPROVE) & \\
\hline It can be sold with a higher price than normal ones & \\
\hline It helps to save production costs & {$[3]$ I don't know } \\
\hline It has a stable productivity & \\
\hline It is easy to sell the product & \\
\hline * Specialty rice and its impacts on social aspect of region (SOCIAL) & \\
\hline It contributes to region traditional culture & \\
\hline Its production is safe to environment by reducing amount of fertilizer and pesticide & \\
\hline * It is suitable to regional development strategies (REGIONAL) & \\
\hline In planned area for specialty rice & \\
\hline Gain knowledge through involved in training and extension activities &
\end{tabular}

6.3. Since 2010, how much cultivated area and crop harvested of the specialty rice have you been growing?

\begin{tabular}{|c|c|c|c|c|c|c|c|c|c|c|c|c|}
\hline \multicolumn{3}{|c|}{2010} & \multicolumn{3}{|c|}{2011} & \multicolumn{3}{|c|}{2012} & 2013 & \multicolumn{3}{|c|}{ Current year (2014) } \\
\hline Area & $\begin{array}{l}\text { Unit } \\
\text { [1] sao; } \\
\text { [2] m2 }\end{array}$ & $\begin{array}{c}\text { Harvested } \\
\text { quantity } \\
\mathrm{kg}\end{array}$ & Area & $\begin{array}{l}\text { Unit } \\
{[1] \text { sao; }} \\
{[2] \mathrm{m} 2}\end{array}$ & $\begin{array}{c}\text { Harvested } \\
\text { quantity } \\
\mathrm{kg}\end{array}$ & Area & $\begin{array}{l}\text { Unit } \\
\text { [1] sao; } \\
\text { [2] m2 }\end{array}$ & $\begin{array}{c}\text { Harvested } \\
\text { quantity } \\
\mathrm{kg}\end{array}$ & Area & Area & $\begin{array}{l}\text { Unit } \\
\text { [1] sao; } \\
\text { [2] m2 }\end{array}$ & $\begin{array}{c}\text { Harvested } \\
\text { quantity } \\
\mathrm{kg}\end{array}$ \\
\hline ASRICE10 & USRICE10 & QSRICE10 & ASRICE11 & USRICE11 & QSRICE11 & ASRICE12 & USRICE12 & QSRICE12 & ASRICE14 & ASRICE14 & USRICE14 & QSRICE14 \\
\hline
\end{tabular}

On average, the productivity of specialty rice in the period of 3 year (2010-2012)

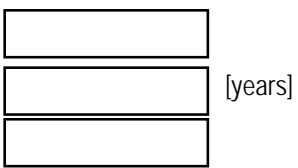

$\mathrm{kg} / \mathrm{sao}(1 \mathrm{sao}=360 \mathrm{~m} 2)$ 
6.4. Which source did you get the information about price and market of specialty rice?

[1] Neighbor; [2] Extension agent; [3] TV or radio; [4] Internet; [5] Researcher; [6] Trader; [7] Other (specify); [10] No answer; [99] Not applicable

\begin{tabular}{|c|c|c|c|}
\hline \multirow{2}{*}{ Source } & \multicolumn{3}{|c|}{ Source of information } \\
\hline & SOURCE1... & SOURCE2... & SOURCE3... \\
\hline $\begin{array}{l}\text { 6.4.1. How many times did you exchange market - related information with each source in the } \\
\text { months? [1] Once; [2] Twice; [3] Three times; [4] Others (specify------o---) }\end{array}$ & & & \\
\hline $\begin{array}{l}\text { 6.4.2. How would you estimate the importance of marker-related information of each source? } \\
\text { [1] Very unimportant; [2] Slightly unimportant; [3] Neither important nor unimportant; [4] Slightly important; [5] Very important }\end{array}$ & & & \\
\hline
\end{tabular}

6.5. Have you ever sold specialty rice to FA for the last five years? [1] Yes; [2] No, move to 6.6

6.5.1. Why did you choose to sell your product to FA? (list three most important reason)

[1] Trust FAs; [2] Reputation; [3] Easy distribution

[4] Following the agreement; [5] Other (specify); [10] No answer; [99] No applicable

6.5.2. Did you get money after selling the products to FA (PAYMENT)? [1] Yes; [2] No, move to 6.6

How long did you wait for getting the money? Number of days

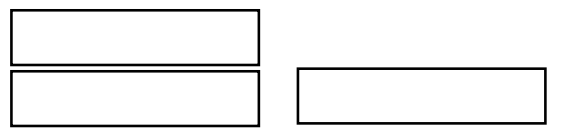

6.6. Did you sort specialty rice by quality after harvesting or before selling? [1] Yes; [2] No, move to module 7

6.7. How many aspects did you sort by (list the 3 most important aspects)?

$\begin{array}{llll}\text { [1] Humidity [2] Fragrantfflavored [3] Shape } & \text { [4] Uniformity }\end{array}$
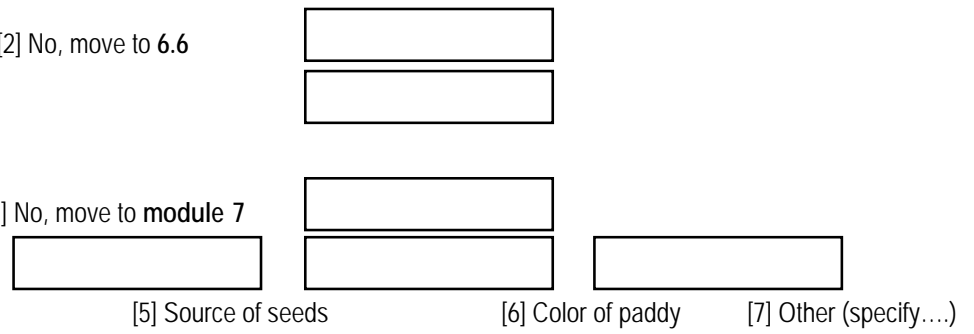
MODULE 7. THE ROLE OF FARMER ASSOCIATION (This section is not applied for who have not participated in farmer association)

7.1. How is your satisfaction to cooperate with FAs

\begin{tabular}{|c|c|c|}
\hline Do you agree with these statements below? & (SATIS) & $\begin{array}{c}\text { Answer } \\
\text { [1] Yes; [2] No; [3] I don't know }\end{array}$ \\
\hline \multicolumn{3}{|l|}{ Use good seeds provided by FA } \\
\hline \multicolumn{3}{|l|}{ Improve technical skills in specialty rice production } \\
\hline \multicolumn{3}{|l|}{ Got advice from FA leaders in production processes } \\
\hline \multicolumn{3}{|l|}{ Productivity has increased after joining FA } \\
\hline \multicolumn{3}{|l|}{ Improve the quality of product, } \\
\hline \multicolumn{3}{|l|}{ Get subsidies (money, fertilizers, pesticides) from NGOs or donors } \\
\hline Receiving a higher selling price than other chain actors at the same time & & \\
\hline
\end{tabular}

7.2. Willing to contribute to FA objectives

7.2. Willing to contribute to FA objectives
\begin{tabular}{|l|l|}
\hline \multicolumn{1}{|c|}{ Do you agree with these statements below? } & Answer \\
\hline $\begin{array}{l}\text { If FA does not directly benefit you, but has benefits for other members of organization, you would contribute labor and } \\
\text { money to the FA. }\end{array}$ & \\
\hline If FA has struggles with debt, you will contribute money to solve problems. & \\
\hline $\begin{array}{l}\text { If FA has struggles with marketing strategy and delaying payment for your product, you would wait until the problem } \\
\text { solved. }\end{array}$ & \\
\hline
\end{tabular}

7.3. Trust farmer association

7.3. Trust farmer association
\begin{tabular}{|l|c|}
\hline Do you agree with these statements below? & Answer \\
\hline FA always treat me fairly & {$[1]$ Yes; [2] No; [3] I don't know } \\
\hline In general, I am skeptical of the information I received from my FA & \\
\hline
\end{tabular}

7.2. Besides participating to $F A$, does any member of household involved in any organization:
[1] Agricultural cooperatives
[2] Vietnam farmer's union
[3] Vietnam women's union
[4] Youth union
[5] Elderly association
[6] Veteran association
[7] Other (specify)

\begin{tabular}{|c|c|c|c|c|c|}
\hline ORG1 & ORG2 & ORG3 & ORG4 & ORG5 & ORG6 \\
\hline & & & & & \\
\hline
\end{tabular}




\section{MODULE 8. CREDIT}

During the past 12 months, has any member of your household borrowed any cash or goods?

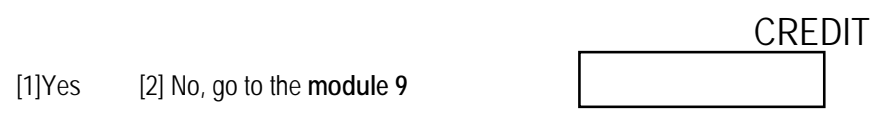

\begin{tabular}{|c|c|c|c|c|c|c|}
\hline 1 & 2 & 3 & 4 & & 5 & 6 \\
\hline \multirow{2}{*}{$\begin{array}{l}\text { LOAN CODE } \\
\text { [1] Cash } \\
\text { [2] Goods } \\
\text { [3] Gold } \\
\text { [4] Other (specify) }\end{array}$} & \multirow{2}{*}{$\begin{array}{c}\text { What was the } \\
\text { amount of } \\
\text { loan HH } \\
\text { applied? } \\
\text { 1000 VND }\end{array}$} & \multirow{2}{*}{$\begin{array}{c}\text { What was the amount of } \\
\text { loan } \mathrm{HH} \text { member } \\
\text { received? } \\
1000 \mathrm{VND}\end{array}$} & \multirow{2}{*}{$\begin{array}{l}\text { Where did you borrow the loans? } \\
\text { [1] AGRIBANK; [2] Neighbor } \\
\text { [3] Wholesales; [4] Other official finance } \\
\text { [5]Non-financial institution } \\
\text { [6] Friends/relatives; [7] Other (specify) } \\
\text { [10] No answer } \\
\text { [99] Not applicable }\end{array}$} & \multicolumn{2}{|c|}{$\begin{array}{l}\text { How long did you wait for } \\
\text { the loan? }\end{array}$} & \multirow{2}{*}{$\begin{array}{l}\text { What was the main reason for borrowing } \\
\text { this loan? } \\
\text { [1] Agricultural investment } \\
\text { [2] Non-farm investment } \\
\text { [3] Education; [4] Health; [5] Other (specify) } \\
\text { [10] No answer; [99]Not applicable }\end{array}$} \\
\hline & & & & Amount & $\begin{array}{c}\text { Unit } \\
1 \text { Days } \\
2 \text { Months } \\
3 \text { Other (specify) }\end{array}$ & \\
\hline LOANCODE & AMOLOAN & RECLOAN & WHELOAN & TIMELOAN & LOANUNIT & LOANPUR \\
\hline & & & & & & \\
\hline & & & & & & \\
\hline & & & & & & \\
\hline
\end{tabular}

\section{MODULE 9. EXTENSION AND TRAINING}

9.1. Did anyone in this household receive extension advice from any source during the last 12 months? [1] Yes 9.2. Where did member in your family get information from (EXTEN)?

\begin{tabular}{|c|c|c|c|c|c|c|c|}
\hline \multirow[t]{2}{*}{ Code source } & \multirow{2}{*}{$\begin{array}{l}\text { Did you get } \\
\text { information in the } \\
\text { last year? } \\
\text { [1] Yes } \\
\text { [2] No, go to next source }\end{array}$} & \multicolumn{2}{|c|}{$\begin{array}{c}\text { How often you get extension } \\
\text { advice? } \\
\text { Unit: [1] Week [2] Month [3] Year }\end{array}$} & \multirow{2}{*}{\multicolumn{3}{|c|}{$\begin{array}{c}\text { What kind of information you get? } \\
1 \text { Specialty rice production; } \\
2 \text { Other crops production; } 3 \text { Livestock production; } \\
4 \text { collective actions; } 5 \text { input source; } \\
6 \text { Market information; } 7 \text { Weather; } 8 \text { Credit and finance; } \\
9 \text { Other (specify------) }\end{array}$}} & \multirow{3}{*}{$\begin{array}{l}\text { How helpful the information you } \\
\quad \text { had in the last year? } \\
\text { [1] Very unhelpful; [2] Slightly unhelpful; [3] } \\
\text { Neither helpful nor unhelpful; } \\
\text { [4] Slightly helpful; [5] Very helpful } \\
\text { HELPINFO }\end{array}$} \\
\hline & & Amount & Unit & & & & \\
\hline CODEEXT & EXTINFO & EXFQ & UNIEXT & EX1 & EX2 & EX3 & \\
\hline \multicolumn{8}{|l|}{ (1)Extension officers } \\
\hline \multicolumn{8}{|c|}{ (2)Company (fertilizer or pesticide) } \\
\hline \multicolumn{8}{|l|}{$\begin{array}{l}\text { (3) Executive committee of } \\
\text { association }\end{array}$} \\
\hline \multicolumn{8}{|l|}{ (4)Agricultural department } \\
\hline \multicolumn{8}{|l|}{ (5)Agricultural cooperative } \\
\hline (6)Other (specify) & & & & & & & \\
\hline
\end{tabular}

\section{EXTEN}

[2] No, go to the module 10

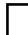




\section{MODULE 10. SHOCKS}

10.1. Were there any shocks having negative impact on household income the last 12 months?

\begin{tabular}{|l|l|l|l|}
\hline \multicolumn{1}{|c|}{ SHOCKS } & $\begin{array}{c}\text { Was it } \\
\text { happen? } \\
\text { 1 Yes } \\
2 \text { No, go to the } \\
\text { next shock } \\
\text { frequently } \\
\text { was shock } \\
\text { happen? } \\
\text { Code } \mathbf{H}\end{array}$ & $\begin{array}{c}\text { How was the } \\
\text { household } \\
\text { affected by } \\
\text { [shock]? } \\
\text { Code I }\end{array}$ \\
\hline [1]Too much rain & & & \\
\hline [2] The higher temperature & & & \\
\hline [3] Flooding & & & \\
\hline [4] Insect disease & & & \\
\hline [5] Storm & & & \\
\hline [6] Serious illness of household \\
member
\end{tabular}

Code H: [1] Never; [2] 1-3 times; [3] 4-6; Greater than 6; Code I: [1] Not at all; [2] Slightly; [3] Considerably [4]Very severely; 10.2. Recovery from these shocks (Please ask the respondent to answer these items below)

\begin{tabular}{|l|l|l|l|}
\multicolumn{1}{|c|}{ SHOCKS } & $\begin{array}{c}\text { Was it } \\
\text { happen? } \\
\text { 1 Yes } \\
\text { 2 No, go to the } \\
\text { next shock }\end{array}$ & $\begin{array}{c}\text { How } \\
\text { frequently } \\
\text { was shock } \\
\text { happen? } \\
\text { Code H }\end{array}$ & $\begin{array}{c}\text { How was the } \\
\text { household } \\
\text { affected by } \\
\text { [shock]? } \\
\text { Code I }\end{array}$ \\
\hline $\begin{array}{l}\text { [7] Strong increase of prices for } \\
\text { inputs }\end{array}$ & & & \\
\hline $\begin{array}{l}\text { [8] Strong decrease of prices for } \\
\text { outputs }\end{array}$ & & & \\
\hline [9] Theft of crops or livestock & & & \\
\hline [10] Fire & & & \\
\hline [11] Death of relatives & & & \\
\hline [12] Other (specify----------) & & & \\
\hline
\end{tabular}

\begin{tabular}{|l|l|}
\multicolumn{1}{|c|}{ Items } & $\begin{array}{c}\text { What did you do to recover from } \\
\text { these shocks? [1] Yes; [2] No }\end{array}$ \\
\hline [1] Diversify agricultural varieties & \\
\hline [2] Reduced production inputs & \\
\hline [3] Adult migrated to look for job & \\
\hline [4] Sold livestock (pig, cow) & \\
\hline [5] Sold crop products (maize, rice) & \\
\hline [6] Sold assets (TV, machinery) & \\
\hline
\end{tabular}

\begin{tabular}{|l|l|}
\multicolumn{1}{|c|}{ Items } & $\begin{array}{c}\text { What did you do to recover from } \\
\text { these shocks? [1] Yes; [2] No }\end{array}$ \\
\hline [7] Borrowed from relatives/friends/neighbors & \\
\hline [8] Borrowed from bank/financial funds & \\
\hline [9] Supported from local government & \\
\hline [10] Help from NGOs & \\
\hline [11]Help from relatives/friends/neighbors & \\
\hline [12]Other (specify------------) & \\
\hline
\end{tabular}


11.1. About how many close farmers do you have these days in the village? Those are people you feel at ease with, can talk to about private matters, or call on for help?

11.2. If you suddenly needed a given amount of money (that is enough to pay for expenses for your household for one week), how many people beyond your immediate household could you turn to who would be willing to provide this money: [1] № one; [2] One or two people; [3] Three or four people; [4] Five or more people

11.3. [If not zero] of those people, how many do you think are currently able to provide this money?

11.4. [If not zero] Are most of these people of similar/higher/lower economic status? [1] Similar; [2] Higher; [3] Lower

11.5. If you suddenly had to go away for a day or two, could you count on your neighbors to take care of your children/grand children?

11.6. If you suddenly faced a long-term emergency such as harvest failure, how many people beyond your immediate household could you turn to who would be willing to assist you? [1] No one; [2] One or two people; [3] Three or four people; [4] Five or more people

11.7. [If not zero] of those people, how many do you think are currently able to assist you?

11.8. [If not zero] Are most of these people of similar/higher/lower economic status? [1] Similar; [2] Higher; [3] Lower

\section{MODULE 12. WILLINGNESS TO PAY FOR COLLECTIVE SERVICES}

Scenario: Assume that FA aims to improve the services (quality seeds, internal controlling system) in order to bring benefit to its members. However, without membership fee and external support, FA could not cover all these costs. Suppose that FA board commitee seeks to get view before apply price for using their collective seeds.

12.1. If the price of seeds was introduce last crop season as 30.000 VND per kilogram,

- $\quad$ Are you willing to pay for it: [1] Yes; [2] No;

- Please indicate your perception on the price 1] Very low [2] Low [3] Average [4] High [5] Very high

- I do not know (code 99)

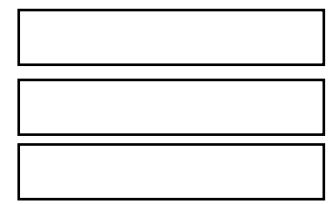

- Please indicate why you would not willingness to pay?

12.2. If you think that the price is too high, please suggest a figure by which price should be reduced to enable you to buy: VND

12.3 If you think that the price is too low, please suggest a figure by which price should be increased to enable you to buy: ------------ VND I can in good conscience recommend collective seeds to other farmers in the village [1] Yes; [2] No; 
Questionnaires

MODULE13. CONSUMPTION AND EXPENDITURE

\begin{tabular}{|c|c|c|c|c|c|c|c|c|c|}
\hline \multirow[b]{2}{*}{ ITEM } & \multirow[b]{2}{*}{ During last 7 days } & \multicolumn{2}{|c|}{$\begin{array}{c}\text { Quantity } \\
\text { consumed }\end{array}$} & \multicolumn{3}{|c|}{ How much came from purchases } & \multirow[b]{2}{*}{ ITEM } & & \multirow[b]{2}{*}{$\begin{array}{c}\text { Total expenditure } \\
\text { 1000VND }\end{array}$} \\
\hline & & Quantity & $\begin{array}{l}\text { Unit } \\
\text { Code } \\
\end{array}$ & Quantity & $\begin{array}{l}\text { Price/Unit } \\
\text { Code J } \\
\end{array}$ & $\begin{array}{c}\text { Total } \\
\text { expenditure } \\
\text { 1000VND } \\
\end{array}$ & & & \\
\hline & Staples & & & & & & & During last 30 days & \\
\hline 01 & Rice & & & & & & 18 & Salt & \\
\hline 02 & Sticky rice & & & & & & 19 & Sugar & \\
\hline 03 & Noodle & & & & & & 20 & Fish source & \\
\hline \multirow[t]{2}{*}{04} & Other staples (specify) & & & & & & 21 & Cooking oil & \\
\hline & Non-staple Fresh & & & & & & & Drinks & \\
\hline 05 & Beef & & & & & & 22 & Alcohol & \\
\hline 06 & Pork & & & & & & 23 & Beer & \\
\hline 07 & Chicken & & & & & & 24 & Tea and coffee & \\
\hline 08 & Fish & & & & & & 25 & Other (soda, mineral water) & \\
\hline 09 & Eggs & & & & & & & During last 365 days & \\
\hline \multirow[t]{2}{*}{10} & Inside (liver, stomach) & & & & & & 26 & Medicine/medical care & \\
\hline & Other products & & & & & & 27 & Transport costs & \\
\hline 11 & Fresh milk & & & & & & 28 & Clothing & \\
\hline 12 & Powder milk & & & & & & 29 & Education (fees, textbooks) & \\
\hline 13 & Vegetable & & & & & & 30 & Wedding and funeral & \\
\hline 14 & Fruits & & & & & & 31 & Remittance to relatives & \\
\hline 15 & Tofu & & & & & & 32 & Fees and contribution to local governments & \\
\hline 16 & Spicy (Onion, garlic, chili) & & & & & & 33 & Other contribution & \\
\hline 17 & Other (specify) & & & & & & 34 & Electric bill, gas, coal, wood & \\
\hline
\end{tabular}


List of Publications and Presentations

Refereed Conference Papers

Posters

Pham, T.T., Theuvsen, L., Otter, V. (2016), Collective Action Effects on Farm Productivity and Efficiency of Rice Producers in Vietnam. Contributed paper accepted for poster presentation at the Tropentag 2016 - "Solidarity in a competing world - fair use of resources", Vienna, Austria, September 19-21, 2016.

\section{Presentations}

Pham, T.T., Theuvsen, L., Otter, V. (2016), Determinants of Smallholder Farmers’ Marketing Choice: Evidence from the Rice Sector in Vietnam. Contributed paper accepted for presentation at the IFAMA 26th Annual World Conference - "Become the solution: Food Security 2050", Aarhus, Denmark, June 19-23, 2016.

Pham, T.T., Dao, T.A., Theuvsen, L. (2016), Determinants of Specialty Rice Adoption by Smallholder Farmers in the Red River Delta of Vietnam. Contributed paper accepted for presentation at the Agrarian Perspectives XXV - "Global and European Challenges for Food Production, Agribusiness and the Rural Economy”, Prague, Czech Republic, September 14-16, 2016 and has been published in the associated conference proceedings, pp. 259-67.

Pham, T.T., Theuvsen, L., Otter, V. (2016), Collective Action Effects on Technical Efficiency of Specialty Rice Farmers in Vietnam. Contributed paper accepted for presentation at the $3^{\text {rd }}$ GlobalFood Symposium, Göttingen, Germany, April 28-29, 2017. 


\section{Curriculum Vitae}

\section{Personal data}

Name:

Date of Birth:

Place of birth:

Nationality:

\section{Education}

6/2013 - now

$11 / 2006-11 / 2008$

$09 / 2000-6 / 2004$
PHAM, Thai Thuy

June 8, 1982

Phu Tho, Vietnam

Vietnamese
PhD student, research assistant, Department of Agricultural Economics and Rural Development, Faculty of Agricultural Science, University of Goettingen, Germany; RTG 1666 GlobalFood.

Master of Economics, Hanoi University of Agriculture, Vietnam

Bachelor of Agricultural Economics, Hanoi University of AgricultureNo.1, Vietnam.

\section{Working experience}

6/2013 - now

2009- 5/2013

$2007-2009$

$2004-2006$
Department of Agricultural Economics and Rural Development, Faculty of Agricultural Sciences, University of Goettingen, Germany. RTG 1666 GlobalFood.

Hung Vuong University, Department of economics and business. Lecturing in: Theory of economics, agricultural economics, econometrics and economic mathematical models. Address: Nong Trang- Viet Tri Phutho.

Freelance-Consultant, Institute of Policy and Strategy for Agriculture and Rural Development (IPSARD), Rural Development Center (RUDEC), Researcher. Main duties: Conduct researches on community development, rural development, and farmer organizations.

Vietnam Agricultural Science Institute (VASI), Agrarian Systems Department, Researcher. Main duties: Conduct researches on rural economics, agricultural commodity chain, and Designation of Origin. 